Portland State University

PDXScholar

Summer 9-2-2015

\title{
Hydrogeologic Investigation of a Pumice Aquifer, Fremont/Winema National Forest, Oregon
}

Jonathan Michael Weatherford

Portland State University

Follow this and additional works at: https://pdxscholar.library.pdx.edu/open_access_etds

Part of the Geology Commons, and the Hydrology Commons

Let us know how access to this document benefits you.

\section{Recommended Citation}

Weatherford, Jonathan Michael, "Hydrogeologic Investigation of a Pumice Aquifer, Fremont/Winema National Forest, Oregon" (2015). Dissertations and Theses. Paper 2479.

https://doi.org/10.15760/etd.2476

This Thesis is brought to you for free and open access. It has been accepted for inclusion in Dissertations and Theses by an authorized administrator of PDXScholar. Please contact us if we can make this document more accessible: pdxscholar@pdx.edu. 
Hydrogeologic Investigation of a Pumice Aquifer,

Fremont/Winema National Forest, Oregon

\author{
by \\ Jonathan Michael Weatherford
}
A thesis submitted in partial fulfillment of the requirements for the degree of
Master of Science
in
Geology

Thesis Committee:

Michael L. Cummings, Chair

Robert B. Perkins

John Bershaw

Portland State University

2015 


\begin{abstract}
The middle Holocene cataclysmic eruption of Mount Mazama blanketed Walker Rim, in south central Oregon, with $270 \mathrm{~cm}$ to $300 \mathrm{~cm}$ of pumice, causing capture of surface water systems by groundwater, stream relocation, and the formation of biologically diverse fens and seasonal wetlands. The pumice aquifer at Round Meadow, an $8.6 \mathrm{~km}^{2}$ basin, hosts both a fen and seasonally ponded wetlands. The Round Meadow watershed lies within a closed basin between the upper Klamath and Deschutes river basins. As the highest meadow at Walker Rim, it is a relatively well-constrained system to study the effects of hydrological disruption.
\end{abstract}

A water budget was calculated for the basin, hydraulic conductivity was evaluated for the three main sediment layers in the meadow, recharge sources and evaporative trends were studied using stable isotope analysis, and aquifer residence times were estimated using CFC tracer water age dating. Water year 2014 was a drought year and observation of the system under stressed conditions allowed discrimination of four independently functioning components of the hydrogeologic system. These were the meadow, which is by far the largest component in terms of water storage, the fen where iron cementation and up to $1 \mathrm{~m}$ of peat holds water in a berm above the meadow, three springs which are sourced from deeper groundwater hosted in the bedrock which underlies the pumice deposit, and the outflow area. In all cases, the aquifer material is pumice, but the influence of the pre-eruption landscape and post- 
eruption modifications of the aquifer material have resulted in partial isolation of the components.

The water budget analysis indicated that the basin lost $44 \mathrm{~cm}$ of water storage during WY 2014. Hydraulic conductivity values of $1 \times 10^{-6}, 2 \times 10^{-2}$, and $4 \times 10^{-5} \mathrm{~cm} / \mathrm{s}$, were determined for the diatomaceous silt underlying the pumice, the Plinian pumice fall aquifer, and for the diatomaceous silt overlying the pumice, respectively. The pumice is characterized as a perched, weakly confined aquifer and residence times in the pumice are much longer (decades) than for water near the surface of the meadow. Water discharging at the springs is isotopically different (lighter) than either the surface water or groundwater in the pumice aquifer. The fen at Round Meadow appears dependent on seasonal precipitation to recharge water, and responds to fluctuations in annual precipitation. The wetland meadows are volumetrically the main water-storing features at Round Meadow, and these are not homogenous features, but a combination of discrete components. 


\section{Dedication}

The work that was put into producing this thesis is dedicated to the memory of my cousin Sara Deborah Weatherford, educator and mom. The results of my research are dedicated to the past, current and future inhabitants of the Klamath River basin. 


\section{Acknowledgements}

I would like to acknowledge my committee and the Portland State University Department of Geology for their input and support on this project. In particular I am indebted to Mike Cummings for his insights into the hydrogeology of the region, his advice on the writing and sharing of my research and, for his enthusiasm and good humor over the past years. Finally, I want to thank my wife Grace and my sons Colin and Theodore for their patience, love and support. 


\section{Contents}

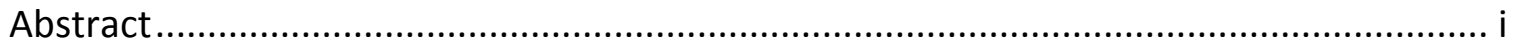

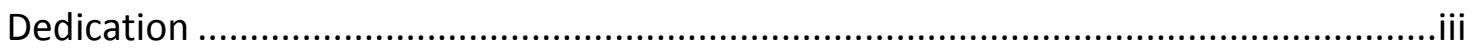

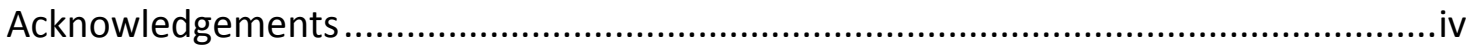

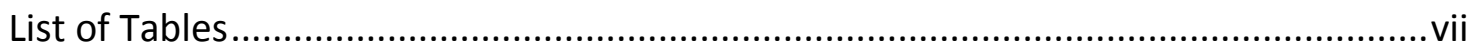

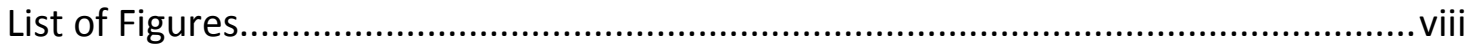

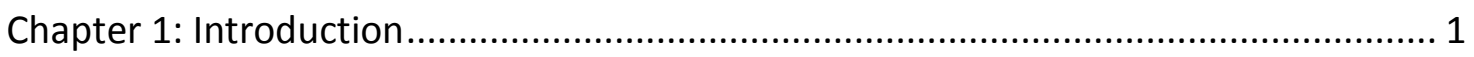

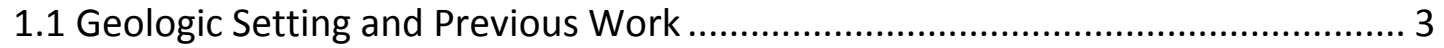

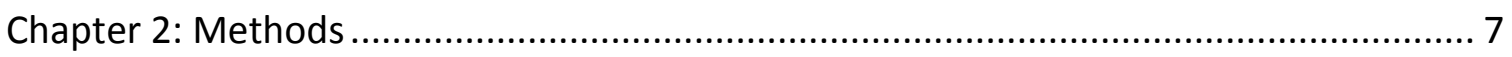

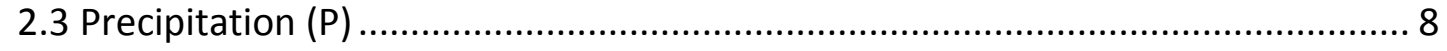

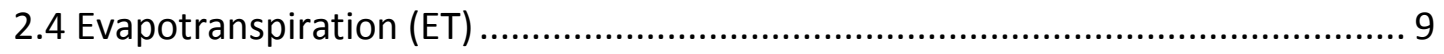

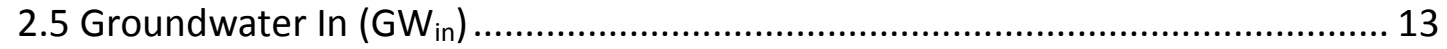

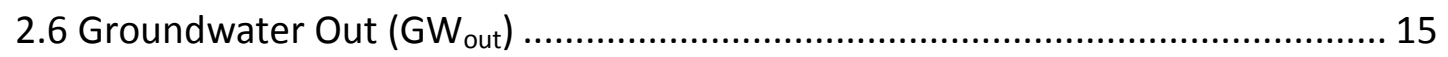

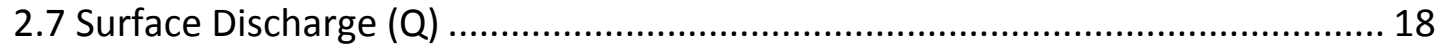

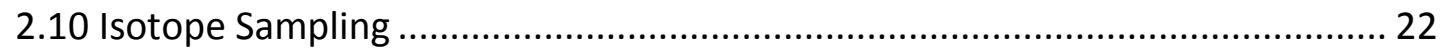

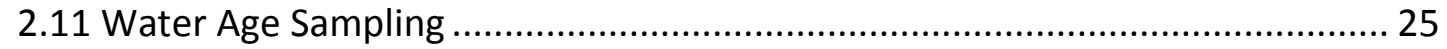

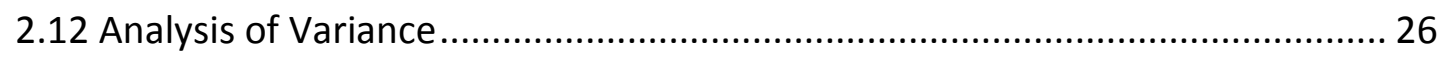

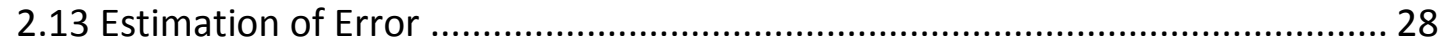

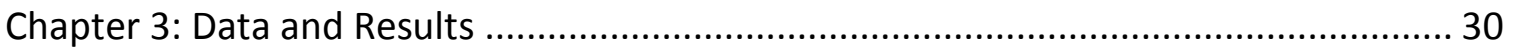

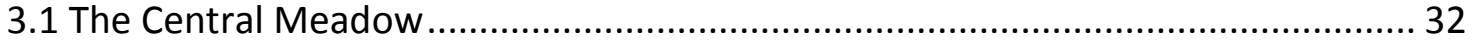

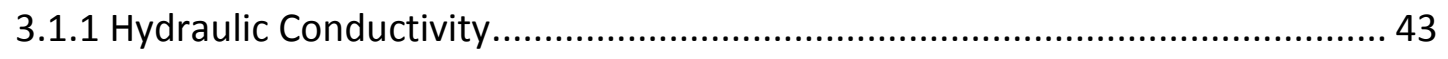

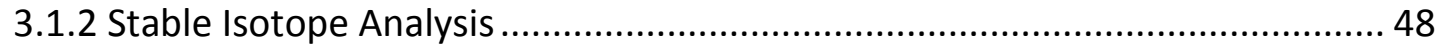

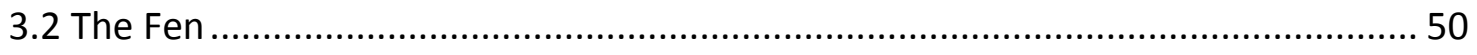

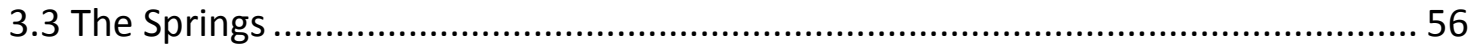

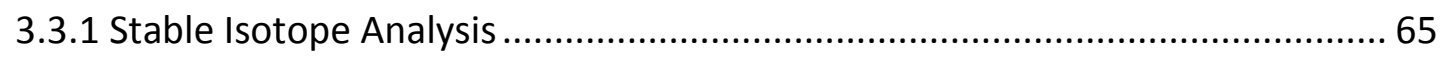

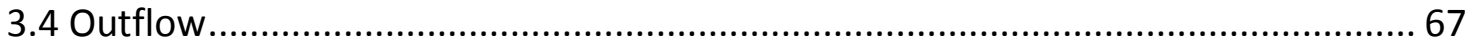

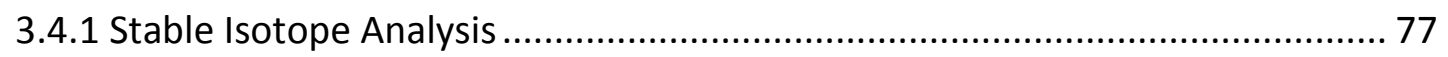




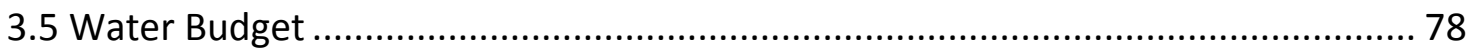

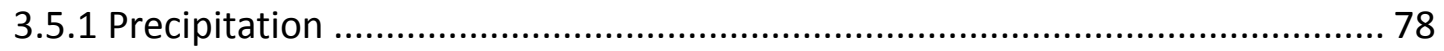

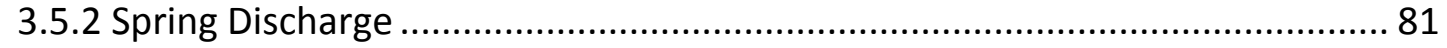

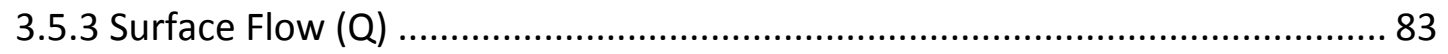

3.5.4 Evapotranspiration .................................................................................... 85

3.5.5 Groundwater Flow.................................................................................... 88

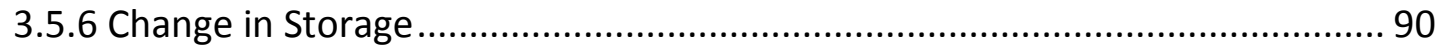

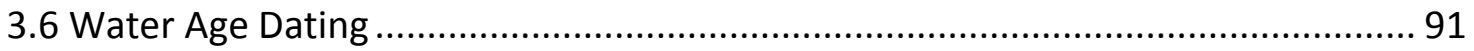

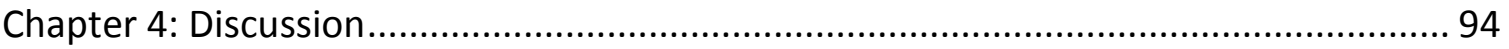

4.1 Evolution of post-eruption Round Meadow ....................................................... 94

4.2 Hydrogeologic components of the Round Meadow basin.................................. 96

4.2.1 The Central Meadow ........................................................................................ 97

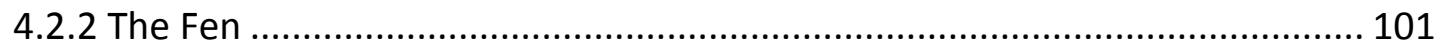

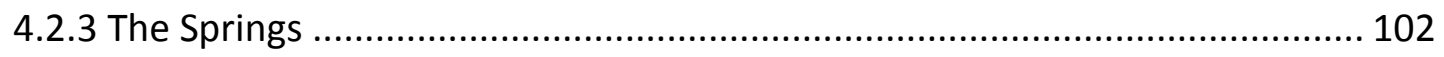

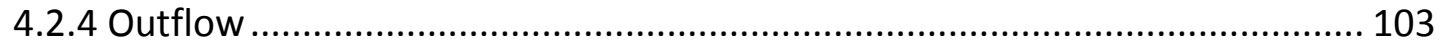

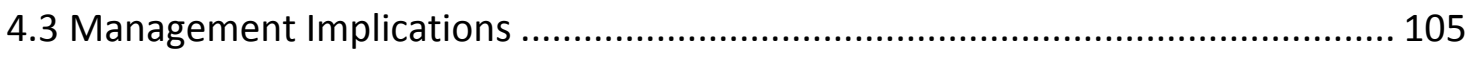

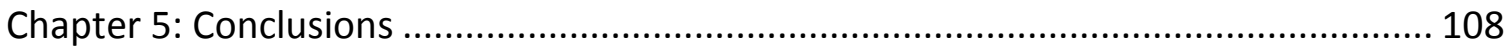

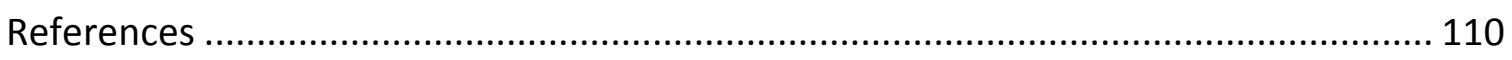

Appendix A: Water Level Measurements .............................................................. 114

Appendix B: Discharge measurements ............................................................... 115

Appendix C: Relative Elevations of piezometers and springs .................................... 116

Appendix D: Stable Isotope Data ....................................................................... 117

Appendix E: Core Logs ................................................................................... 118 


\section{List of Tables}

Table 1: Stable isotope sampling location listed by date

Table 2: Instrument and model uncertainty for meteorological measurements and stream gaging...

Table 3: Relative elevations of 6 piezometers in Round Meadow

Table 4: Hydraulic conductivity and groundwater velocity for 3 sediment types at Round

Meadow . .44

Table 5: Mean and standard deviations for isotope data from springs, piezometers and surface water 49

Table 6: Coefficents of variation for spring discharge and flow in Sellers Creek .63

Table 7: Discharge and flow rate measurements for 3 springs and Sellers Creek .83

Table 8: Average evapotranspiration for Round Meadow and 3 Agrimet stations 87

Table 9: Water age dates from 4 chemical tracers. 


\section{List of Figures}

Figure 1 Regional map of study area.......................................................................

Figure 2 General stratigraphy of the northern meadow.............................................4

Figure 3: Map of sampling locations for isotope analysis........................................23

Figure 4: Precipitation for current water year, prior water year (WY2014), historical range, and expected values from the period of record.............................31

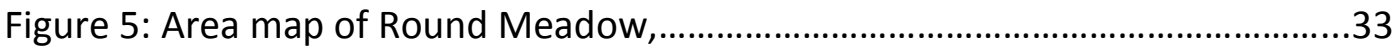

Figure 6: Cross section of central Round Meadow......................................................35

Figure 7: Photograph of the vibracore sample from Round Meadow......................36

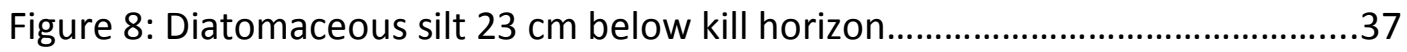

Figure 9: Diatomaceous silt $40 \mathrm{~cm}$ below modern ground surface...........................39

Figure 10: Hydrographs from WY 2011 to WY 2015 for 3 piezometers in Round

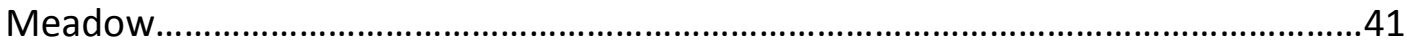

Figure 11: Pressure transducer and temperature data for 2 piezometers...............46

Figure 12: Grain size analysis for the 3 main depositional units in Round

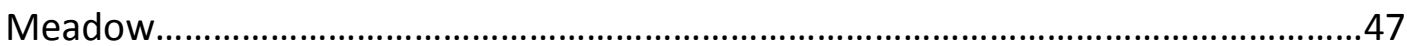

Figure 13: Isotopic ratio data for the springs, piezometers, and main canal...........50

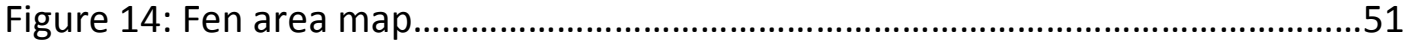

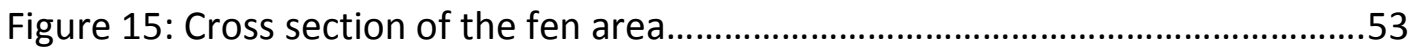

Figure 16: Hydrograph for the fen area piezometers................................................55

Figure 17: Area map of springs in Round Meadow.....................................................57

Figure 18: Photograph of pine tree spring .................................................................59

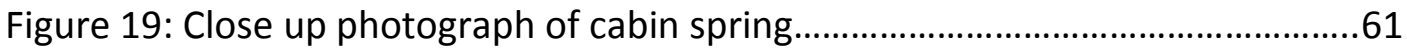

Figure 20: Measured discharge of the 3 springs compared to Sellers Creek...........63

Figure 21: Temperature measurements from April to October 2014......................64

Figure 22: Conductivity measurements from April to October 2014.......................65

Figure 23: Results of isotopic analysis for the Round Meadow and 460 fen

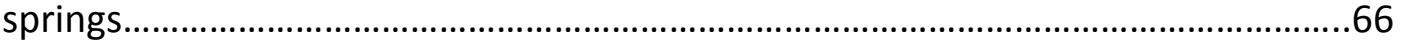

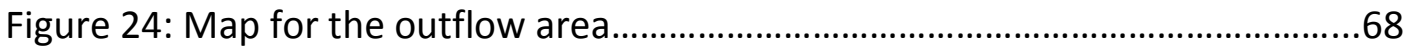

Figure 25: Water pressure in the vibracore piezometer..........................................70

Figure 26: Cross section of the outflow area..............................................................72

Figure 27: Flow rates for Sellers Creek north of the outlet spring and at the

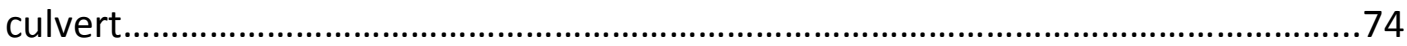

Figure 28: Hydrograph for the confluence and outlet piezometers.........................76

Figure 29: Isotopic ratios for ground water and surface water samples....................78 
Figure 30: Cumulative and daily precipitation from WY 2014...................................80

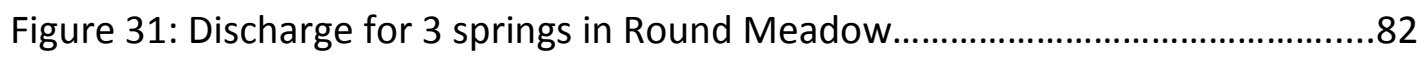

Figure 32 Plot of precipitation, temperature, and snow depth ................................84

Figure 33: Discharge and flow rates for the outlet spring and Sellers Creek............85

Figure 34: Daily evapotranspiration at Round Meadow...........................................86

Figure 35: Potentiometic maps of groundwater head.............................................89

Figure 36: A conceptual model of recharge of storage in the pumice aquifer.......100 


\section{Chapter 1: Introduction}

The Holocene eruption of Mount Mazama in the Oregon Cascade range blanketed Walker Rim (Figure 1), an uplifted fault block in the Fremont/Winema National Forest northeast of the volcano, with 270 to $300 \mathrm{~cm}$ of pumice (Young, 1990; Bacon and Lanphere, 2004). The subaerial inundation of the pre-eruption landscape disrupted the surface- and groundwater systems resulting in flooding and failure of debris dams, channel and floodplain relocation, transfer of surface flow to groundwater storage, and formation of wetlands and fens (Cummings, 2007; Cummings and Conaway, 2009; Cummings et al., 2014). In the modern environment, the pumice layer is a weakly confined perched aquifer which in the meadows of the Walker Rim area is commonly associated with shallow-slope fens marked by thriving wetland plant species and high biodiversity (Aldous and Gurrieri, 2011; Cummings et al., 2014). Round Meadow is the highest fen-hosting meadow in the region and it is a relatively wellconstrained basin in which to investigate water resources available at Walker Rim, the hydrologic properties of this unusual aquifer material, and the response of the surfaceand groundwater systems to volcanic disruption. 


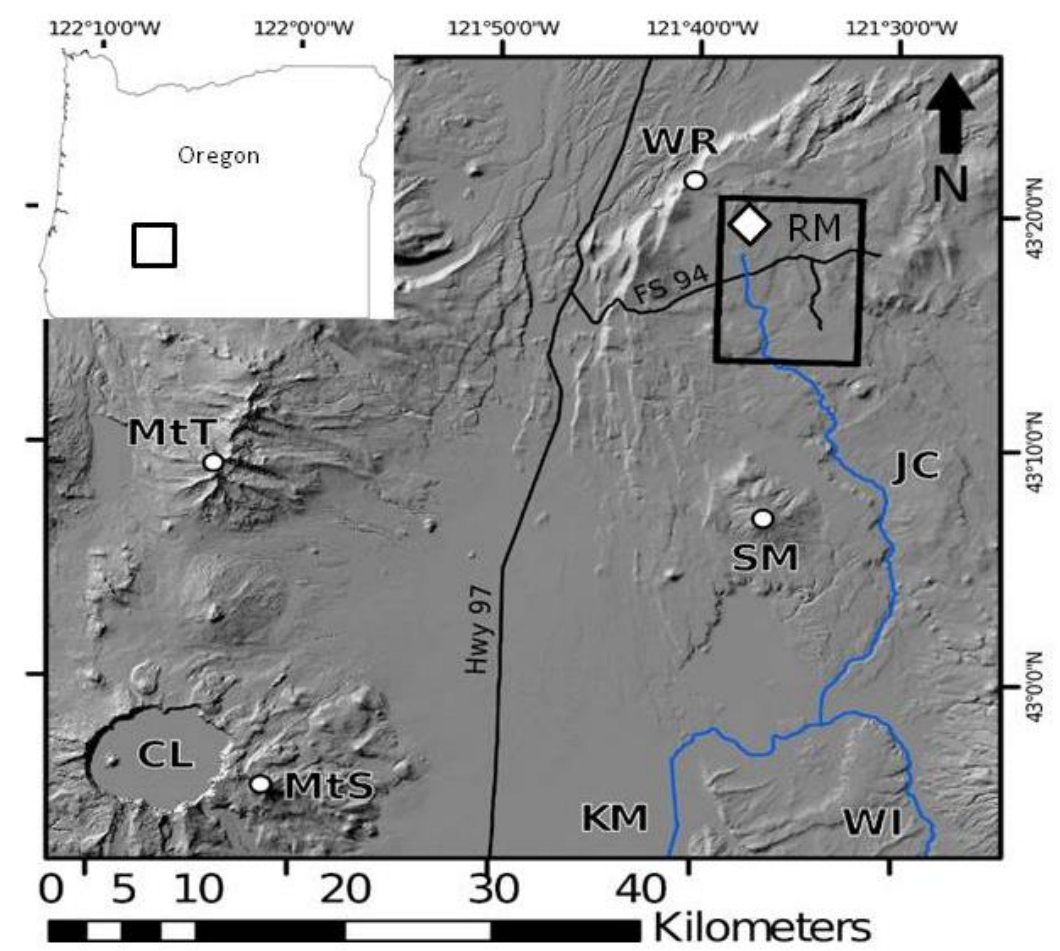

Figure 1 Regional map of study area. CL: Crater Lake, MtS: Mt Scott, MtT: Mt Thielsen, KM: Klamath Marsh, WI: Williamson River, SM: Sugarpine Mountain, JC: Jack Creek, WR: Walker Rim, RM: Round Meadow

Water budgets based on mass balance are a well-established method for quantifying resources and characterizing the hydrologic parameters of a basin (Winter, 1999; Gannett et al., 2001; Janssen and Cummings, 2007) and a water budget has been calculated for the Round Meadow catchment. Isotopic ratios for ${ }^{18} \mathrm{O}$ and ${ }^{2} \mathrm{H}, \mathrm{CFC}$ water age dating, hydrochemistry, and water level monitoring in an array of piezometers were used to elucidate and support the parameters used in the water budget. Although these methods have been widely used in hydrologic investigations, studies on pumice aquifers are scarce, and the transmissivity and storativity of this unusual material and the hydrologic response of young volcanic landscapes are not well understood. 
The complexity of natural systems including multiple sources and sinks of water within a basin, and heterogeneities in the subsurface which control groundwater flow pose significant challenges in establishing a well constrained water budget (Gannett et al., 2001). Round Meadow was selected because the catchment presents several distinct advantages in overcoming these obstacles. At $1710 \mathrm{~m}$ elevation, the meadow is the highest in the region and precipitation falling within the watershed is the main water input to the system. There is a single outlet channel that runs due north from the northeast corner of the meadow and all streamflow that leaves the meadow runs through this channel. Most importantly, because the pumice was deposited as a blanketing unit in airfall from the Plinian eruption, the aquifer is effectively isotropic and homogenous within the pumice, which allowed a more accurate approximation of storage and flow within the aquifer.

\subsection{Geologic Setting and Previous Work}

Walker Rim is in the rain shadow of the Cascade Range, about $70 \mathrm{~km}$ northeast of ancestral Mount Mazama (modern Crater Lake). The bedrock is comprised of basalt lava flows, a rhyolitic welded tuff, and volcaniclastic sedimentary rocks. Figure 2 contains a generalized stratigraphic column for the Round Meadow area. The age of the phenocryst-poor welded tuff that crops out at the northern margin of Round Meadow is inferred to be Pliocene based on geochemical correlation to trachy dacite to rhyolite domes exposed in the Klamath Marsh area, $56 \mathrm{~km}$ to the south. Stratigraphically above the welded tuff is weakly indurated, diatomaceous siltstone. The contact relations 
between the welded zone of the welded tuff and the diatomaceous siltstone are not known. As suggested in Figure 2 the diatomaceous siltstone overlies an unwelded carapace breccia associated with the welded zone of the tuff. The welded tuff and the diatomaceous siltstone are important hydrogeologic units and will be discussed below.
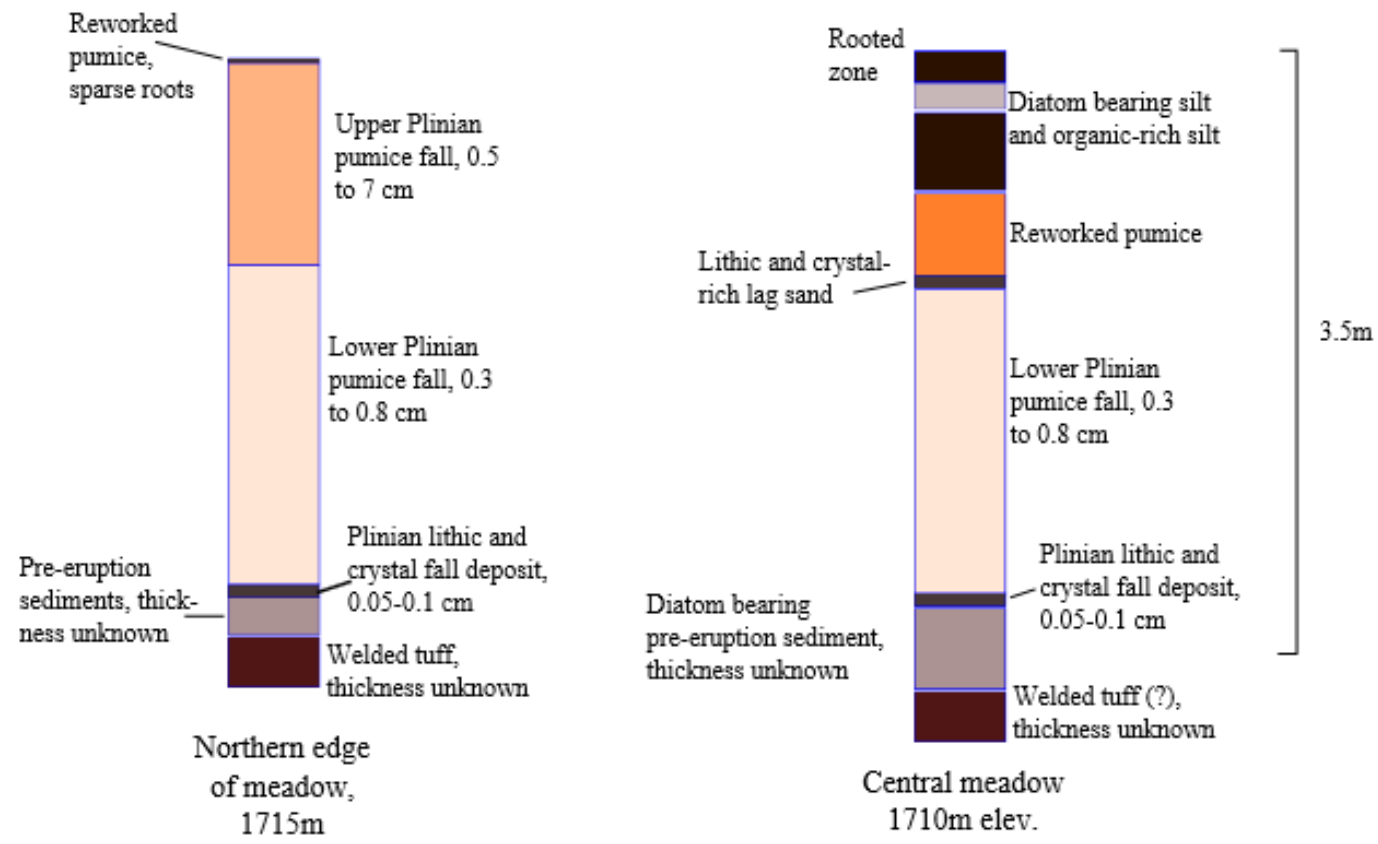

Figure 2 General stratigraphy of the northern meadow at $1715 \mathrm{~m}$ and the central meadow at $1710 \mathrm{~m}$. Actual thicknesses of the pre-eruption sediment and the welded zone of the tuff are unknown. The tuff is inferred to be lower in the central meadow based on the shallow southward dip of the welded tuff at the northern side.

Pumice fallout from the cataclysmic Mazama eruption was deposited on a paleosol developed on the relatively low permeability, weakly indurated, diatomaceous siltstone in Round Meadow. The pumice is divided into upper and lower units based on composition, grain size and sorting. The base of the unit is marked by a sharp contact with a 3-5 cm thick layer of well sorted crystal- and lithic-rich sand. This is overlain by 
$1.5 \mathrm{~m}$ of crystal- and lithic-bearing moderately well-sorted pumice that increases upward in grain size from 0.3 to $0.8 \mathrm{~cm}$. The upper pumice unit is $1 \mathrm{~m}$ of poorly sorted vertically undifferentiated lapilli to blocks 0.5 to over $7 \mathrm{~cm}$, with sparse phenocrysts and lithics. These lower and upper units are a sub-division of the upper pumice described by Young (1990), but the lower pumice of Young is not found at Round Meadow. While the entire pumice section is found on slopes surrounding Round Meadow, within the meadow all or part of the upper pumice is absent and in its place there are up to $1.2 \mathrm{~m}$ of silt and vitric silt with sub-angular pumice sand (Figure 2).

The fens at Wilshire, Dry, Johnson and Round Meadows in the Antelope Grazing Allotment were studied by The Nature Conservancy and U. S. Forest Service (Aldous and Gurrieri, 2011) using nested piezometers and monitoring wells. They focused their study to the relatively small area of the fens themselves, and to the peat layer that overlies the pumice. The study concluded that the modern fens are the sites of pre-eruption springs where the water moved through the pumice and induced plant production which formed the peat. Dr. Michael Cummings and students from Portland State University Department of Geology have studied Round Meadow seasonally since 2011, and installed the piezometers outside the fen. That work has described the bedrock and unconsolidated sediments in the area through field observations and auger borings, but has not attempted to quantify water fluxes in the aquifer. The behavior of pumice in water has been described (Manville et al., 1998) to characterize the geomorphic effects of the Taupo eruptions in New Zealand, but has not been examined as a water-storing 
unit. The Mazama pumice has been studied to evaluate the vesicularity and structure of the pumice (Klug et al., 2002), but the saturation properties of the pumice were not addressed.

Several techniques were employed in the hydrological investigation of the system at Round Meadow, but all of the techniques were planned and carried out with 3 motivating questions in mind. First, how much water is present and bioavailable on Walker Rim to support livestock grazing and the fen ecosystem? Second, how do the unusual properties of pumice affect the storage and transport of water in the pumice aquifer? Finally, how can the system at Round Meadow elucidate and inform our understanding of landscape response to volcanic inundation? 


\section{Chapter 2: Methods}

\subsection{Watershed Delineation}

The area of the watershed that is drained by Sellers Creek at the point it crosses under FS 9405 at UTM 612005 E, 4799547 N (Zone 10T) was found using ESRI's ArcGIS Hydro tool and a Digital Elevation Model (DEM). The DEM was created from LiDAR downloaded from and originally collected by Watershed Sciences Inc. with an average pulse spacing of $0.35 \mathrm{~m}$ (http://earthexplorer.usgs.gov/, accessed April 2015). Delineating a watershed from DEM requires a sequence of steps that allow ArcGIS to calculate direction of flow for each $1 \times 1 \mathrm{~m}$ cell on the map. In the first step, any sinks or areas where either the resolution of the DEM or the local topography creates a no-flow spot are digitally filled so that every cell can be hydraulically linked to its 8 neighbors. In the second step, the flow direction uses this filled map in which each cell was assigned an integer value from 1 to 255 based on relative elevation and generated a new raster where direction of flow is determined based on slope. In the final step, a pour point was designated on this new raster (the culvert at FS 9405) and the watershed tool iteratively calculated all of the cells that would connect to flow past this point. The watershed was then converted to a polygon, and the area was found using the calculate geometry tool. These computed values were checked using topographic maps and field observations in and around Round Meadow. 


\subsection{The Water Budget}

The water budget in its basic form is simply expressed by the mass balance equation

$$
\text { Input }- \text { Output }=\Delta \text { Storage }
$$

in which the Input and Output terms can usefully be separated into

$$
\left(P+Q_{\text {in }}+G W_{\text {in }}\right)-\left(E T+Q+G W_{\text {out }}\right)=\Delta S
$$

where $\mathrm{P}$ is precipitation, $\mathrm{GW}_{\text {in }}$ is groundwater input, $\mathrm{ET}$ is evapotranspiration, $\mathrm{Q}$ is surface discharge, and $\mathrm{GW}_{\text {out }}$ is groundwater output. The methods for measuring and constraining each of these fluxes are discussed individually below.

\subsection{Precipitation (P)}

\section{Weather Station and SNOTEL}

A Spectrum Watchdog 2700 meterological station was installed 19-April-2014 in Round Meadow $2 \mathrm{~m}$ above local ground surface at the northern side of the meadow. The site was selected to be far enough from the center of the meadow that it would be accessible even when the meadow was inundated with water, yet approximately $50 \mathrm{~m}$ from the nearest trees to reduce wind fetch (Vallet-Coulomb et al., 2001). Every 30 minutes the station recorded temperature, relative humidity, wind speed, wind direction, shortwave solar radiation, and precipitation. The meterological data were downloaded monthly. On 26-May-2014 the pyranometer and rain gauge were disabled 
by an animal. The damage was discovered on 14 -June-2014, but could not be repaired at that time. On 12-July-2014 the pyranometer was replaced, but the rain gauge could not be repaired. Incoming solar radiation from 26-May to 21-June-2014 was estimated by finding the slope of a linear trendline for all pyranometer data for the 10 days prior to disabling, and from 22-June to 12-July-2014 the slope for the data for the 10 days after 12-July-2014 were used. It was assumed that 21-June-2014 would represent an inflection point for solar radiation coinciding with the solstice. Precipitation data for the project were downloaded from the Chemult Alternate Snotel station (http://www.wcc.nrcs.usda.gov/nwcc/site?sitenum=395, accessed January, 2015) located about $18 \mathrm{~km}$ southwest of Round Meadow and $230 \mathrm{~m}$ lower. Since the Round Meadow basin is higher in elevation, it likely received more water due to orographic precipitation and the Oregon State University PRISM (Parameter-elevation Regressions on Independent Slopes Model) data were used to estimate the variation (http://www.prism.oregonstate.edu, accessed March, 2015).

\subsection{Evapotranspiration (ET)}

\section{Penman Equation and Methods}

A Penman method was used to calculate evapotranspiration from April to October in Round Meadow. This method combines terms for mass transfer and energy balance and is considered one of the best tested and most reliable ways to approximate evapotranspiration (Winter et al., 1995). The equation can be written in various forms, but it has been derived from its component parts by Dingman (2002, p. 286) in the form 


$$
E T=\frac{\Delta(K+L)+\gamma * K_{E} * \rho_{w} * v_{a} * e_{a}^{*}\left(1-W_{a}\right)}{\rho_{w} * \lambda_{w}(\Delta+\gamma)}
$$

in which $\Delta$ is the slope of the temperature/pressure curve defined by the equation

$$
\Delta=\frac{\partial e^{*}}{\partial T}=\frac{2508.3}{(T+237.3)^{2}} * \exp \left(\frac{17.3 * T}{T_{s}+237.3}\right)
$$

where $\Delta$ is in $\mathrm{KPa} / \mathrm{K}$ and temperature is in degrees $\mathrm{C} . \mathrm{K}$ is the net incoming shortwave radiation found through

$$
K=K_{\text {in }} *(1-a)
$$

where $\mathrm{K}_{\text {in }}$ was measured by the pyranometer in $\mathrm{MJ} /$ day and $a$ is the albedo, a unit-less number based on the ratio of radiation that is reflected or absorbed by the regional ground surface. For Round Meadow the albedo was estimated from empirically derived values at 0.25 for a mix of wet and dry grass coverage (Dingman, 2002).

The $L$ value is the net longwave radiation, estimated by the relation

$$
L=\varepsilon_{w} * L_{a t}-\varepsilon_{w} * \sigma(T+273.2)^{4}
$$

in which $\varepsilon_{\mathrm{w}}$ is the emissivity of water, 0.98 , and $\sigma$ is the Stefan-Boltzmann constant, $4.9 * 10^{-9} \mathrm{MJ} / \mathrm{m}^{2}$ day. $\mathrm{L}_{\mathrm{at}}$ is the incoming longwave flux, which can be approximated by

$$
L_{a t}=\varepsilon_{a t} * \sigma(T+273.2)^{4}
$$

and $\varepsilon_{\text {at }}$ is the effective emissivity of the atmosphere, primarily a function of humidity which was estimated by the equation 


$$
\varepsilon_{a t}=1.72 *\left(\frac{e_{a}}{T+273.2}\right)^{1 / 7}
$$

where $e_{a}$ is vapor pressure, a function of temperature and relative humidity given by the relation

$$
e_{a}=W_{a} * e_{a}^{*}
$$

and $e_{a}{ }^{*}$ is the saturation vapor pressure, a function of temperature found through

$$
e_{a}^{*}=0.611 * \exp \left(\frac{17.3 * T}{T+237.3}\right)
$$

The variable $\lambda$ represents latent heat of evaporation for water, $2.495 \mathrm{MJ} / \mathrm{kg}$. This value varies with temperature, however, and for the Penman calculation $\lambda$ was given by

$$
\lambda=2.495-\left(T * 2.36 * 10^{-3}\right)
$$

for the measured temperature in degrees $C$ at each time step. The psychrometric constant, $\gamma$, was calculated by

$$
\frac{c_{a} * P}{0.622 * \lambda}
$$

in which $c_{a}$ is the heat capacity for air, $1.00 * 10^{-3} \mathrm{MJ} / \mathrm{kg}$, and $\mathrm{P}$ is pressure, estimated at $850 \mathrm{KPa}$ based on the elevation of Round Meadow. $\mathrm{K}_{\mathrm{E}}$ is a coefficient for wind velocity which represents the capacity for vertical transport of water. It is dependent on height of measured wind velocity and the roughness of the ground surface as can be seen in the relation 


$$
K_{E}=\frac{0.622 * \rho_{a}}{P * \rho_{w}} * \frac{1}{\ln \left[\left(\frac{z_{m}-z_{d}}{z_{0}}\right)\right]^{2}}
$$

where $z_{m}$ is the height at which wind velocity was measured, $z_{d}$ is the zero plane displacement, and $z_{0}$ is the roughness height of the ground surface. In most experiments, $z_{m}$ is a constant, and $z_{d}$ and $z_{0}$ are used to adjust for unusual evaporative conditions such as warm air trapped over snow. It has been found that for stable conditions over planted or saturated surfaces $K_{E}$ is well approximated by the equation

$$
K_{E}=1.69 * 10^{-5} * A^{-0.05}
$$

where $A$ is the area of the study in $\mathrm{km}^{2}$ (Harbeck, 1972; Dingman, 2002).

The Penman method assumes a well-watered surface to approximate the effective transfer of moisture. The water table near the weather station had dropped to $50 \mathrm{~cm}$ below local ground surface on 12-July-2014. A study on evapotranspiration indicated that the Penman method was applicable with water table depths of up to 30 cm (Souch et al., 1998). Another study in the nearby Wood River valley measured evapotranspiration in adjacent irrigated and non-irrigated fields and found that starting in mid-July evaporative efficiency dropped $40 \%$ by the end of the water year (Cuenca et al., 2005). Beginning on 12-July-2014 a gradual reduction in evapotranspiration was applied over the area of the watershed to reach a $40 \%$ lower transfer rate by the end of WY 2014. This may have introduced some error in the calculation. The results of this 
project indicated that the water table may have been lower in parts of the watershed, but this was not directly measured in the water budget.

\subsection{Groundwater In (GW in $)$}

\section{Spring Gaging}

Discharge from 2 springs flowing into Round Meadow and one spring flowing into Sellers Creek was gaged using a Swoffer model 2100 current velocity meter and top set wading rod. The springs and creek were gaged monthly from April to October, 2014 at the locations listed below (data in Appendix B). During each measurement the velocity was measured 10 times at 1 -second intervals and then averaged. The westernmost, or pine tree spring was gaged at UTM $611202 \mathrm{E}, 4798914 \mathrm{~N}$. The cabin spring was gaged at UTM $611646 \mathrm{E}, 4798853 \mathrm{~N}$ near the spring orifice in June, and in a channel about $70 \mathrm{~m}(611543 \mathrm{E}, 4798748 \mathrm{~N})$ from the spring in July-October. Visual observations were that water inputs other than the spring in this distance were negligible. The gaging locations for these two springs were selected where the channels were defined by distinct banks and free of vegetation in the channel. In most cases, the depth of the water column was approximately the diameter of the propeller and the width of the channel was a few $\mathrm{cm}$ wider than the propeller diameter. As a result, discharge was measured at a single point with the propeller diameter controlling depth in the water column. The outlet spring flows over bedrock near the orifice and discharge could not be measured directly at the spring. Instead flow was measured in the stream channel immediately upstream and downstream of where the discharge from the 
springs entered Sellers Creek (611852 E, 4799155 N and 611854 E, 4799144 N) about 5 $\mathrm{m}$ from the spring orifices. The difference in discharge at the two sites was calculated as discharge from the spring. The dimensions of the channel at each location were remeasured every month to account for sedimentation in the channel or variations in the gaging location. The banks of the channel were abrupt and depth of the water column varied within a few centimeters. The channel width at the gaging point above the springs was $59 \mathrm{~cm}$. Therefore, depth of the water column was measured at $15 \mathrm{~cm}, 30$ $\mathrm{cm}$, and $45 \mathrm{~cm}$ from the west bank. At the gaging point below the spring the channel was about $90 \mathrm{~cm}$ across and depth was measured at $20 \mathrm{~cm}, 45 \mathrm{~cm}$, and $70 \mathrm{~cm}$ from the western bank. Early in the season vegetation prevented gaging near the banks and only the center velocity was measured. Velocity was measured at the same locations at approximately $10 \mathrm{~cm}$ deep within the water column. Discharge was calculated by

$$
Q=v A
$$

where $v$ is velocity in $\mathrm{m} / \mathrm{s}$ and $A$ is channel area in $\mathrm{m}^{2}$.

\section{Water Parameters}

Fourteen piezometers were installed at Round Meadow by Portland State University geology students and faculty from 2010 to 2014. Measurements of water parameters at Round Meadow were taken in these piezometers or on surface water by Portland State University geology students commonly accompanied by Michael Cummings or by the author. Temperature, conductivity, $\mathrm{pH}$, and oxidation-reduction 
potential (ORP) were measured using Vernier stainless steel temperature probes, Vernier conductivity probe, Vernier pH sensor, and Vernier ORP sensors. Depth to water table in the piezometers was calculated by dropping a weighted cord in the pipe and measuring the total depth of the hole, depth to water, and the height of the pipe above the ground surface. Additionally, Onset pressure transducers were placed at the bottom of 2 piezometers - vibracore (UTM $611865 \mathrm{E}, 4798787 \mathrm{~N}$ ) and eastbank (UTM $612218 \mathrm{E}$, $4798560 \mathrm{~N}$ ) to measure and record water levels every 30 minutes beginning in July, 2014 at those locations.

\subsection{Groundwater Out (GW out $)$}

\section{Finding Hydraulic Conductivity}

Three separate methods were used to estimate hydraulic conductivity of the primary pumice aquifer, in situ slug tests, laboratory permeameter tests, and grain size analysis. In August 2014 a temporary piezometer was installed about 10 m southwest of the vibracore piezometer at (611862 E, $4798786 \mathrm{~N})$. It was screened at $210 \mathrm{~cm}$ below local ground surface in pumice that were visually assessed to be the lower pumice unit (moderately sorted pumice 1-3 mm in diameter and moderately well-sorted, lithic fragments and crystals). The water table at the vibracore piezometer and the temporary piezometer before testing was measured at $77 \mathrm{~cm}$ below local ground surface. Each pipe was filled until the water reached $40 \mathrm{~cm}$ below ground surface, and then water levels 
were measured every 2 minutes until $90 \%$ of the added water had drawn down, according to the Hvorslev method. For the test, both piezometers were screened with hand-sawn slits near the base and open at the bottom of the pipe. The solution to the Hvorslev method for calculating hydraulic conductivity based on drawdown in a slug test is dependent on this geometry of the opening in the well or pipe and the relation

$$
K=\frac{2 \pi R}{11\left(t_{2}-t_{1}\right)} * \ln \left(\frac{H_{1}}{H_{1}}\right)
$$

for an open-bottom pipe (Schwartz and Zhang, 2003).

A sample of the pumice and lag sand from the hole that was dug for the slug test was brought back to the soil laboratory at Portland State University and tested in a Ward's constant head permeameter. The permeameter was allowed to run for approximately 10 minutes until a constant head was established and visually steady flow in the column was reached. A beaker was placed below the column and allowed to fill for 60 seconds, then the mass of the water in the beaker was measured. This test was repeated 10 times and the hydraulic conductivity was found by modifying Darcy's Law to the form

$$
K=\frac{Q L}{A t h}
$$

where $Q$ is the volume of water, $L$ is the length of the sediment column, $A$ is the crosssectional area of the column, $\mathrm{t}$ is time, and $\mathrm{h}$ is the hydraulic head from the base of the column to the water level. The same sample was then sieved through a stack of \#4,\#10, 
$\# 16, \# 20, \# 70, \# 120$, and \#230 ASTM size sieves. Roughly half of the sample remained on the \#70 sieve, so this portion was separated and re-sieved through a stack of \#30, \#50, and then \#70 sieves. The amount of sediment remaining on each sieve was weighed and divided by the total sample mass to determine the percent passing each opening by weight. The Hazen method for empirically determining hydraulic conductivity from grain size curves according to the formula

$$
K=C d_{10}^{2}
$$

in which $C$ is a coefficient (100 in this test) based on grain size and sorting, and $d_{10}$ is the effective grain size for which $10 \%$ of the sample is finer. Both the Hvorslev and Hazen method have been used to approximate hydraulic conductivity for decades and the methodology and empirical equations have been repeatedly refined through peerreviewed results (Landon et al., 2005).

Darcy's law was used to calculate groundwater velocity starting with the relation

$$
q=K\left(\frac{d h}{d l}\right)
$$

where $\mathrm{q}$ is Darcian velocity or specific discharge, $d h$ is head difference and $d l$ is total length. For vertical flow in a unit area, where $d h / d l$ is equal to 1 , groundwater velocity was estimated using

$$
v=\frac{K}{n_{e}}
$$


in which $v$ is groundwater velocity and $n_{e}$ is effective porosity, estimated as 0.4 for the alluvium and pre-eruption silt layers and 0.32 for the pumice aquifer (Schwarz and Zhang, 2003).

\subsection{Surface Discharge (Q)}

\section{Culvert Gaging}

Discharge in Sellers Creek was measured in the culvert where the creek runs under Forest Service Road 9405 UTM 612001 E, 4799536 N. The wetted area in the culvert was calculated by measuring the diameter of the culvert, depth of water, and width of the surface of the stream in the pipe. The radius of the pipe is half the measured diameter. The height of a right triangle with a hypotenuse (equal to radius) from the center point of the culvert circular area to the edge of the water surface and the base equal to half of the stream width, is equal to the radius minus water depth.

The central angle, $\theta$, of the circle sector is found by the trigonometric relation

$$
\theta=\operatorname{arcos}\left(\frac{h}{r}\right) * 2
$$

and the area of the circle sector is found from the equation

$$
A=\left(\frac{\theta}{360}\right) \pi r^{2}
$$


The wetted area, or the circle segment in question is then calculated by subtracting the areas of the two right triangles:

$$
A_{\text {segment }}=A-\left(2\left(\frac{1}{2} b h\right)\right)
$$

in which $b$ and $h$ are measured lengths, but $b$, the more difficult part to measure, was also calculated according to the Pythagorean relation

$$
b=\sqrt{r^{2}-h^{2}}
$$

to provide a check on the field data.

\subsection{Surveying}

Round Meadow was surveyed 12-13-July-2014 and 16-17-August-2014 using 2

Sokkia Set 4B total stations. Two control points were selected based on the ability to sight to all of the piezometers within the meadow from one or the other point.

Additionally the control points themselves and several of the piezometers were surveyed from both points to improve accuracy in the measurements. The procedure followed the double-centering techniques and back-sighting techniques to minimize error (Cruikshank, in review; Moffit and Bouchard, 1992). The sightings were taken from a tripod-mounted total station at the control point to a tripod-mounted prism centered with a plumb line over each piezometer. After measuring distance, slope angle, and horizontal angle, the total station was rotated $180^{\circ}$ on the horizontal axis and vertical axis and the measurements were taken again. To check for errors, the horizontal angles 
should differ by $180^{\circ}$, and the vertical angles should add up to $360^{\circ}$. The total stations and prisms were then switched on each tripod, and the sighting was repeated from the piezometer back to the control point. Care was taken not to shift the tripod while switching instruments, but the height to the instrument tilt axis and the center of the prism was re-measured for each sighting.

The zenith angle, horizontal angle, and slope distance were later used to calculate the relative elevations and positions of each piezometer and spring. The instrument height was measured from the uncapped top of the piezometers, then the pipe height of the piezometers was later subtracted to calculate ground surface elevation. Change in elevation was found using

$$
d Z=S D \cos (Z A)+(I H-R H)
$$

in which $d Z$ is the difference in elevation with respect to the ground surface beneath the total station, SD is the slope distance, ZA is the zenith angle sighted, and IH and $\mathrm{RH}$ are the instrument and reflector height respectively. Several corrections were made for field conditions. The distance measurement is dependent on the speed of light, which is affected by the density of the air through which it is travelling. This was determined by the temperature, pressure, and (to a lesser extent) the relative humidity in the field using the empirical relation 


$$
n_{g}=1+\left(287.604+\frac{4.8864 \mu m^{2}}{\lambda_{c}^{2}}+\frac{0.0680 \mu m^{4}}{\lambda_{c}^{2}} * 10^{-6}\right)
$$

where $\lambda$ is the wavelength of the signal in micrometers and $n_{g}$ is a dimension-less refractive index of standard air. The change in field conditions from this standard air was then found by the equation

$$
n_{a}=1+\frac{2.2767 * 10^{-3} *\left(n_{g}-1\right) * P}{T}+\frac{1.2704 * 10^{-7} * e}{T}
$$

in which $\mathrm{n}_{\mathrm{a}}$ is the field refractive index, $\mathrm{P}$ is pressure $(\mathrm{Pa}), \mathrm{T}$ is temperature $(\mathrm{K})$, and $e$ is vapor pressure $(\mathrm{Pa})$. The new velocity of light in the air at the time and location of testing becomes

$$
v_{a}=\frac{c}{n_{a}}
$$

where $\mathrm{c}$ is the speed of light in a vacuum. The wavelength of the Sokkia EDM signal is $850 \mathrm{~nm}$, the temperature in the field was $292^{\circ} \mathrm{K}$, pressure was estimated at $90000 \mathrm{~Pa}$, and vapor pressure was calculated to be $1302 \mathrm{KPa}$. This gives a field correction of about $28 \mathrm{~mm} / \mathrm{km}$ of horizontal distance. Curvature of the earth and refraction of light would also need to be taken into account when sighting from a total station to a prism, and 
can result in significant elevation errors. However, since all measurements were taken from total stations in both directions, or back sighted, the average of the two readings will give the actual slope distance and angle (Cruikshank, in review).

\subsection{Isotope Sampling}

Water samples were collected for oxygen and hydrogen isotope ratio analysis from 8 different sources around Round Meadow and from a spring at a nearby fen. These sites and the dates of sampling are shown in Table 1 and the location of each is shown in Figure 3. Each of the springs denoted, pine tree, cabin, outlet, and the spring at a fen near FSLR 460 (the 460 spring) were sampled at the orifice where water flowed from the subsurface. The main canal and Sellers Creek were sampled from open surface 
water, and the SE, SW, and vibracore piezometers were sampled by peristaltic pumping.
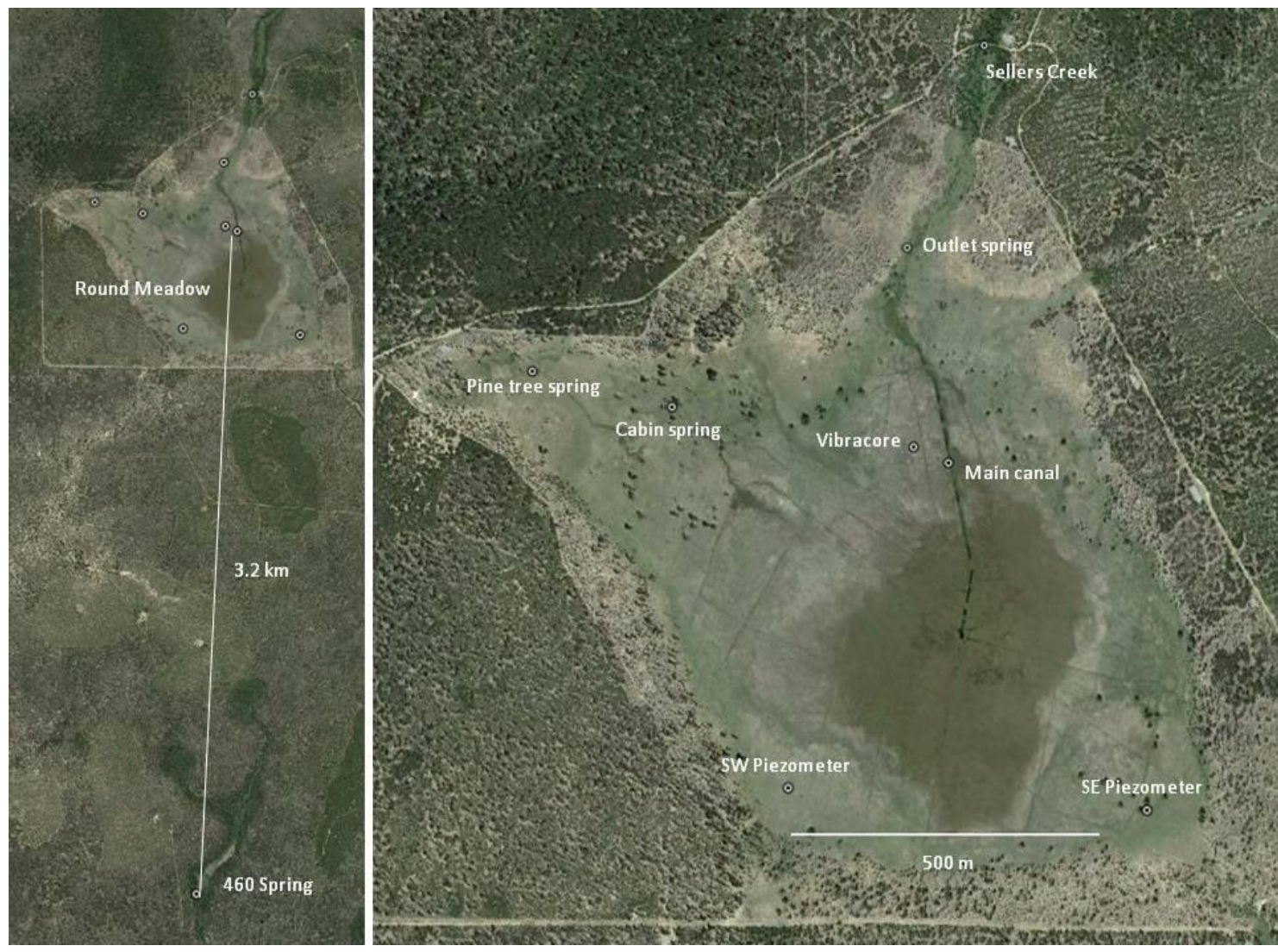

Figure 3: Map of sampling locations for isotope analysis. Locations of Round Meadow and 460 fen at left with detail of 8 Round Meadow sampling sites shown at right.

Table 1 Isotope analysis sampling locations by date

\begin{tabular}{lllll}
\hline Sample Site & \multicolumn{5}{l}{ Sampling Date } \\
\hline \hline Sellers Creek Culvert & 17-May-2014 & 13-July-2014 & 14-September-2014 & 26-October-2014 \\
Outlet Springs & 17-May-2014 & 13-July-2014 & 14-September-2014 & 26-October-2014 \\
Cabin Spring & 17-May-2014 & 13-July-2014 & 14-September-2014 & 26-October-2014 \\
$\begin{array}{l}\text { Pine tree spring } \\
\text { Vibracore }\end{array}$ & 17-May-2014 & 13-July-2014 & 14-September-2014 & 26-October-2014 \\
SE Piezometer & & & 14-September-2014 & 26-October-2014 \\
SW Piezometer & & 13-July-2014 & & \\
460 Fen Spring & 17-May-2014 & 13-July-2014 & 14-September-2014 & \\
Main Canal & & & & 26-October-2014 \\
\hline
\end{tabular}


All samples were collected in $125 \mathrm{~mL}$ LPDE plastic bottles filled completely so that no air bubble was visible when the bottle was inverted. Samples at springs and surface water sources were filled by submerging the bottle and capping underwater where possible. Samples at piezometers were first pumped dry, then allowed to recharge and the bottles were filled using a peristaltic pump and silicon tubing. In all cases the bottles were labeled and the plastic screw-top lids were taped shut immediately after sampling.

Isotope testing was conducted by the Colorado Plateau Stable Isotope Laboratory at Northern Arizona University. The standard for isotopic ratios in water have been established by the International Union of Pure and Applied Chemistry (IUPAC) as the Vienna Standard Mean Ocean Water, which is defined as $\delta^{18} \mathrm{O}, \delta^{2} \mathrm{H}=0 \%$ (IUPAC, 1994; NIST, 2011). VSMOW is normalized by comparison to Standard Light Antarctic Precipitation $\left(\delta^{18} \mathrm{O}=-55.5 \%\right.$, $\delta^{2} \mathrm{H}=-427.5 \%$ ) and the isotopic ratios are computed by the relation

$$
\delta^{18} O \%=\frac{\frac{\left({ }^{18} O\right)}{\left({ }^{16} O\right)} \text { sample }}{\frac{\left({ }^{18} O\right)}{\left({ }^{16} O\right)} \text { standard }} * 1000
$$

for oxygen, and

$$
\delta^{2} H \%=\frac{\frac{\left({ }^{2} H\right)}{\left({ }^{1} H\right)} \text { sample }}{\frac{\left({ }^{2} H\right)}{\left({ }^{1} H\right)} \text { standard }} * 1000
$$


for hydrogen, where the standard is VSMOW/SLAP, a ratio of the defined standard water to a pure sample. The ratios found at the lab were compared to the global meteoric water line established by Craig (1961) as

$$
\delta D=8 * \delta^{18} O+10
$$

\subsection{Water Age Sampling}

Water samples for chlorofluorocarbon age-dating were obtained from the vibracore piezometer and the outlet spring on 26-October-2014. Since CFC and $\mathrm{SF}_{6}$ concentrations are reset by exposure to modern air, groundwater must be sampled to prevent exposure to the atmosphere. The following sampling procedure was based on the USGS protocol (http://water.usgs.gov/lab/chlorofluorocarbons/sampling/bottles/, accessed August 2014) for CFC testing and on advice from the University of Miami Tritium Laboratory, which analyzed the samples. This is the same lab that analyzed the samples obtained by The Nature Conservancy during their study to provide recommendations for environmental levels and flows for the Antelope Grazing Allotment (Aldous and Gurrieri, 2011).

A $500 \mathrm{~mL}$ clean glass bottle was placed in a larger plastic container with at least $10 \mathrm{~cm}$ of head space between the top of the smaller bottle and the larger container. Viton non-reactive tubing was placed at the bottom of the glass bottle and a peristaltic pump was used to fill the bottle. The $500 \mathrm{~mL}$ bottle was overfilled and allowed to spill 
into the larger plastic container until the water covered the top of the sample bottle to a sufficient depth that the bottle could be capped underwater without introducing modern air to the sample. The caps were foil-lined and visually inspected for damage to the foil prior to use, then submerged, filled, and tightened onto the sample bottle underwater. If the sample bottles had no visible head space, they were then removed from the water, dried, labeled and the lids were sealed with electrical tape.

\subsection{Analysis of Variance}

The arithmetic mean is used to predict the most likely value for any random sample in a population and was calculated using the formula

$$
\operatorname{meanX}=\frac{1}{n} \sum_{i=1}^{n} x_{i}
$$

in which $n$ is the number of samples in the population and $x_{i}$ is the value of each ensuing sample. Variance is a measure of how widely the measured values in a population differ with respect to the expected mean. Variance for each of the magnitudes was calculated using the formula

$$
\text { variance } s^{2}=\frac{1}{n-1} \sum_{i=1}^{n}\left(x_{i}-\bar{x}\right)^{2}
$$

using the same notation as in equation 1 and in which $\bar{x}$ is the arithmetic mean. The coefficient of variance is a unit-less measure used to compare the variance in data sets with different absolute values calculated by 


$$
\frac{s}{\bar{x}} * 100
$$

where $s$ is standard deviation and $\bar{x}$ is the sample mean.

The variance of two populations can be compared using the F-statistic, given by the formula

$$
\text { F statistic }=\frac{s_{1}^{2}}{s_{2}^{2}}
$$

in which $s$ is the variance for each population and $s_{1}$ is always greater than $s_{2}$.

The t-statistic compares the means and variances of two populations to quantify how different they are from each other and is given by the formula

$$
t=\frac{\overline{x_{1}}-\overline{x_{2}}}{s_{e}}
$$

in which $\bar{x}$ are still the arithmetic means and $s_{e}$ is the result of a secondary calculation, this is dependent on yet another formula, $s_{p}$.

$$
\begin{gathered}
s_{p}^{2}=\frac{\left(n_{1}-1\right) s_{1}^{2}+\left(n_{2}-1\right) s_{2}^{2}}{n_{1}+n_{2}-2} \\
s_{e}=s_{p} \sqrt{\frac{1}{n_{1}}+\frac{1}{n_{2}}}
\end{gathered}
$$


The comparative t-statistic generated can be checked against known t-tables with degrees of freedom equal to (number of samples-1) to determine the probability that the two populations are different. For the isotopic comparisons in this study, the acceptable margin of error $(\alpha)$ was $0.05 \%$, or 1.96 standard deviations.

The data from the 2 pressure transducers was compared to test for heterogeneities in the pumice aquifer. The data from the transducers was not compared directly since the absolute pressure was different at each piezometer. Instead the percent change of the water level was calculated for each piezometer. This was done by finding the absolute difference in each 30 minute reading from the previous one for each of the sensors. The percent difference was calculated by

$$
\Delta \%=\frac{\left|\Delta P_{1}-\Delta P_{2}\right|}{\left(P_{1}+P_{2}\right) / 2} \times 100
$$

where the numerator is the absolute value of the difference between the change in each sensor, and the denominator is the average of the 2 measurements at each 30 minute increment.

\subsection{Estimation of Error}

The measured parameters in the water budget are dependent on the level of precision of the measuring instrument. The water levels in the piezometers were measured using an ordinary metric tape, but observations were precise to no less than 1 $\mathrm{cm}$. Subsurface measurements were made with using the same tape but were 
dependent on marking the depth of the auger hole, so the precision was estimated only to within $5 \mathrm{~cm}$. The precision of other measurements was dependent on the instruments used and these were obtained from the manufacturer or data provider (Table 2).

Table 2: Instrument and model uncertainty for meteorological and stream gaging data

\begin{tabular}{|c|c|c|c|c|c|c|c|}
\hline $\begin{array}{l}\text { Snotel } \\
\text { Station }\end{array}$ & $\begin{array}{l}\text { Prism } \\
\text { model }\end{array}$ & Temp & $\begin{array}{l}\text { Relative } \\
\text { Humidity }\end{array}$ & $\begin{array}{c}\text { Solar } \\
\text { Radiation } \\
\end{array}$ & $\begin{array}{c}\text { Wind } \\
\text { Velocity }\end{array}$ & $\begin{array}{c}\text { Stream } \\
\text { Gage }\end{array}$ & $\begin{array}{c}\text { Stream Area } \\
\text { Estimates }\end{array}$ \\
\hline $1 \%$ & $10 \%$ & $\pm 0.6^{\circ} \mathrm{C}$ & $3 \%$ & $5 \%$ & $5 \%$ & $1 \%$ & $5 \%$ \\
\hline
\end{tabular}

Error for the Penman method for estimating evapotranspiration was calculated using propagation of measured error for each of the terms using the equation for additive or subtracted operations

$$
\text { where } x=a+b-c \text {, then } u x=\sqrt{u a^{2}+u b^{2}+u c^{2}}
$$

in which $x$ is the calculated parameter, $a, b, c$ are the measurements for the calculation and $u$ is the uncertainty is the measurements. For multiplication or division the equation becomes

$$
\text { where } x=a * \frac{b}{c} \text {, then } \frac{u x}{x}=\sqrt{\left(\frac{u a}{a}\right)^{2}+\left(\frac{u b}{b}\right)^{2}+\left(\frac{u c}{c}\right)^{2}}
$$

with the same variables as above. A sample calculation for the Penman operation was 


$$
\frac{u E T}{|E T|}=\sqrt{\frac{\left.\frac{.08}{|\Delta|}\right)^{2}+\left(.05^{2}+.04^{2}\right)+\left(\frac{.1}{|\gamma|}\right)^{2}+\left(\frac{.01}{\left|K_{E}\right|}\right)^{2}+\left(\frac{.05}{|\lambda|}\right)^{2}+\left(\frac{.05}{|v|}\right)^{2}+\left(\frac{.07}{\left|e^{*}\right|}\right)^{2}+\left(\frac{.03}{\left|W_{a}\right|}\right)^{2}}{\left(\frac{.05}{|\lambda|}\right)^{2}+\left(.08^{2}+.1^{2}\right)}}
$$

with the same variables as for the Penman equation. The calculated error for the propagated uncertainty in measurement was $32 \%$.

\section{Chapter 3: Data and Results}

The hydrogeologic analysis of Round Meadow occurred in water year 2014 (WY2014) and 9 months of water year 2015. Both years were anomalous relative to the historical record of the past 30 years. WY2014 was a drought year, with total precipitation of only $46.7 \mathrm{~cm}$, the third driest in the past 30 years. The cumulative precipitation curve is included in Figure 4 for the Chemult Alternate SNOTEL site. WY2015 was anomalous in that precipitation fell mostly as rain. Although cumulative precipitation was above the 30 year average for most of the water year, snow pack did not accumulate in the study area. The drought of WY2014 allowed data to be gathered on the system under stressed conditions. Likewise, a rainfall-dominated winter precipitation regime of WY2015 allowed data to be gathered under conditions that were distinctly different than observed during the past 30 years. These data sets are supplemented by field observations made during WY2010 through WY2013 as part of ongoing hydrologic investigations in the Walker Rim study area. Where these data 
provide insight into hydrologic processes active in Round Meadow they are included in this analysis.

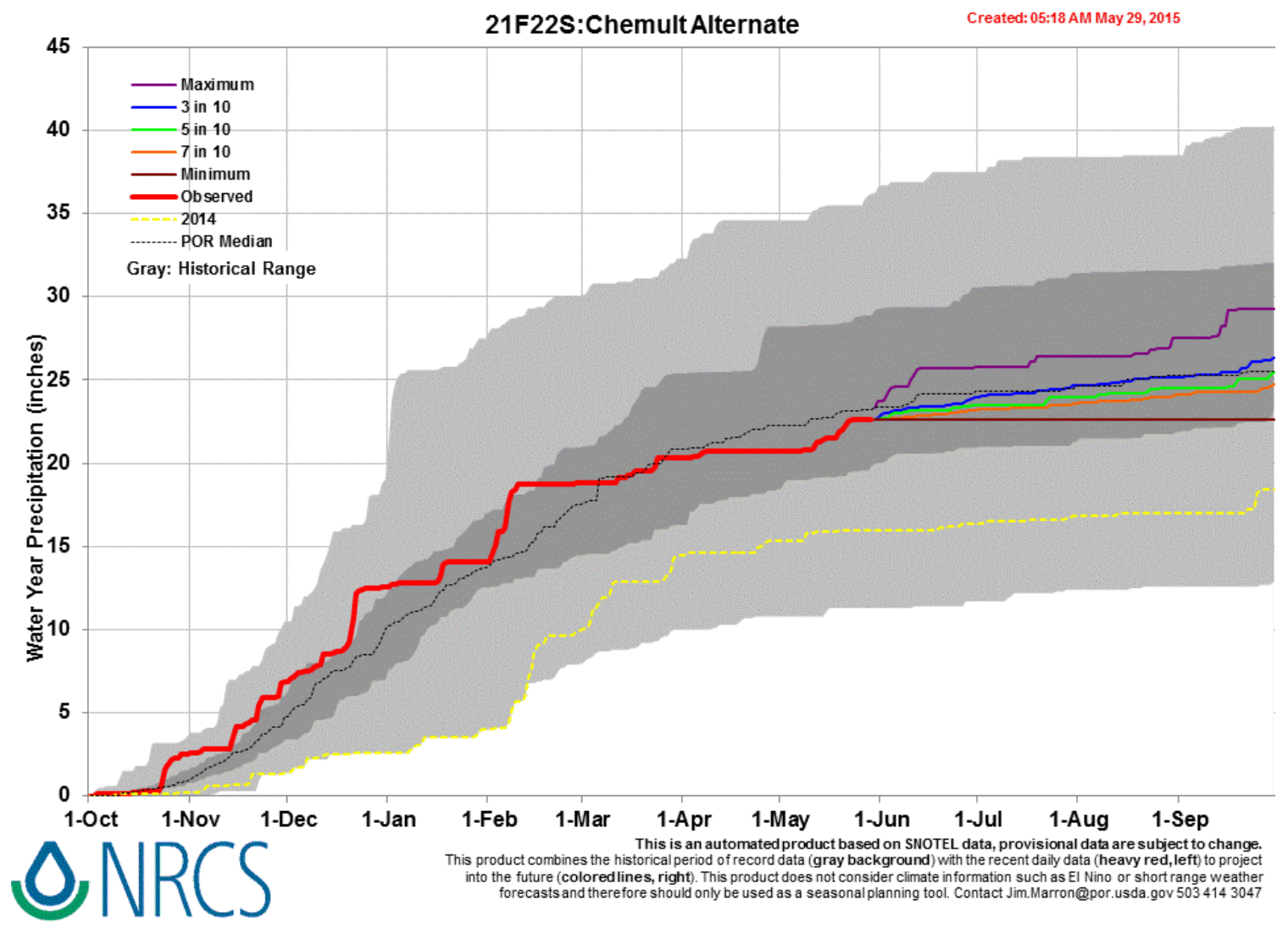

Figure 4: Precipitation for current water year, prior water year (WY2014), historical range, and expected values from the period of record. Note that until mid-February WY 2014 set the historical minimum for precipitation (since 1981), and that WY 2015 had more precipitation by 1-March-2015 than all of WY 2014.

The Round Meadow hydrologic system consists of 4 components: the meadow, the fen, the springs, and the outflow area which becomes Sellers Creek. Each of these components and their influence on the other components will be defined below. After this presentation, the results of the water budget will be given, with the supporting data 
that were used to calculate each of the inputs and outputs. Finally, the water age testing data that contributed to the interpretation of the hydrologic system will be presented.

\subsection{The Central Meadow}

The central part of Round Meadow is a flat, seasonally ponded surface about 600 $\mathrm{m}$ by $700 \mathrm{~m}$ marked by the blue line in Figure 5 at or below $1710 \mathrm{~m}$ elevation. The central, seasonally ponded meadow is well delineated by $1710 \mathrm{~m}$ elevation except in the outflow area and where fans enter the meadow on the southwest and eastern sides. It slopes very subtly (0.0025) to the east and when water levels are high enough it drains over the bedrock knickpoint in the northeast corner. Also visible on Figure 5 is a network of canals which were excavated by ranchers during the 1970s to accelerate drainage in the meadow. The largest of these is a central canal approximately $3 \mathrm{~m}$ wide that runs from the center of the meadow almost due north to the knickpoint. The U.S. Forest Service attempted to reduce the effect of the canal network in 1992 by filling in parts of the canals (visible in Figure 5 as regularly spaced flat sections) and piling a rock and earth dam on the central canal near the location of the knickpoint. 


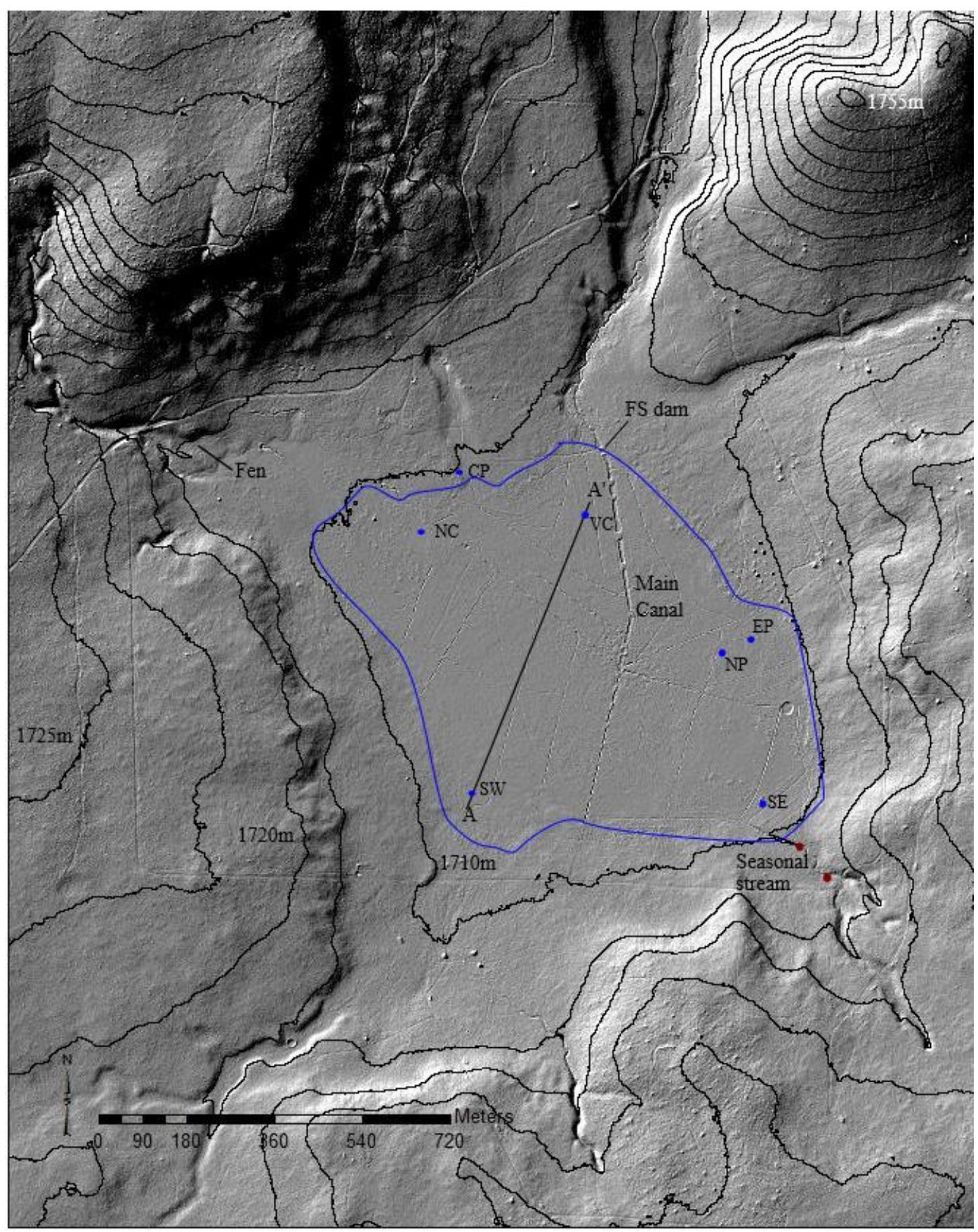

Figure 5: Area map of Round Meadow, showing locations of the fen, main canal, and Forest Service dam, sited near the lowest point in the meadow. The blue line that roughly follows the $1710 \mathrm{~m}$ contour shows the area of the central, seasonally ponded part of Round Meadow. Also marks locations of 7 piezometers - CP: cabin, NC: north channel, VC: vibracore, EP: eastern, NP: nested, SE: southeast and SW: southwest. The cross section in Figure 8 was drawn on the line from $A$ to $A^{\prime}$. The two red dots at the SE corner mark the locations where a seasonal stream was gaged on 7-March-2015 and where it soaked into the pumice. 
Although flow has not been observed, the canals store water after the surrounding meadow is dry. Many of the smaller canals connect to drain into the main canal, water in others becomes stagnant and evaporates in place. All of these peripheral canals went dry in WY 2014, only the main canal and the outflow channels from the springs held water. The north end of the main canal is the topographic low point in the meadow. The area immediately north of the Forest Service dam is also perennially inundated and wider than the canal (approximately $10 \mathrm{~m}$ ), and at least a portion of this water is inferred to be flowing through or under the dam.

The sediments found in the central meadow were divided into different units based on stratigraphic position and origin. The thickness, sorting and composition of each layer is discussed in more detail below. The lowest are the silt-sized sediments that formed the pre-eruption surface. These are in sharp contact with the Plinian pumice fall, which is overlain by a thin well-sorted sand layer below a thicker layer of reworked pumice. These three layers host the pumice aquifer, and are under- and overlain by relatively less permeable diatomaceous silts, as shown in Figure 6. Core logs and UTM locations for 4 borings used to develop the cross section can be found in Appendix E. 


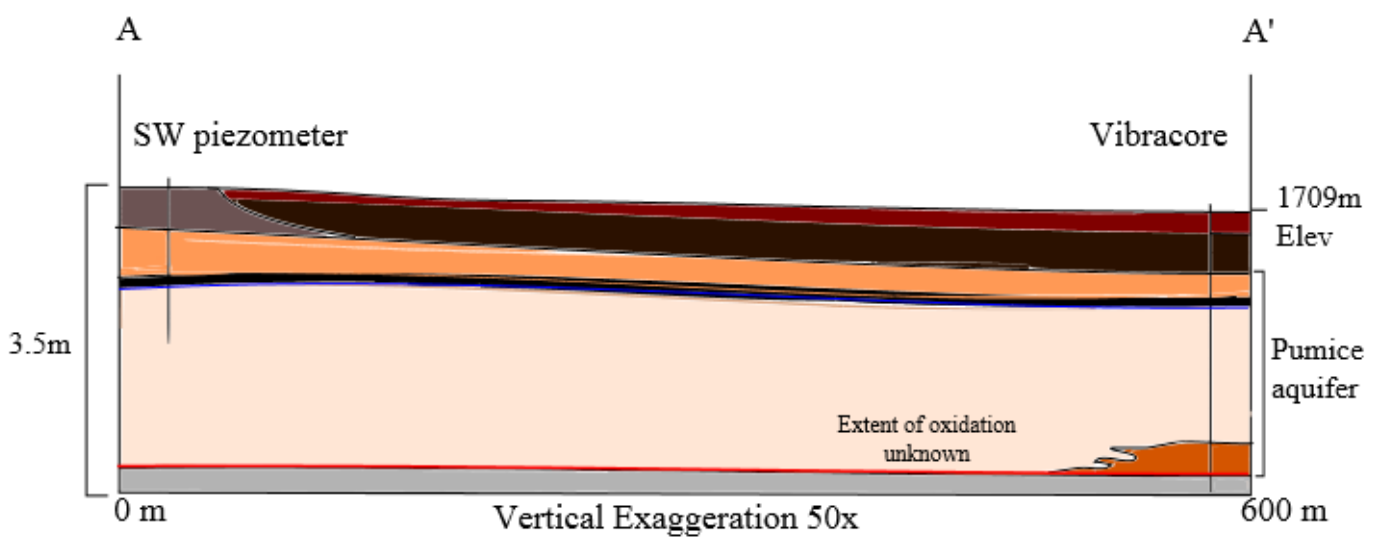

Holocene

Erosional upper contact of
Plinian fall pumice

Figure 6: Cross section of central Round Meadow. The sediments at the surface near SW piezometer are a fan from a channel to the southwest, while the organic silt layers thicken near the middle of the meadow. The thin lithic- and crystal-rich lag sand marks the contact with the Plinian fall pumice throughout the area. The contact at the kill horizon in the vibracore hole at the lower right of this Figure is shown in the photograph, Figure 7.

The deepest cores taken in Round Meadow penetrated $60 \mathrm{~cm}$ of fine grained, indistinctly bedded $(1-4 \mathrm{~cm})$ diatomaceous sediment that underlies the Plinian pumice fall. Color variation suggesting crude bedding is shown in Figure 7 below the kill horizon at $331 \mathrm{~cm}$ depth. 


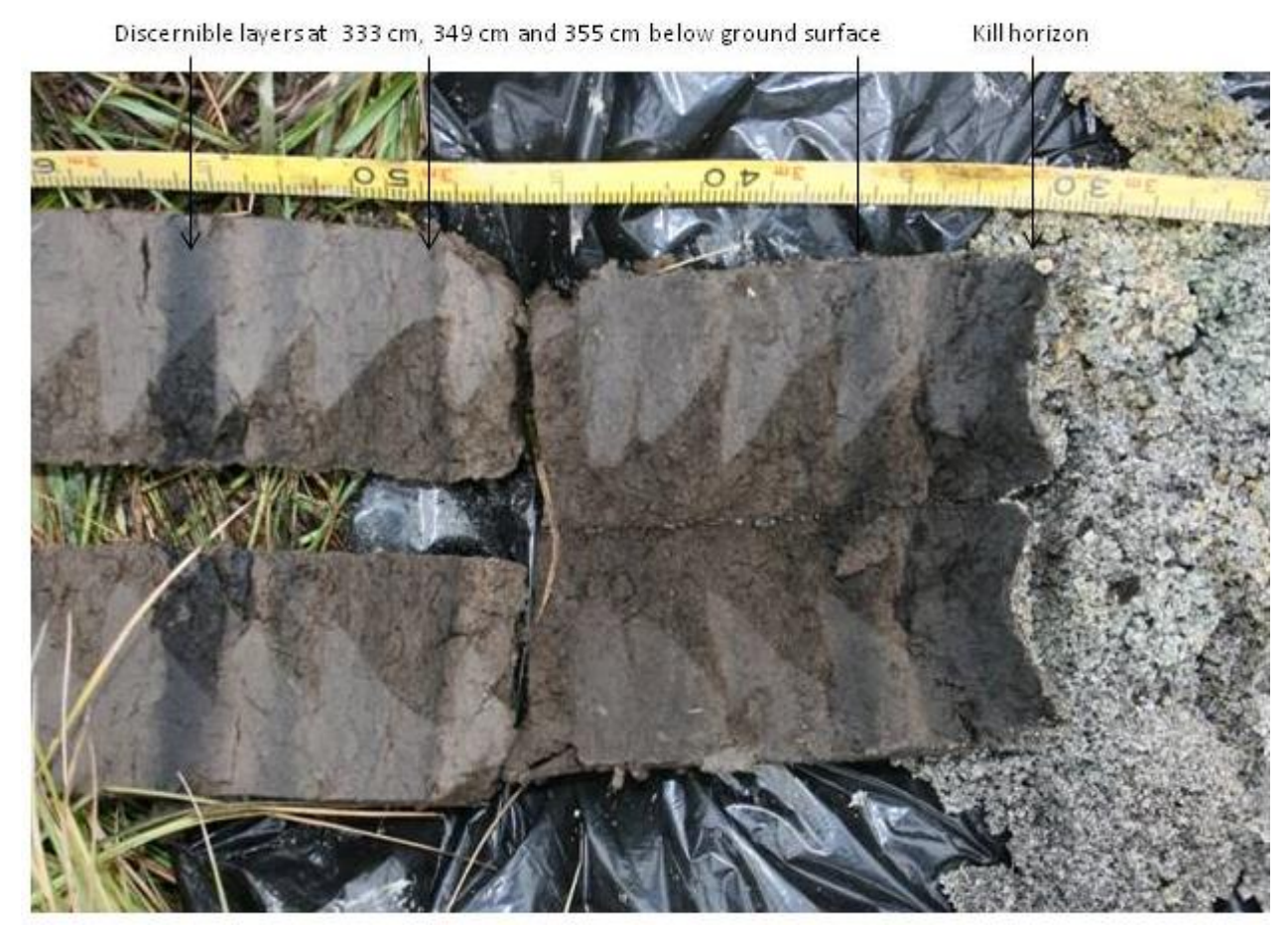

Figure 7: Photograph of the vibracore sample from Round Meadow. The kill horizon at $331 \mathrm{~cm}$ below local ground surface shows the Plinian fall pumice in sharp contact with the organic-rich pre-eruption surface.

Three samples collected at $52 \mathrm{~cm}, 23 \mathrm{~cm}$, and $5 \mathrm{~cm}$ below the contact with the pumice deposit were analyzed by scanning electron microscope (SEM) and photomicrographs presented in Figure 8 demonstrate the characteristics of this poorly lithified diatomaceous siltstone. The stratigraphic position of the diatomaceous siltstone is interpreted to overlie the welded tuff which gently dips to the south beneath the meadow. The orientation of the welded tuff is based on outcrop and float distribution along Sellers Creek and the western edge of the meadow. Float of the welded tuff is present in the bed of a stream valley entering the southwestern part of the meadow. 
Based on these observations, the welded tuff dips 1 to 2 degrees to the south and is present beneath the meadow.

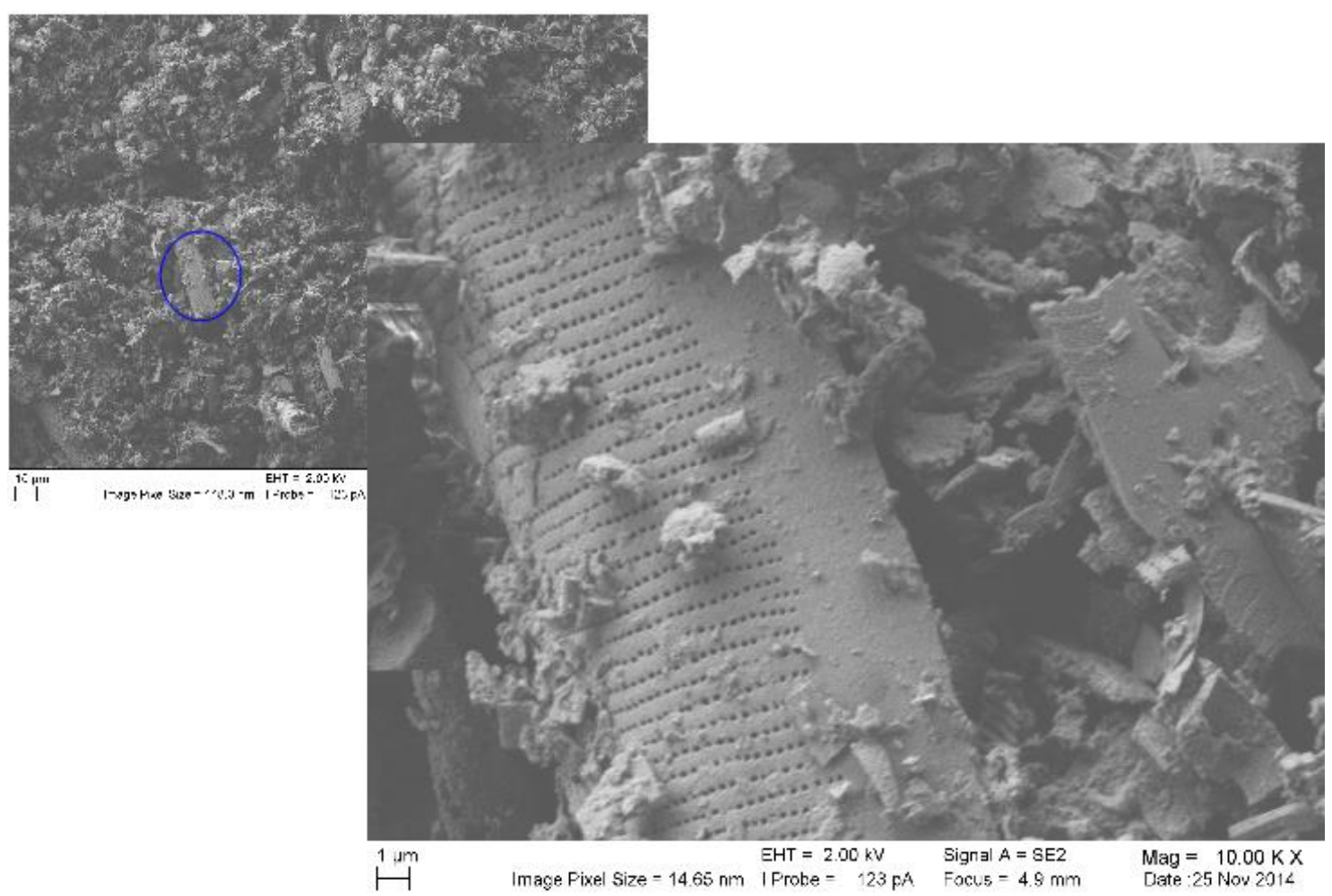

Figure 8: Diatomaceous silt $23 \mathrm{~cm}$ below kill horizon. Magnification on the smaller image was $990 \mathrm{x}$, on the larger image was $10,000 \mathrm{x}$.

North of Round Meadow these sedimentary rocks are interpreted to be overlain by basalt lava flows that cap a butte that lies northwest of the meadow. In that area, these sedimentary rocks are interpreted to contribute to small scale landslide features noted on LiDAR images. Tentative correlation based on geochemistry of the welded tuff 
with trachy dacite to rhyolite domes at Wocus and Little Wocus buttes $56 \mathrm{~km}$ to the south suggest a Pliocene age for these deposits.

The kill horizon was in sharp contact with the primary Plinian pumice fall at an organic-rich paleosol developed from the diatomaceous siltstone. The base of the Plinian pumice fall consists of $15 \mathrm{~cm}$ of phenocryst crystals, lithic fragments, and sparse pumice. This basal layer was overlain by 1-1.5 m of crystal- and lithic-bearing pumice lapilli (0.3-0.7 cm diameter) that graded upward to include pumice to $1.5 \mathrm{~cm}$ in diameter and poorer sorting. In areas above approximately $1710 \mathrm{~m}$, the upper pumice unit is partially preserved and is locally overlain by organic-rich to organic-poor alluvium. In the fen area in the northwestern part of the meadow peat is present above the partially eroded upper pumice unit. In a tree root ball northwest of the fen area, the upper pumice is poorly sorted with pumice lapilli to blocks from $1 \mathrm{~cm}$ to $7 \mathrm{~cm}$ in diameter.

Where elevation is below about $1710 \mathrm{~m}$ in the meadow, the upper unit of the primary Plinian pumice fall is eroded. The pumice is overlain by a phenocryst and lithicrich sand between 5 and $12 \mathrm{~cm}$ thick that grades upward into subangular pumice pebbles. This, in turn, is overlain gradationally by bedded silt and vitric diatomaceous silt (Figure 6) with thin $(5-10 \mathrm{~cm})$ organic-rich and charcoal-bearing layers near the ground surface. Grain size analysis of this layer indicates a fine grained silt with fewer than $10 \%$ clay sized grains. During collection of cores, there was approximately $25 \%$ compaction, particularly in layers above the Plinian pumice fall. Three samples taken from different levels in the silt below the modern ground surface are all diatomaceous (sample 
collected at $40 \mathrm{~cm}$ below local ground surface shown below in Figure 9), indicating that the basin hosted a persistent lake or seasonal wetland after the eruption.

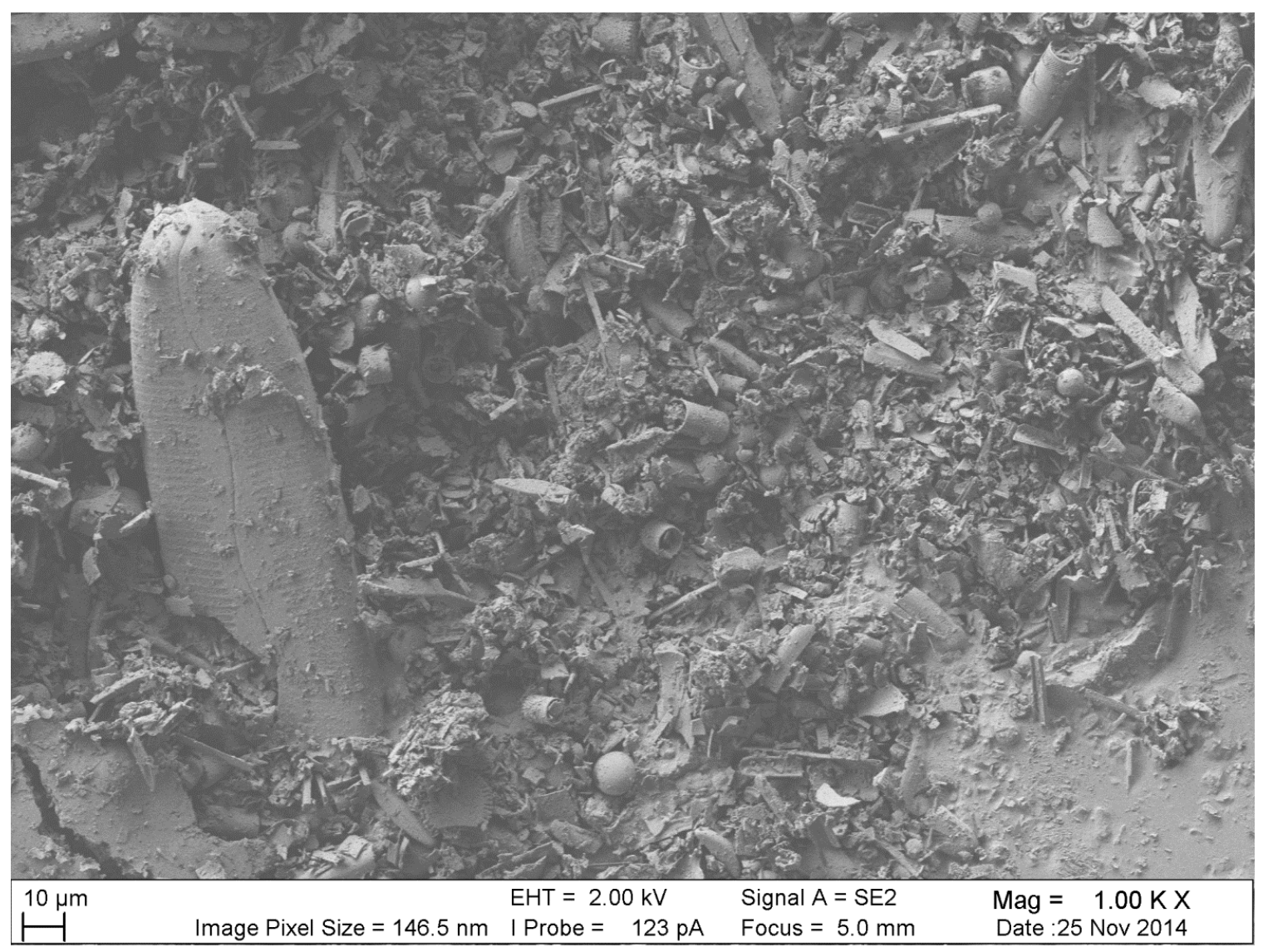

Figure 9: Diatomaceous silt $40 \mathrm{~cm}$ below modern ground surface in Round Meadow. From visual inspection the frustules were better preserved in the post-eruption samples. Magnification is $1,000 \mathrm{x}$, about the same as the base image in Figure 7.

The piezometers in the meadow show the patterns of recharge and depletion of the pumice aquifer through the water year (Figure 10). The aquifer is hosted in the Plinian fall pumice, the overlying lag sand and in the reworked pumice and sand layers. Through 4 years of monitoring the southeast margin of the meadow had water closer to the local ground surface early in the year, but the northern side of the meadow 
remained saturated through the summer. The hydrograph also demonstrates how summer storage in the meadow diminished with declining precipitation in WY 2013 and 2014. Although each of the piezometers started each season with similar water levels, the fall readings show a consistent decline that follows the decline in annual precipitation. 

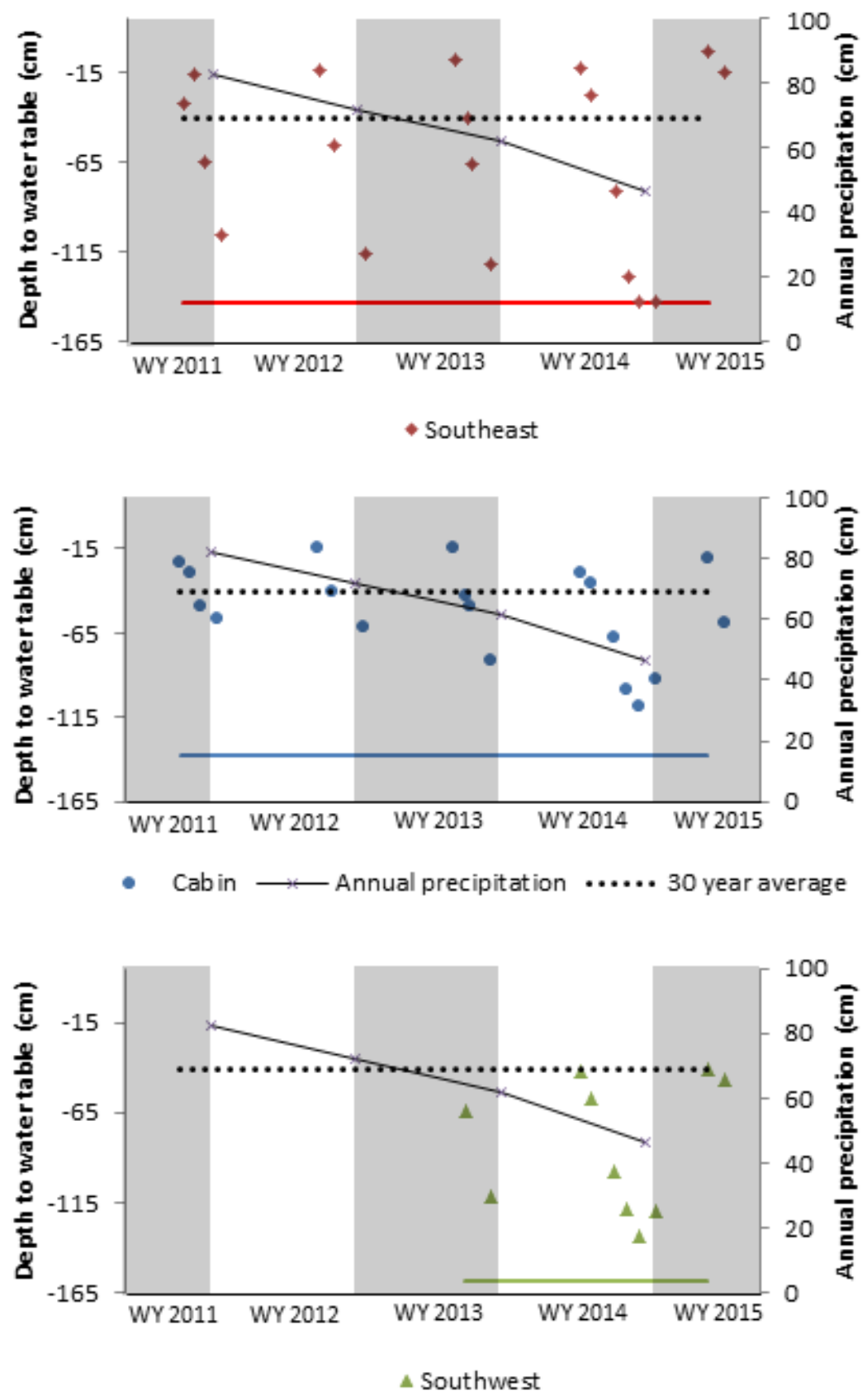

Figure 10: Hydrographs from WY 2011 to WY 2015 for the 3 piezometers in Round Meadow with at least a year of water level data. The steady decline in the lowest reading of the year over the 4 year span illustrates the effect of diminishing storage in the meadow. The dotted line is the $\mathbf{3 0}$ year average precipitation, the solid black line is the annual precipitation for WY2011 to WY2014 for the Chemult Alternate SnoTel site, and the colored lines at the bottom of graph are the maximum depth of piezometers below the local ground surface. The cabin piezometer is at $1710 \mathrm{~m}$ elevation and the SE and SW are at $1709 \mathrm{~m}$. 
Several piezometers were installed in WY 2014 to monitor water levels in the pumice aquifer relative to the surface water in the canals. Stratigraphic data are not available from the canals, but where dry they are observed to commonly be cut about $20-30 \mathrm{~cm}$ below local ground surface. It is inferred that the base of the canals does not cut into the Plinian pumice fall deposit, which is about $1 \mathrm{~m}$ below ground surface in the meadow. The exception may be the central canal, the largest and deepest canal.

A pair of nested piezometers was placed near a canal (NP in Figure 5) with one screened in the Plinian pumice fall and one screened in the overlying deposits. In June the water level in the piezometer screened in the pumice was $19 \mathrm{~cm}$ below local ground surface while the water in the shallow piezometer was $35 \mathrm{~cm}$ deep. Another single piezometer was emplaced (NC in Figure 5) about $7 \mathrm{~m}$ from a canal at the northern edge of the meadow that was observed to carry discharge from the cabin spring throughout the year. The eastern and vibracore piezometers were also installed (EP and VC in Figure 5) to form a rough square enclosing the main canal along with the existing SE and SW piezometers. The site of the vibracore piezometer was used as a sighting point when the meadow was surveyed and the elevations of each of the piezometers relative to the vibracore are given in Table 3. 
Table 3: Surveyed elevations and depth to water table for 6 piezometers emplaced near canals in Round Meadow. The site of the vibracore was used as the zero elevation datum to survey to all the other piezometers.

\begin{tabular}{ccccccc}
\hline Piezometer & Vibracore & Eastern & Southwest & Southeast & Nested (NP) & $\begin{array}{c}\text { North } \\
\text { Canal (NC) }\end{array}$ \\
\hline \hline$\Delta$ Elevation (cm) & - & 49 & 41 & 71 & 38 & 90 \\
Distance (m) & - & 415 & 589 & 688 & 404 & 330 \\
Error (cm) & & 7.5 & 6 & 2.5 & 4 & 0.6 \\
$\begin{array}{c}\text { Depth to Water } \\
\text { (cm) }\end{array}$ & & & & & & \\
$\quad$ July & -47 & -50 & -98 & -81 & -31 & -51 \\
$\quad$ August & -79 & -92 & -118 & -128 & dry $(66 \mathrm{~cm})$ & -78 \\
September & -94 & - & -133 & dry $(141 \mathrm{~cm})$ & - & -87 \\
October & -54 & -96 & -120 & dry & -62 & -51 \\
\hline
\end{tabular}

Water was present at the ground surface in both the main canal and the north canal flowing from the cabin spring throughout the summer and fall of WY2014 and early WY2015. On 7-March-2015 a seasonal stream was found flowing in the channel that enters the basin from the southeast. Visual observations and elevation indicate that the channel is cut in the upper Plinian pumice fall. This was gaged at $0.005 \mathrm{~m}^{3} / \mathrm{s}$ at UTM $612396 \mathrm{E}, 4798070 \mathrm{~N}$ but the stream diminished and fully soaked into the ground at an area where the channel flattened into the central meadow (UTM $612302 \mathrm{E}, 4798134 \mathrm{~N}$ ).

\subsubsection{Hydraulic Conductivity}

Three layers in Round Meadow, the pre-eruption diatomaceous silt, lower pumice unit of the Plinian pumice fall, and the post-eruption diatomaceous silt, were tested to determine hydraulic conductivity. The methods of estimating hydraulic conductivity included two field slug tests, grain size analysis coupled with the Hazen method, and a laboratory constant-head permeameter test. Each method is described in 
the methods section. Groundwater velocity depends on head differential, but with limited head space above the pre-eruption surface, controlling factors for flow are hydraulic conductivity and porosity and these were used to calculate vertical flow potential in Table 4.The groundwater flow for all 3 units was calculated using the hydraulic conductivity given by the Hazen method. The results of all 3 methods are shown in Table 4.

Table 4: Hydraulic conductivity and calculated groundwater velocity for $\mathbf{3}$ main depositional units in Round Meadow.

\begin{tabular}{cccccc}
\hline Sediment Type & $\begin{array}{c}\text { Slug Test 1 } \\
(\mathrm{cm} / \mathrm{s})\end{array}$ & $\begin{array}{c}\text { Slug Test 2 } \\
(\mathrm{cm} / \mathrm{s})\end{array}$ & $\begin{array}{c}\text { Permeameter } \\
(\mathrm{cm} / \mathrm{s})\end{array}$ & $\begin{array}{c}\text { Hazen Method } \\
(\mathrm{cm} / \mathrm{s})\end{array}$ & $\begin{array}{c}\text { Groundwater } \\
\text { FlowVertical } \\
(\mathrm{cm} / \mathrm{s})\end{array}$ \\
\hline $\begin{array}{c}\text { Primary } \\
\text { pumice }\end{array}$ & 0.00063 & 0.00019 & 0.013 & 0.0625 & 0.021 \\
$\begin{array}{c}\text { Diatomaceous } \\
\text { silt overlying } \\
\text { pumice } \\
\text { aquifer } \\
\text { (hydrometer) }\end{array}$ & & & & \\
$\begin{array}{c}\text { Pre-eruption } \\
\text { sediments } \\
\text { underlying } \\
\text { pumice } \\
\text { aquifer } \\
\text { (hydrometer) }\end{array}$ & & & \\
\hline
\end{tabular}

The slug test was conducted at one of three vibracore sites for a screened interval in the lower pumice unit of the Plinian pumice fall. The hydraulic conductivity measured by this test represents in situ drawdown rates and are viewed as the most 
reliable for this unit. The Hazen method based on grain size analysis and the permeameter test were conducted in the laboratory on disturbed samples that lack the internal structure of the pumice unit. The Hazen method was the only measure available for all 3 sediment types and was used when comparing hydraulic conductivity between the layers. The laboratory methods may overestimate hydraulic conductivity due to discrepancies in field and laboratory conditions or assumptions in the empirical model (Bouwer and Rice, 1976; Fetter, 2001; Dingman, 2002). In particular, the packing and structural arrangement that is present in the subsurface is lost during laboratory testing.

The relatively high hydraulic conductivity measured in the lower pumice unit aquifer is supported by data from the pressure transducers (Figure 11) which recorded water level data every 30 minutes in the vibracore and Eastern piezometers, about 400 $m$ apart. Although the piezometers are emplaced at different depths, resulting in different absolute pressure readings, the response of each transducer to daily and seasonal variability is nearly identical, indicating an isotropic aquifer. The greatest percent difference in change at each transducer for every 30 minute interval from 12 July-2014 to 26 -October-2014 was $0.057 \%$, a high degree of similarity in fluctuations of the water table at the 2 piezometers. The spike in the graph of the vibracore in August was when it was filled to monitor drawdown for the slug test and the small drop in September was due to purging during the collection of a sample for isotope analysis. 


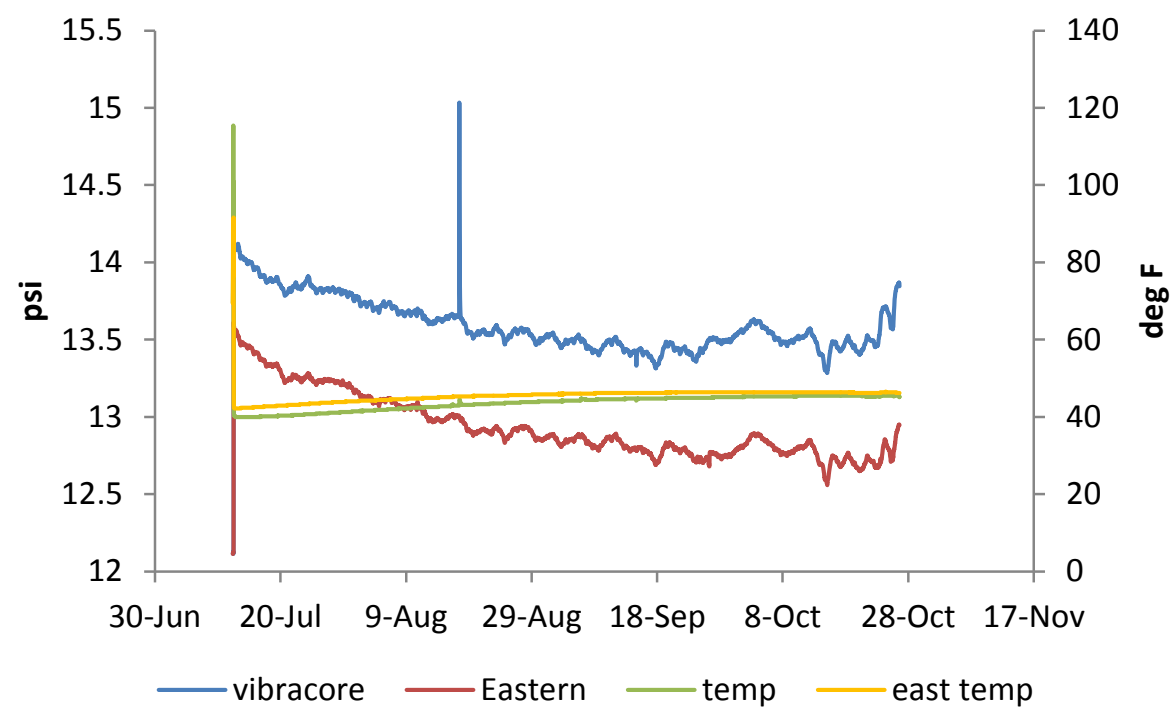

Figure 11: Pressure transducer and temperature data for 2 piezometers screened in the pumice approximately $400 \mathrm{~m}$ apart.

The grain size data presented in Figure 12 that was used in the Hazen method for finding hydraulic conductivity, graphically demonstrates the distinct differences in grain size between the pumice aquifer and both the underlying and overlying diatomaceous sediment. The hydraulic conductivity for the pre-eruption diatomaceous silt (Table 4) suggests that vertical movement of groundwater through the underlying unit is negligible for meaningful time scales. For this reason, the movement of groundwater out ( $\left(\mathrm{GW}_{\text {out }}\right)$ of the meadow is negligible and this term was dropped from the water budget presented below.

As noted above, the nested piezometer that was completed in the pumice had $16 \mathrm{~cm}$ greater head than the nested piezometer that was completed in the overlying diatomaceous silt. This indicates that the overlying silt creates hydraulic pressure in the 
pumice, supporting the conclusion that the pumice is a confined aquifer. Borings and natural pipe features in the fen area that flow with artesian pressure when the pumice layer is penetrated will also be discussed below.

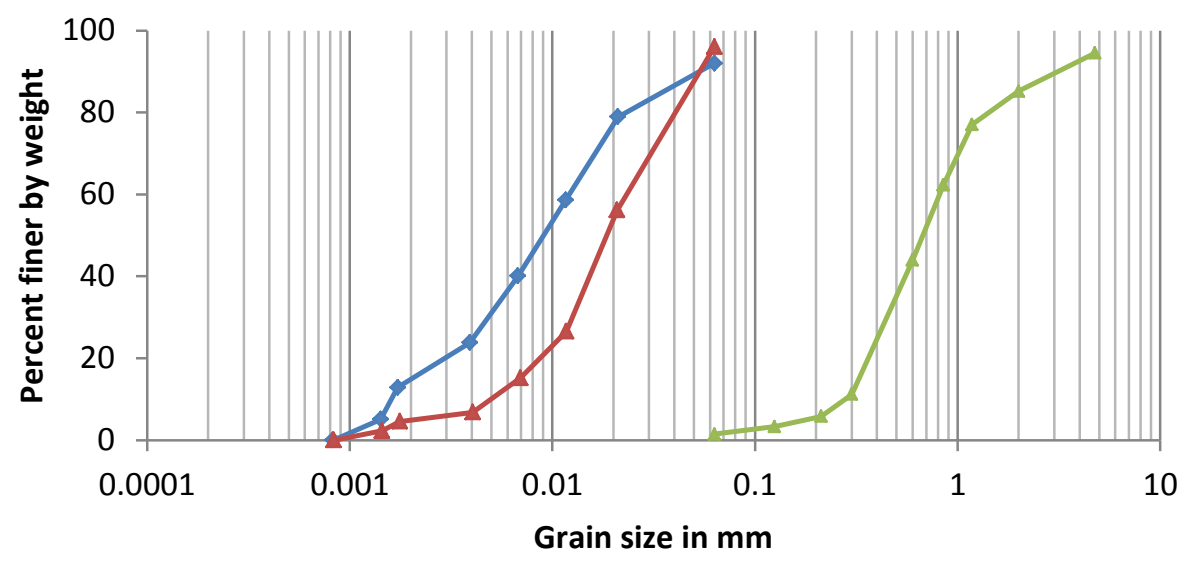

$\leadsto$ Pre-eruption sediment $\multimap$ Post-eruption sediment $\longrightarrow$ Plinian fall pumice

Figure 12: Grain size analysis for the 3 main depositional units in Round Meadow graphically demonstrates approximately 2 orders of magnitude difference in typical diameter between the Plinian fall pumice and the underlying or overlying sediment.

Likewise, the hydraulic conductivity estimated using the Hazen method for the post-eruption diatomaceous silt suggests the pumice aquifer is weakly confined in the parts of the meadow where the upper pumice unit has been eroded and the lower pumice unit is overlain by diatomaceous silt that accumulated in lake and wetland environments. The canal network in the meadow appears to be hosted primarily within these sediments. The hydraulic conductivity of the post-eruption diatomaceous silt suggests the lower pumice unit in the meadow at elevations below approximately 1710 $m$ is a confined aquifer. 


\subsubsection{Stable Isotope Analysis}

Water samples were obtained from the SE, SW, and vibracore piezometers and from the main canal in Round Meadow for analysis of $\mathrm{O}$ and $\mathrm{H}$ isotopic ratios. These were compared to samples from the springs and the outflow creek (the isotopic data for all samples is in Appendix D). Initially, the samples obtained from the piezometers screened in the pumice aquifer appear to be radically different from other waters in the area, as shown in the "piezometers" row in Table 5, but this result was heavily skewed by a single outlier. The sample in question was collected from the vibracore piezometer in September 2014, and the isotopic ratios were intriguing since this was the deepest core obtained in Round Meadow, and the only one known to have penetrated the preeruption surface. The result was sufficiently surprising that the lab was asked to re-test the sample and the results were replicated $(\delta \mathrm{D}=-86.99, \delta \mathrm{O}=-12.11$, and $\delta \mathrm{D}=-86.76, \delta \mathrm{O}=$ -12.29). However, a second sample was collected in October 2014 and the results of the September test could not be replicated $(\delta D=-114.99, \delta O=-15.62)$. Isotopic fluctuations of this magnitude are not common (Faure and Mensing, 2005) and long term studies have shown that isotopic ratios for groundwater have little variability $( \pm .05-.08 \% \circ \delta 0)$ for small basins in the Cascade Range (McGuire et al., 2005; Jefferson et al., 2006). The September vibracore sample was deemed to be a statistical outlier by finding the median of the smallest half of the data ( $1^{\text {st }}$ quartile) and the median of the larger half $\left(3^{\text {rd }}\right.$ quartile) and subtracting the first from the third to obtain the fourth spread $\left(f_{s}\right)$. An outlier is considered extreme if it is more than $3\left(f_{s}\right)$ from the nearest quartile (Devore, 
2012). The deviation for the sample collected in September was $16.7\left(f_{s}\right)$ for $\delta D$ and $14.7\left(f_{s}\right)$ for $\delta 0$.

Table 5: Statistics on isotopic ratio for springs, surface water, piezometers, and for the piezometers with the extreme outlier omitted (piezometers 2).

\begin{tabular}{lcccccc}
\hline & \multicolumn{2}{c}{ Mean } & \multicolumn{2}{c}{ Standard Deviation } & \multicolumn{2}{c}{ Coefficient of Variation } \\
& $\delta \mathrm{D} \%$ o & $\delta^{18} \mathrm{O} \% \mathrm{o}$ & $\delta \mathrm{D} \% \mathrm{o}$ & $\delta^{18} \mathrm{O} \% \mathrm{o}$ & $\delta \mathrm{D} \% \mathrm{o}$ & $\delta^{18} \mathrm{O} \% \mathrm{o}$ \\
Springs & -116.33 & -15.73 & 1.31 & 0.31 & -0.011 & -0.02 \\
Piezometers & -107.32 & -14.65 & 13.60 & 1.70 & -0.13 & -0.12 \\
Piezometer 2 & -114.09 & -15.5 & 1.49 & 0.20 & -0.013 & -0.013 \\
Surface & -106.54 & -13.89 & 13.79 & 2.42 & -0.13 & -0.17 \\
Totals & -112.79 & -15.17 & 8.95 & 1.44 & -0.08 & -0.09 \\
\hline
\end{tabular}

With this outlier removed (Piezometer 2 in Table 5), the isotopic composition of water in the pumice aquifer is more consistent with other low temperature water in the region (Palmer et al., 2006). However, when the piezometer and spring data are plotted on the GMWL, the isotopic ratios of the springs were consistently lighter (Figure 13). The waters from the springs were therefore considered as a separate group, discussed below. The samples from the pumice aquifer were compared to the sample from the nearby canal on 27-October-2014. These again represent 2 distinctly different types of water, but this is consistent with surface water compared to groundwater. Isotopic ratios for atmospheric temperature waters that fall below or to the right of the GMWL are interpreted to have undergone evaporative fractionation as the lighter isotope is preferentially removed in water vapor leaving the liquid water relatively enriched with the heavier isotope (Cappa et al., 2003). Evaporative trends at the meadow are 
examined more thoroughly in the outlet section below

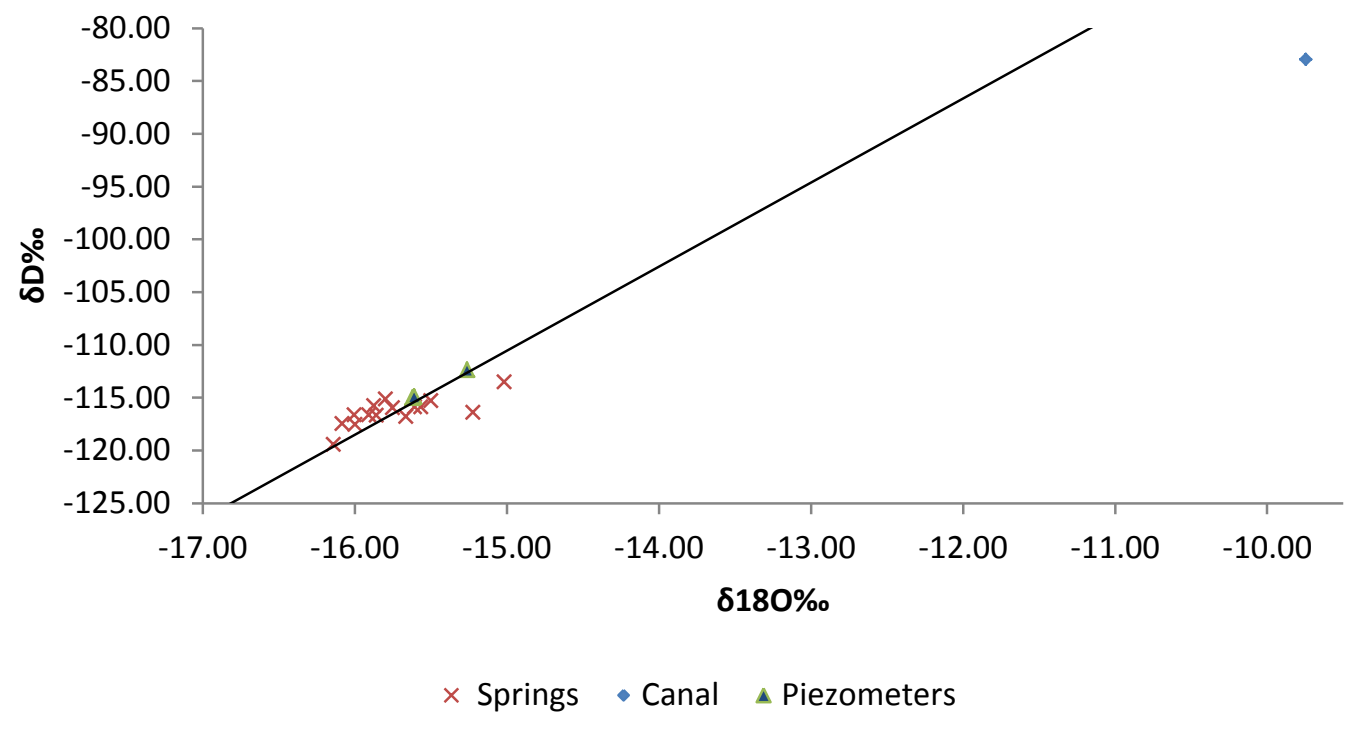

Figure 13: Isotopic ratio data for the springs, piezometers, and main canal in Round Meadow. While the springs were isotopically lighter than the piezometer samples, both plotted around the GMWL. The water in the main canal has taken on evaporative characteristics indicating storage at the surface.

\subsection{The Fen}

An area of diffuse groundwater discharge and neighboring areas of persistently high water table are present in the northwest corner of Round Meadow. This area is flanked on the south by an intermittent steam channel that drains a small butte located to the north (Figure 5). The area of diffuse groundwater discharge is a fen where in most years the potentiometric surface in the pumice aquifer is near the local ground surface throughout the growing season. This hydrologic condition supports an area of bryophyte growth and peat that is up to $1.1 \mathrm{~m}$ thick. An $8 \mathrm{~cm}$ diameter hole, mystery hole in Figure 14, inferred to be formed by piping from the pumice aquifer through the peat layer discharges water during the early summer in most years. The neighboring areas where 
the water table is persistently high are also characterized by the potentiometric surface for the pumice aquifer being within the organic-rich silt and rounded pumice-bearing alluvium above the pumice aquifer. Locally, this relation does support peat development, but in general these areas are characterized by deposition of organic-rich sediment. Bryophytes are locally present, but vegetation is dominated by sedges and rushes.

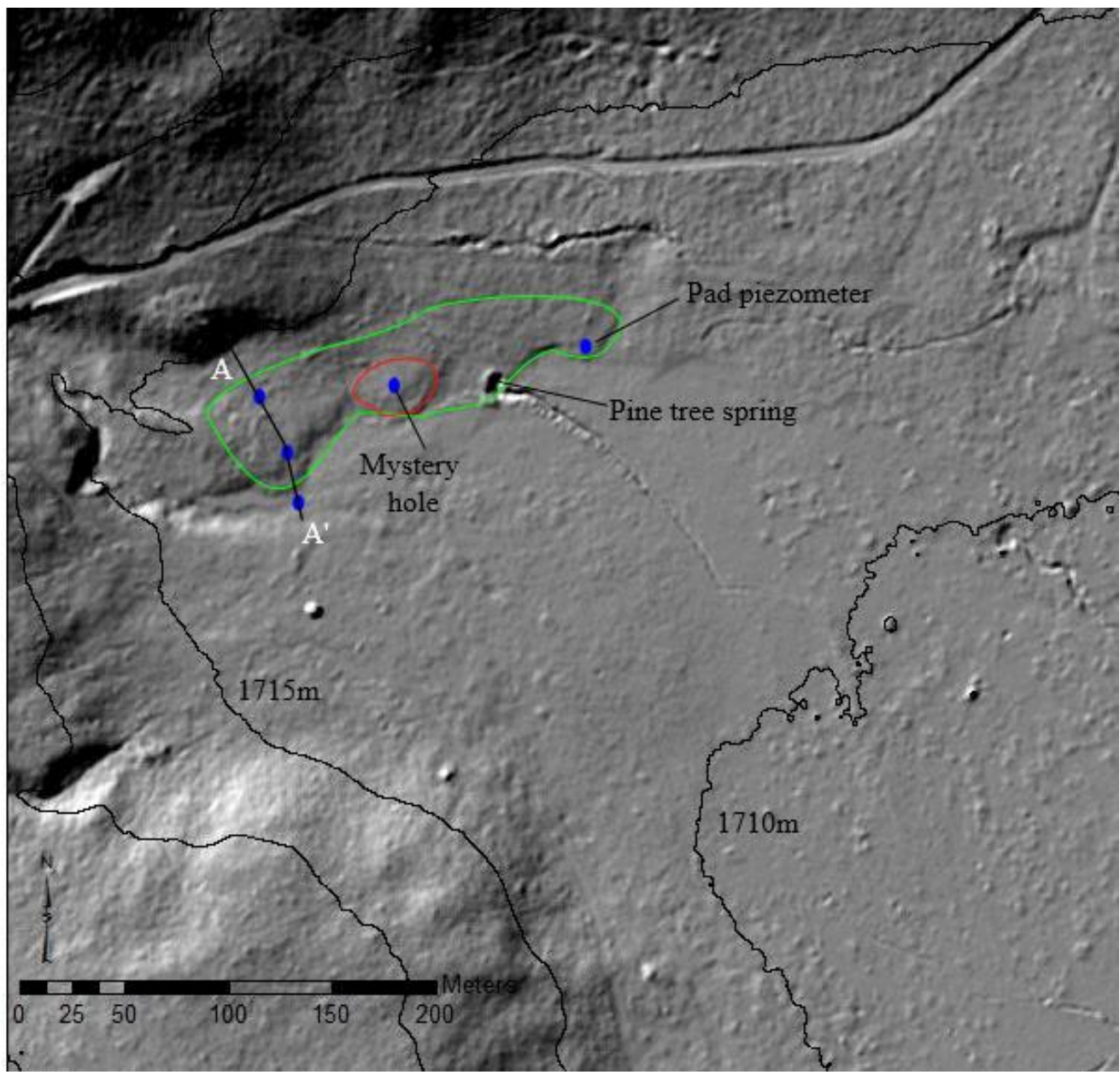

Figure 14: Fen area map. The green outline delineates the slightly elevated area with perennially high water table. The red outline within that surface marks the fen which is underlain by up to $1.1 \mathrm{~m}$ of peat. The cross section in Figure 15 is developed on the line from $A$ to $A^{\prime}$. 
The southern boundary of the fen and high water table area are marked by a low, south-facing berm. North of this berm the elevation is higher, persistently wet, and dominated by sedges and rushes. South of the berm is the channel of the intermittent stream. Here, the elevation is lower, the alluvium and pumice are dry, and about $30 \%$ of the ground surface is covered by vegetation. Three piezometers were installed at $30 \mathrm{~m}$ intervals to examine hydrologic conditions north and south of this berm. At the north end of the transect was outcrops of welded tuff. The ground surface dropped abruptly from the level of the outcrops to the area characterized by high water table. The ground surface dropped again by approximately $35 \mathrm{~cm}$ at the berm, as shown in Figure 15 . When holes were augered for 2 of the piezometers near the fen, the pad and the $60 \mathrm{~m}$, water rose to or near the surface when the pumice aquifer was penetrated. Core logs for the 4 borings in the fen area used to create this cross section can be found in Appendix E. 


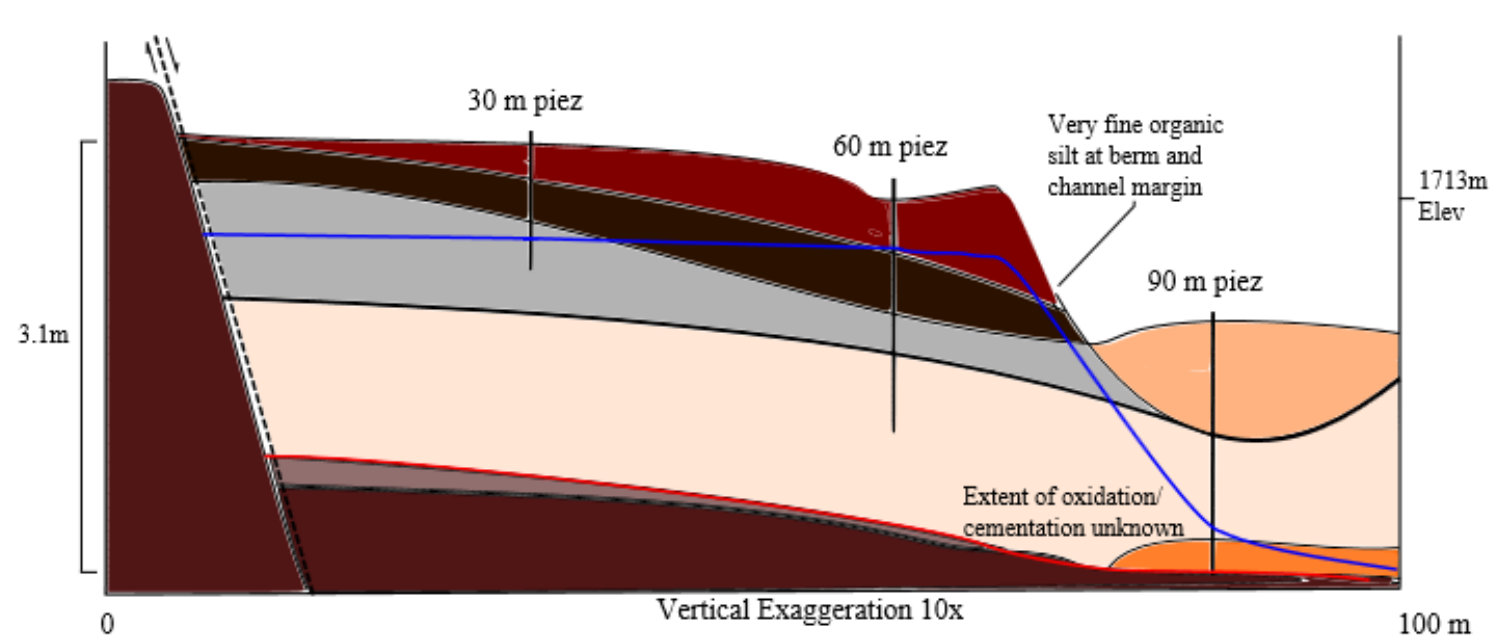

Holocene

Pliocene

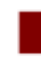

Organic-rich silt, rooted

Dark brown, organic-bearing silt

Silt rich with sub-rounded pumice, grey to white

Silt rich with sub-rounded pumice, yellow

Erosional upper contact of

Plinian fall pumice

Lower unit Plinian fall pumice.

Iron oxide stained to cemented

- Unconformity, pre-eruption surface

Figure 15: Cross section of the fen area. The water table drops sharply at the berm. On 17-May-2014 it was $37 \mathrm{~cm}$ below ground surface at the $60 \mathrm{~m}$ piezometer, and $171 \mathrm{~cm}$ at the $90 \mathrm{~m}$. Augering for the 90 $\mathrm{m}$ piezometer encountered oxidized pumice and refusal with scraping of rock. This was inferred to be the welded tuff which crops out about $90 \mathrm{~m}$ away.

Hydrographs for the three piezometers installed in this transect are presented in

Figure 16. The water table in the southernmost piezometer $(90 \mathrm{~m})$ located south of the berm is distinctly lower than the water table in the middle piezometer $(60 \mathrm{~m})$ located north of the berm. The berm is present along the entire southern edge of the wetland 
area. The berm is composed of organic-rich silt overlying silt with sparse to common grains of subangular pumice up to $1.5 \mathrm{~cm}$ in diameter. Both the $30 \mathrm{~m}$ and $90 \mathrm{~m}$ piezometers went dry in summer 2014.

There is a spring which forms a natural hole about $8 \mathrm{~cm}$ in diameter (dubbed the "mystery hole") near the center of the fen. This has been observed to flow with artesian pressure, although not during the drought of WY 2014 and WY 2015. The record for the mystery hole extends back to WY2010 when observations at Round Meadow started. Figure 16 contains hydrographs for the mystery hole within the fen and four piezometers located in the area of persistently high water table. 


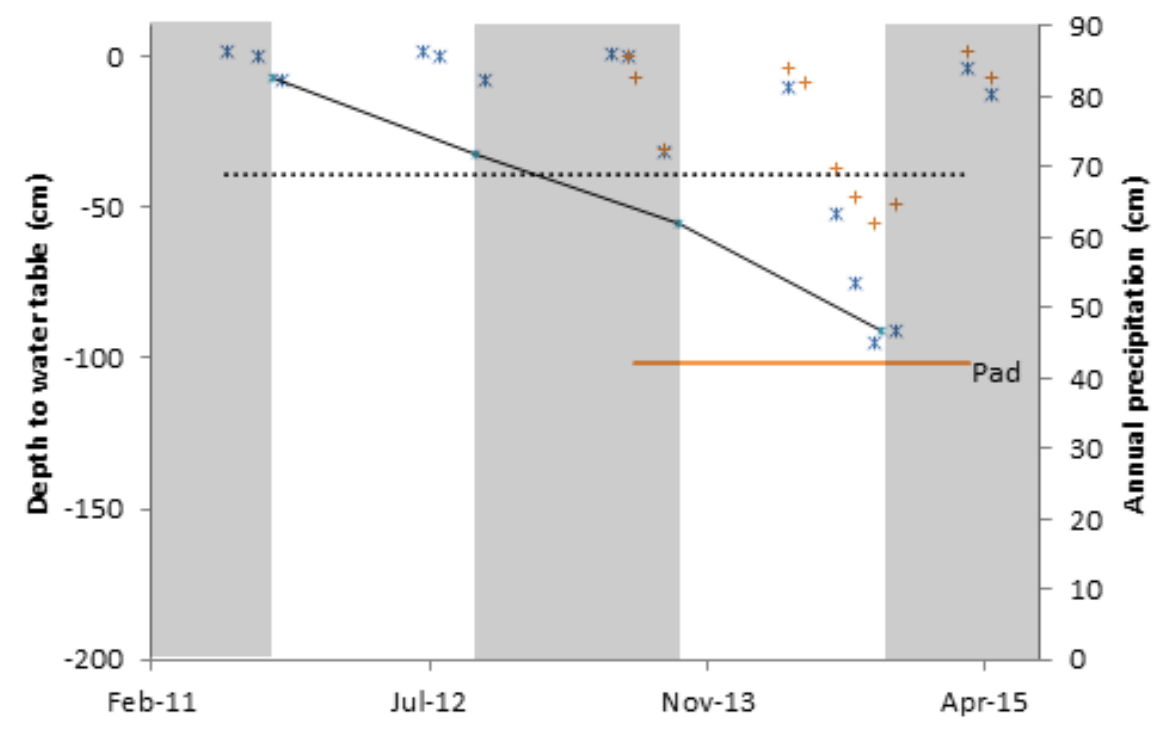

* Mystery hole + Pad — Precip .......... 30 year average

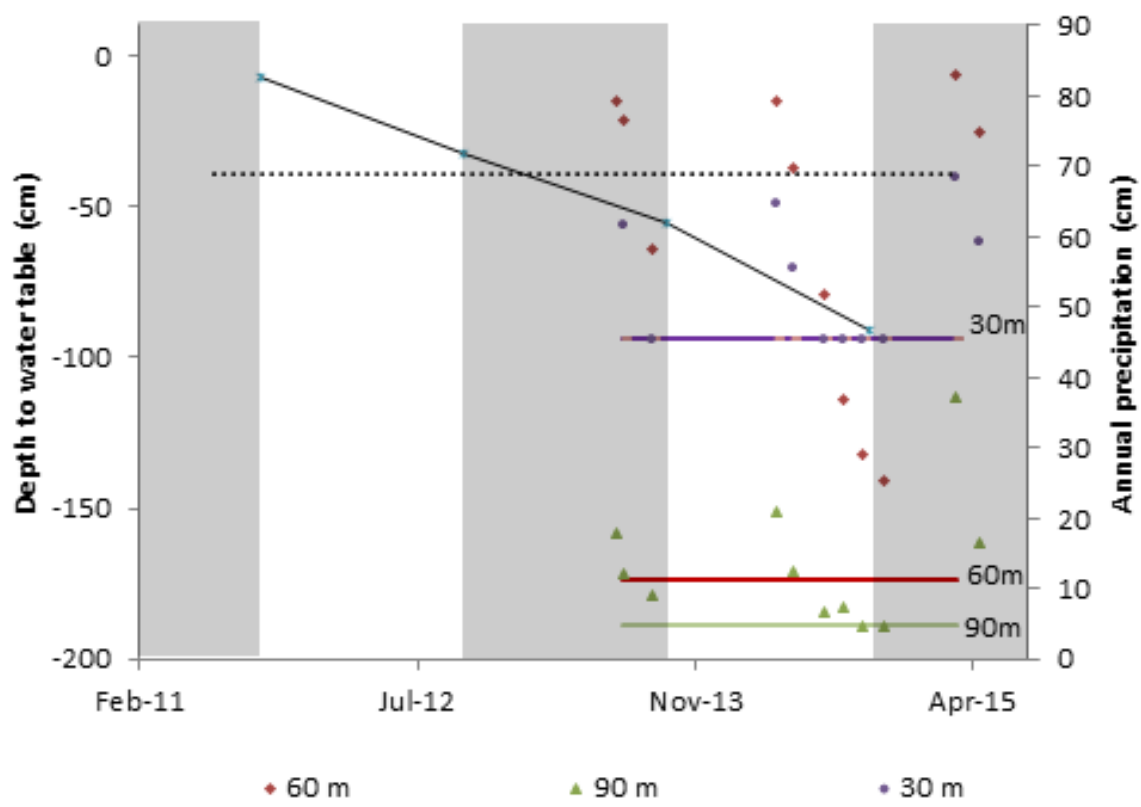

Figure 16: Hydrograph for the fen area piezometers. Two areas that had artesian pressure in wet years - the mystery hole and pad piezometer are shown at top, and the piezometer transect is shown at the bottom. The water table at the mystery hole follows the precipitation trend - in WY 2011-2012 it stayed within $15 \mathrm{~cm}$ of the ground surface, but by WY 2014 it had dropped to $95 \mathrm{~cm}$. The $30 \mathrm{~m}$ and the $90 \mathrm{~m}$ piezometers went dry in WY 2014, while the $60 \mathrm{~m}$ held water through the drought. 
Water in the mystery hole remained within $15 \mathrm{~cm}$ of the ground surface until fall 2013. The fen did not recharge in WY 2014 to even the lowest levels measured in WY 2012 and WY 2013. In September 2014 the water dropped to $95 \mathrm{~cm}$ below local ground surface which is approximately the maximum thickness of peat measured at the fen. In WY2015 the water level in the mystery hole has remained below the local ground surface.

About $50 \mathrm{~m}$ east of the mystery hole within the fen and $2 \mathrm{~m}$ lower in elevation is pine tree spring named for a solitary lodgepole pine tree at the edge of the excavated spring area. The spring discharges over a diffuse area within an excavated pit. A drainage canal has been excavated to the southeast of the spring and carries discharge from the spring toward the meadow. This excavated area and canal disrupt the natural channel of the intermittent stream than flanks the southern part of the wetland area. Until WY 2014 pine tree spring was interpreted to be an outflow feature of the fen. However, in the drought- stressed year the water level in the fen dropped significantly (Figure 16) while the flow from the spring remained consistent, indicating that the spring is fed by a different source than the fen.

\subsection{The Springs}

There are at least 3 springs that discharge into Round Meadow and are herein designated pine tree, cabin, and outlet spring. The locations of these springs are shown in Figure 17. 


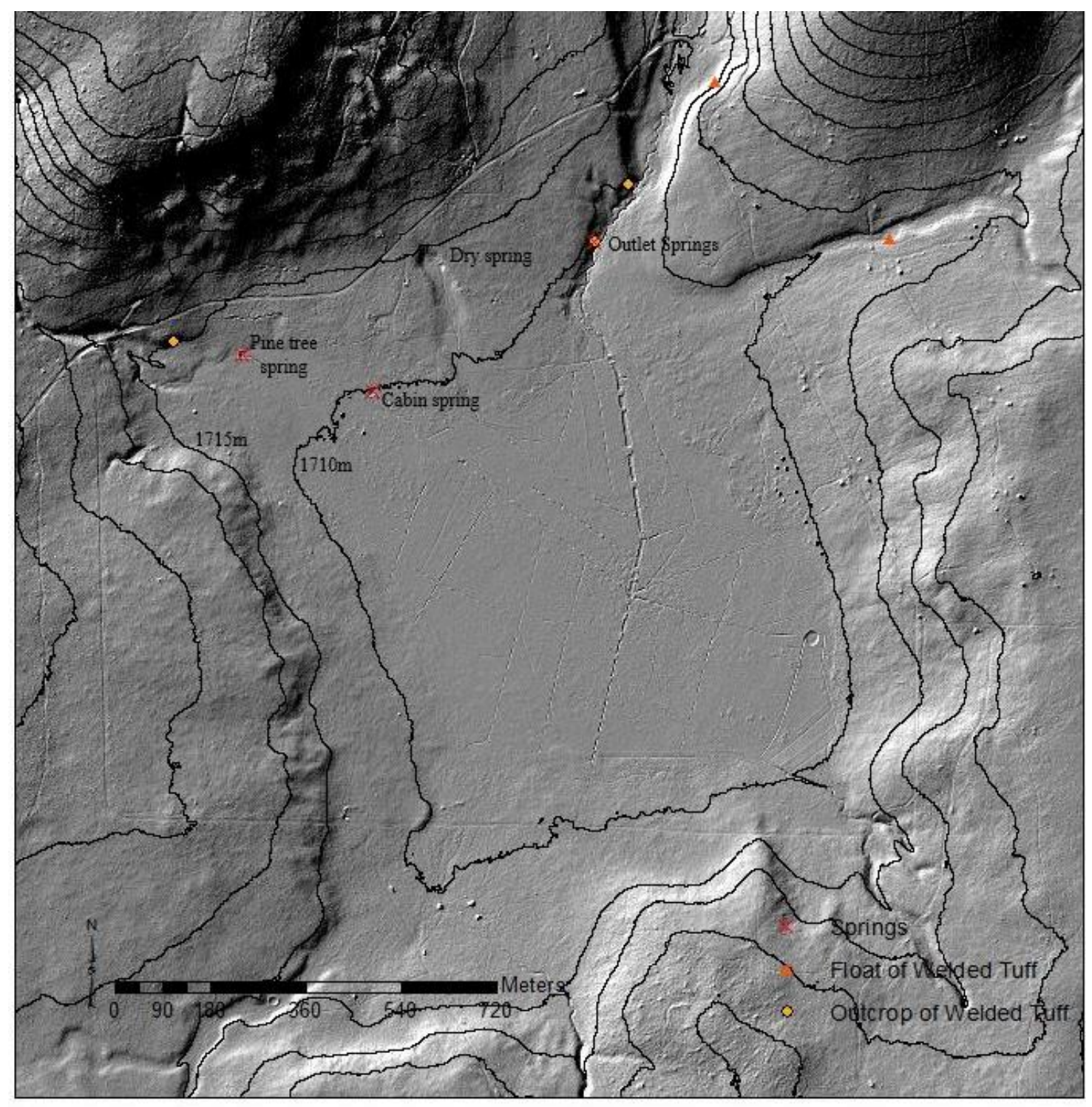

Figure 17: Area map of springs in Round Meadow, which are oriented similarly to the known outcrops of the welded tuff.

The springs are aligned approximately east-west along the northern margin of the meadow. Pine tree and outlet springs are proximal to outcrops of the phenocryst-poor welded tuff that are found along the northern margin of Round Meadow. Outcrops of 
welded tuff are present where the two orifices of the outlet spring discharge and welded tuff is present in the shallow subsurface where the discharges from the springs flows toward the Sellers Creek channel. The welded tuff does not crop out near cabin spring. The tuff is dipping slightly (approximately $2^{\circ}$ ) south based on the slope of the bench west of Sellers Creek in the outflow area, and it is not found in outcrop south of the locations shown on Figure 17. Since the springs have a similar distribution as the tuff outcrops at the northern edge of the meadow, it was inferred that the springs represent the surface expression of fracture flow within the bedrock.

Pine tree spring forms a small excavated amphitheater about $10 \mathrm{~m}$ across and $1.5 \mathrm{~m}$ deep (Figure 18). 


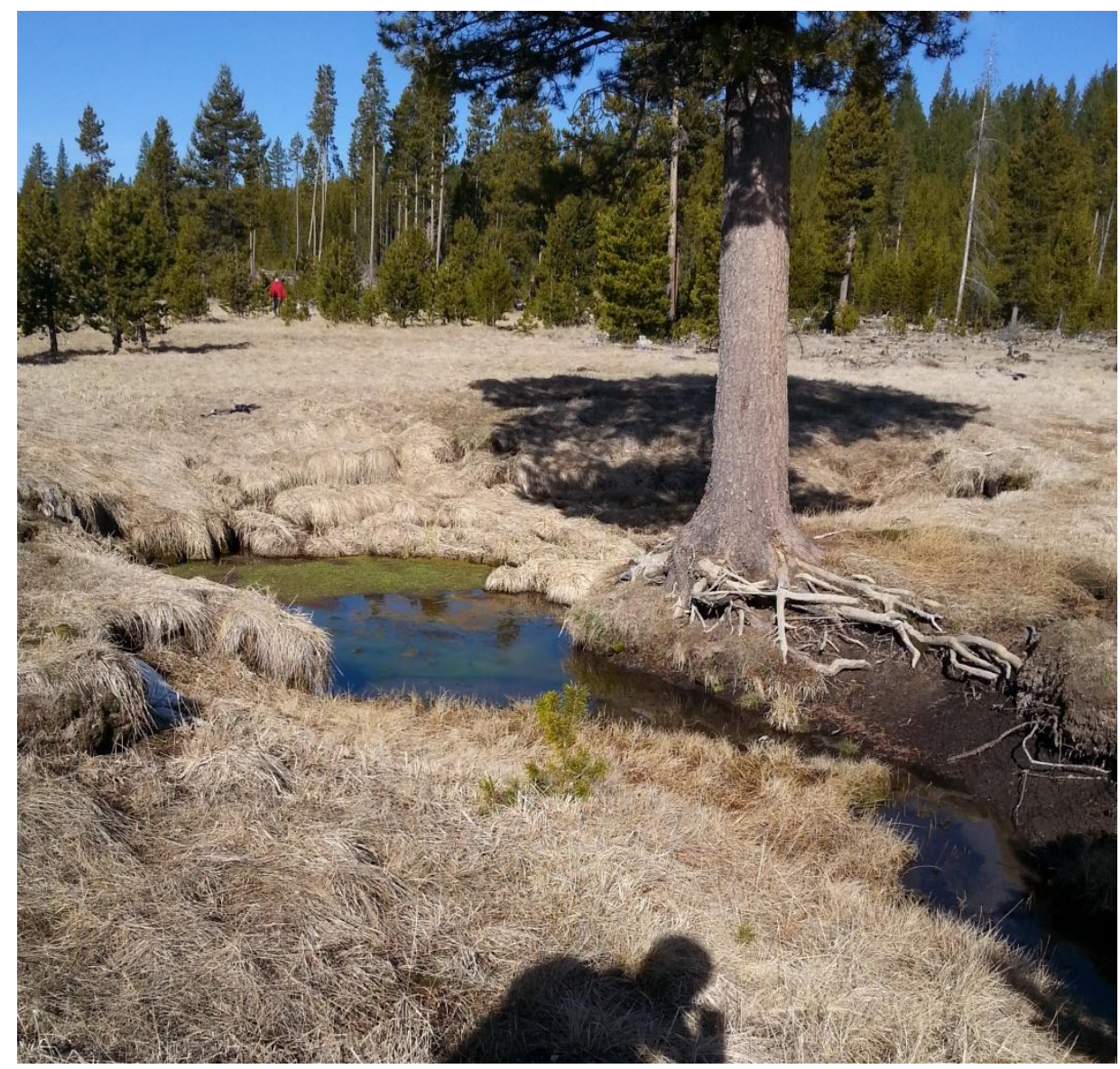

Figure 18: Photograph of pine tree spring. Excavation enlarged the spring pool and in normal water years there is diffuse discharge through the walls of the excavated area. The channel flowed for about $250 \mathrm{~m}$ into the meadow before dissipating throughout WY 2014. Photo facing approximately northnortheast

Diffuse discharge takes place across the floor, western, and northern walls of the excavated area. However, during WY2014 drought years, flow decreased and ceased from the walls, but persisted through the floor such that discharge from the spring through the excavated outflow canal persisted. Measured discharge ranged from 0.001 $\mathrm{m}^{3} / \mathrm{s}$ to $0.002 \mathrm{~m}^{3} / \mathrm{s}$. The water seeping through the west and north wall are inferred to source from the fen during non-drought conditions. In WY2014 the persistent discharge 
through the floor of the excavated area and the cool water temperatures suggest discharge from a deeper source. Pine tree spring discharges to a canal that flows to the southeast for an estimated $250 \mathrm{~m}$ before dispersing into the meadow from the end of the canal.

The cabin spring also forms a semi-circular excavated pool, but with banks that are only about $10 \mathrm{~cm}$ high. The north wall of the excavated area is underlain by peat that is up to $52 \mathrm{~cm}$ thick. A concrete spring ring and wooden platform were installed in the spring by previous users and this is where all samples from the spring have been obtained. Discharge is diffuse over the excavated area where the spring box was installed. However, within this excavated area focused discharge occurs where rising water deposits small grains of pumice around the orifices (Figure 19). The location of these discharge points is not consistent. 


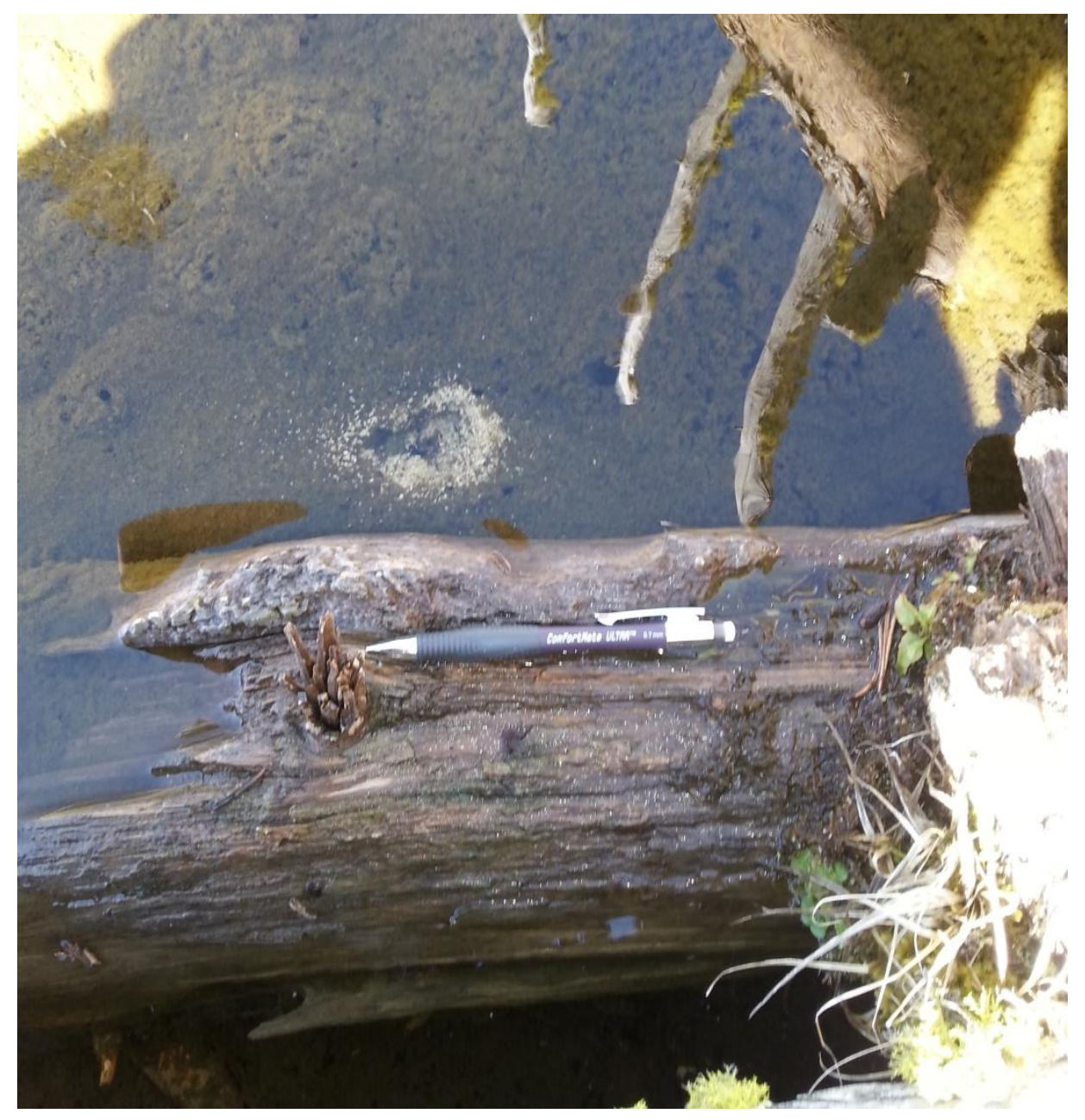

Figure 19: Close up photograph of cabin spring showing pumice grains being pushed to the surface by flow. Other holes in the sediment nearby may have been sites of earlier discharge.

The cabin spring flows southeast through a canal into the meadow where discharge either evaporates or soaks into the aquifer. The north canal piezometer was installed within $7 \mathrm{~m}$ of this channel (611542 E, $4798743 \mathrm{~N}$ ) in July 2014 to monitor the depth to the water table relative to the channel. In July there was a $48 \mathrm{~cm}$ discrepancy between the water table and the channel and this gap continued to widen in WY 2014. The outflow canals from both pine tree and cabin spring are perched relative to the pumice aquifer in the northwestern part of the meadow. These data indicate that at 
least in drought years the storage in the meadow and the water in the spring channels are not connected.

A north-south valley with a naturally occurring, approximately $3 \mathrm{~m}$ high, amphitheater-shaped head scarp is located northeast of the cabin spring (Figure 17). An auger hole drilled in what appears to be a discharge point in the focus of the amphitheater penetrated $38 \mathrm{~cm}$ of silt with rounded pumice grains and gravel containing pebbles dominated by welded tuff before refusal. Discharge from this feature has not been observed during six years of monitoring. It is interpreted to be a seasonal spring where groundwater moving downslope on welded tuff bedrock breaks surface. This seasonal spring is interpreted as distinctly different from pine tree, cabin, and outlet springs.

The two orifices at the outlet spring discharge from under overhanging fluvial sediment and are floored by welded tuff. The combined outflow channel is floored by welded tuff covered by an estimated $3 \mathrm{~cm}$ to $10 \mathrm{~cm}$ of sediment. The bedrock is present at least to the confluence with Sellers Creek, $10 \mathrm{~m}$ from the springs. The two orifices are approximately $5 \mathrm{~m}$ apart but are interpreted to be physically related based on proximity, similar water temperature, and electrical conductivity. The combined discharge from the springs was determined by gaging Sellers Creek above and below the confluence and was assumed to be the difference in the discharge values. The discharge from these springs ranged from $0.02 \mathrm{~m}^{3} \mathrm{~s}^{-1}$ to $0.007 \mathrm{~m}^{3} \mathrm{~s}^{-1}$ from April to October. This discharge does not enter the meadow, but joins Sellers Creek and runs out toward the culvert at FSAR 
9405. The discharge from pine tree, cabin, and outlet springs remained consistent relative to the culvert (Figure 20 and Table 6) during WY2014 and March in WY2015 despite the drawdown of storage in the basin.

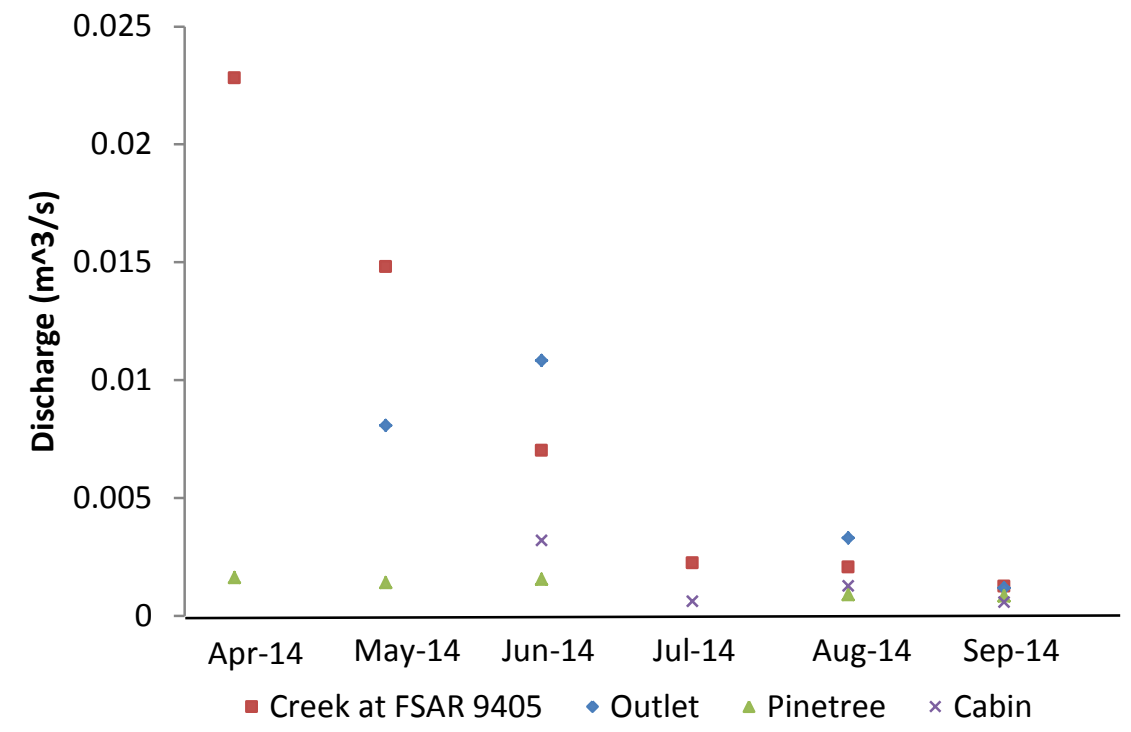

Figure 20: Measured discharge of the 3 springs compared to Sellers Creek

Table 6: Coefficients of variation for the discharge at 3 springs and flow at Sellers Creek. Outlet spring discharge was more difficult to gage, and would be $\mathbf{0 . 5 2}$ with the unexpectedly high reading in June omitted.

\begin{tabular}{lcccc}
\hline Discharge location & Creek at FSAR 9405 & Pine tree spring & Cabin spring & Outlet spring \\
\hline \hline $\begin{array}{l}\text { Coefficient of } \\
\text { variation Apr-Oct, } \\
2014\end{array}$ & 0.96 & 0.16 & 0.29 & 0.75 \\
\hline
\end{tabular}

The water temperatures of all 3 springs are colder in the summer and warmer in early spring than the temperatures measured in piezometers and the northwest fen. 
Temperature data for springs and piezometers are presented in Figure 21 for WY2014

and WY2015. Electrical conductivity in the springs remained consistently low (30-50

$\mu \mathrm{S} / \mathrm{cm}$ ) throughout the dry season, while average conductivity in the piezometers

tended to increase through the summer (Figure22).

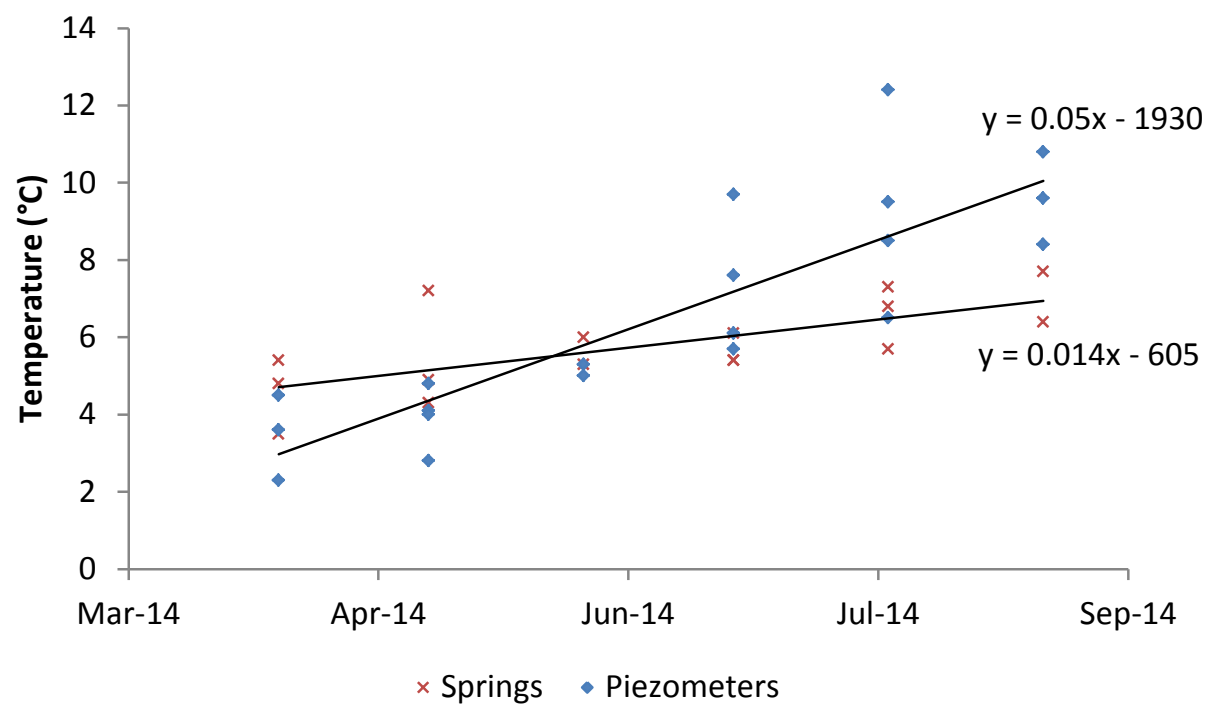

Figure 21: Temperature measurements from April to October 2014 for the springs and piezometers in Round Meadow. Water in the pumice aquifer was cooler than the springs in April but warmed to nearly $10^{\circ} \mathrm{C}$ by fall, while discharge from the springs remained between $5^{\circ}-6.5^{\circ} \mathrm{C}$ during the same period. 


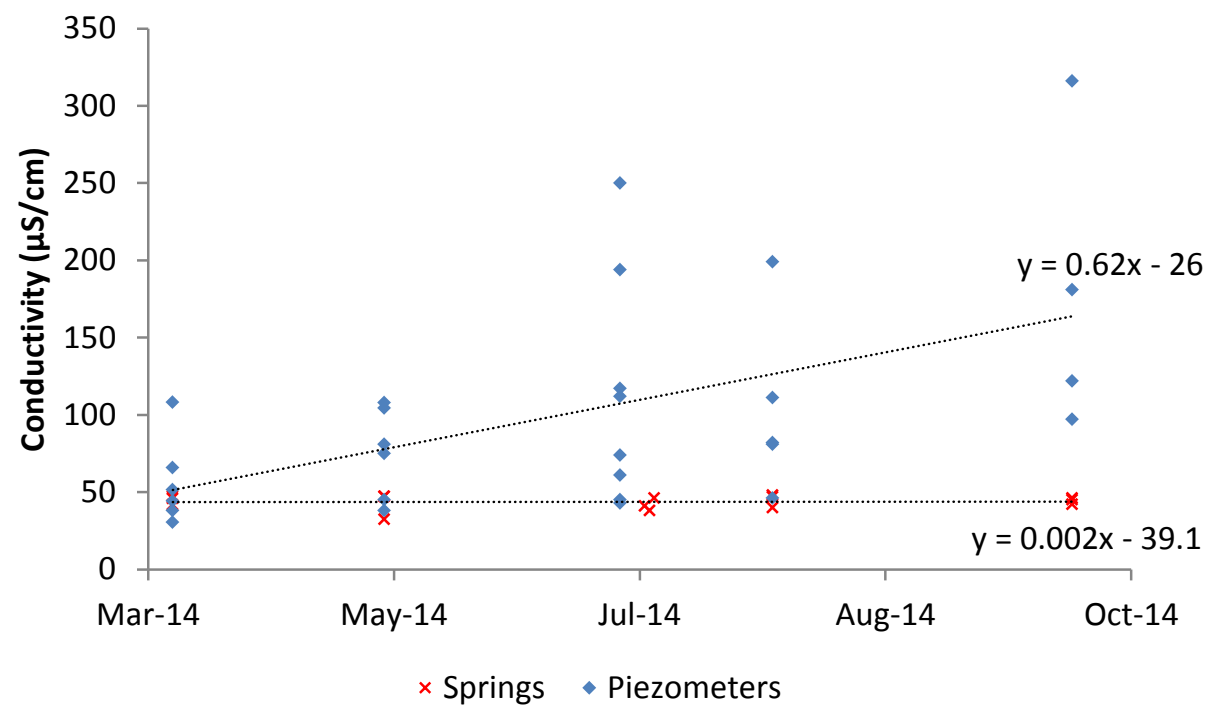

Figure 22: Conductivity measurements from April to October 2014 for the springs and piezometers. Conductivity for water in the pumice aquifer rose steadily through the season, while conductivity for the springs was essentially unchanged.

\subsubsection{Stable Isotope Analysis}

The samples from the springs at Round Meadow were compared to samples

from the spring at the fen near FSLR 460. The 460 spring is the nearest known spring to Round Meadow, about $3.2 \mathrm{~km}$ south and the samples were compared to help determine whether the springs shared a common recharge source. When plotted, all of the spring samples are clustered at the lower end of the GMWL (Figure 23). Throughout the sampling season, these were consistently isotopically lighter than either the piezometer or surface water samples. The water from the 460 fen spring plots near the other springs, but appears to form a subgroup that is slightly heavier than the Round Meadow springs. The similarity of the samples is evaluated using a double-sided t test below. 


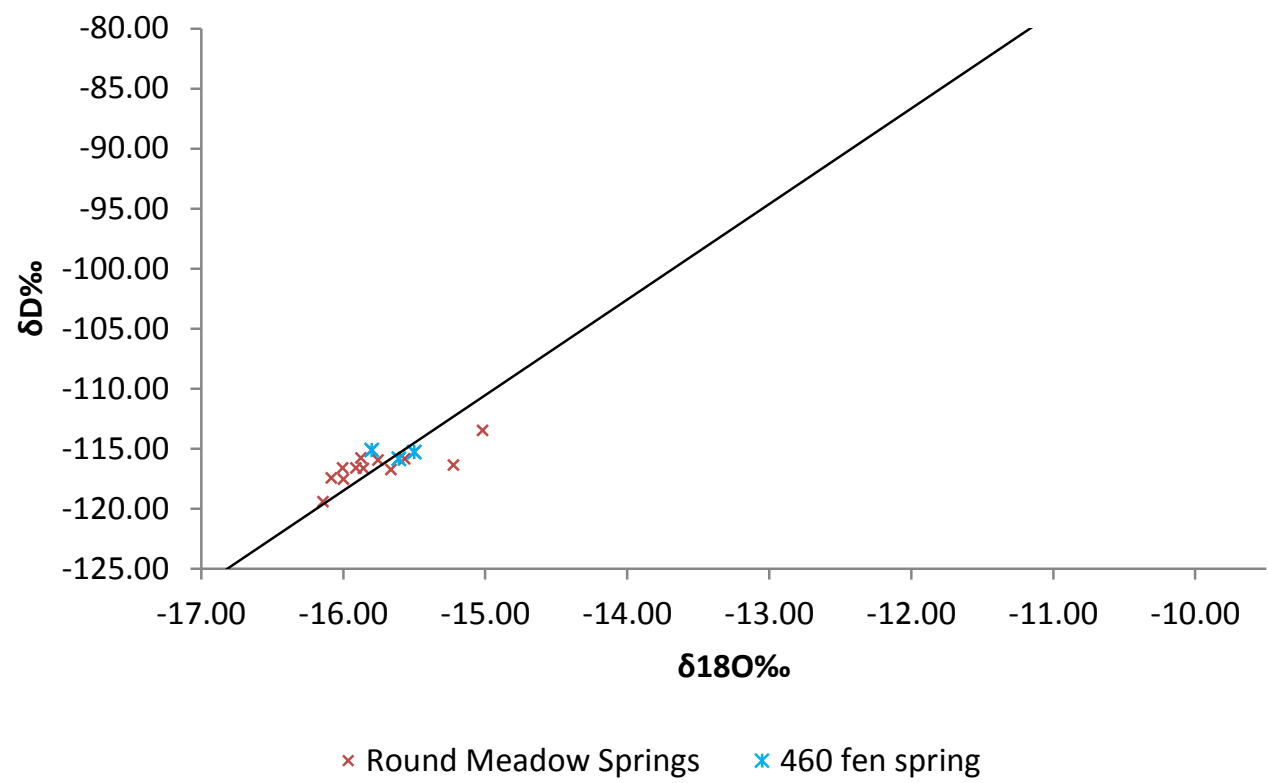

Figure 23: Results of isotopic analysis for the Round Meadow and 460 fen springs. The waters are isotopically similar. Although the $\mathbf{4 6 0}$ spring was slightly higher in the heavier $\mathrm{O}$ and $\mathrm{H}$ isotopes, the springs are more similar to each other than to water in the pumice aquifer.

The t-statistic test for differences in means and variance yielded a probability of .17 for outcomes in the tail of the distribution, or a likelihood of about $83 \%$ that the samples are from the same population. Since the probability that they are different is greater than $5 \%$, we cannot state unequivocally that the spring water at the 2 locations is the same within our given acceptable error, but they are similar enough that minor heterogeneities in the natural system could account for the differences.

Two of the spring samples are shifted below the GMWL, and these are the late season (September and October) samples from cabin spring. The spring discharges into a low-relief excavated depression and it is interpreted that the water from the spring was mixing with water that was being evaporated at the surface. These data will be used 
along with the canal and creek samples to help establish an isotopic evaporative curve for Round Meadow.

\subsection{Outflow}

The Round Meadow basin drains through a topographically low confluence area at the northeast corner of the meadow that is the source for Sellers Creek. From the confluence area Sellers Creek flows northward and the elevation of the valley floor drops $5 \mathrm{~m}$ from the confluence to FSCR 9405 where the flow is focused through a culvert. The confluence area is a crucial area for understanding the hydrogeology of Round Meadow, however, human activity has obscured key relationships. Chief among these is the termination of the central canal that carries water from the meadow to the confluence area. Figure 24 provides the location of key features described below. Several barriers have been installed within the central canal with the northernmost constructed of rocks and soil at the "dam" site. 


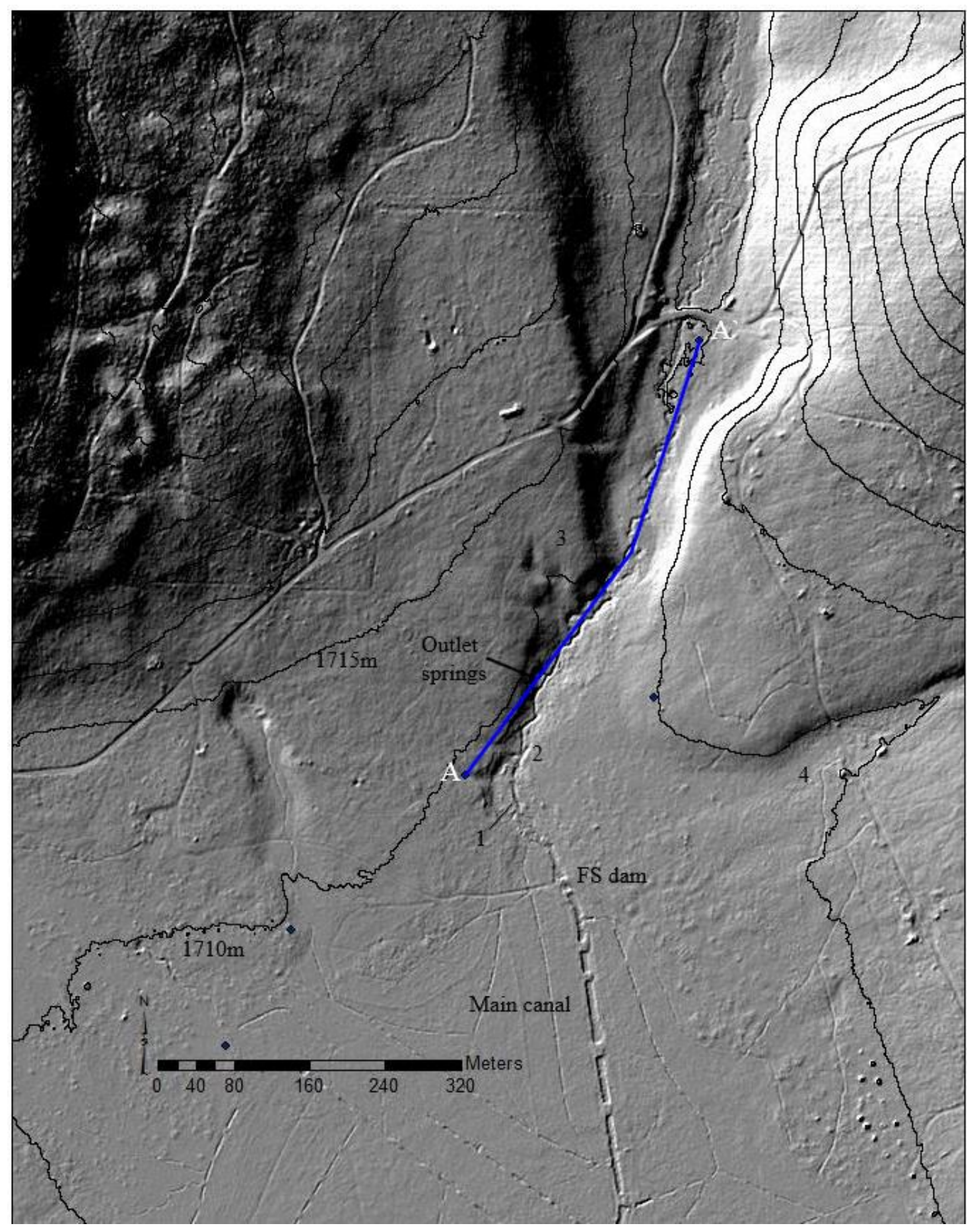

Figure 24: Map for the outflow area. 1: flat perennially water-inundated area north of the Forest Service dam. 2: knickpoint for the meadow and the beginning of Sellers Creek. 3: gently south-sloping $\left(2^{\circ}\right)$ bench that is inferred to be formed by the welded tuff. Past this point the creek bends northward and changes in morphology to a more meandering character. 4: outlet of an intermittent stream that formed the fan east of Sellers Creek in the confluence area. 
When water is high enough in the meadow water is able to pass to the west of this blockage and flow into Sellers Creek. Between this blockage and point 1, the canal is wider ( $3 \mathrm{~m}$ to $10 \mathrm{~m}$ ) and contained water throughout WY2014 at the same elevation as south of the barrier. During normal water years there is diffuse flow through the side of the low $(50 \mathrm{~cm})$ terrace that runs northwest from the Forest Service dam (Figure 24). This terrace is an erosional feature cut into the alluvium that overlies the pumice aquifer, which suggests that water flowed relatively rapidly during the spring freshet.

I have selected point 2 as the approximate starting point for Sellers Creek. In this area, probing with metal rods indicates that the welded tuff is near the ground surface and forms a knickpoint that controls the elevation at the head of the creek. In WY2014 the water table in the meadow declined below the knickpoint. Pressure transducers were installed in two piezometers in the meadow to monitor ground water levels. From the time of installation in July-2014 decrease in the water column is noted by decreasing pressure. The minimum was reached in middle September-2014. The data from the pressure transducer for WY2015 are presented in Figure 25 for the vibracore piezometer. Included in Figure 25 is the curve for cumulative precipitation for the Chemult Alternate SNOTEL site. The increase in pressure through the fall accompanied rising water table and flooding of the meadow. The flattening of the curve in middle December 2014 coincided with a large precipitation event and is interpreted to indicate discharge from the meadow over the knickpoint started. Subsequent to this overtopping 
added precipitation is noted by fluctuating of the water level in the piezometer around a common value.

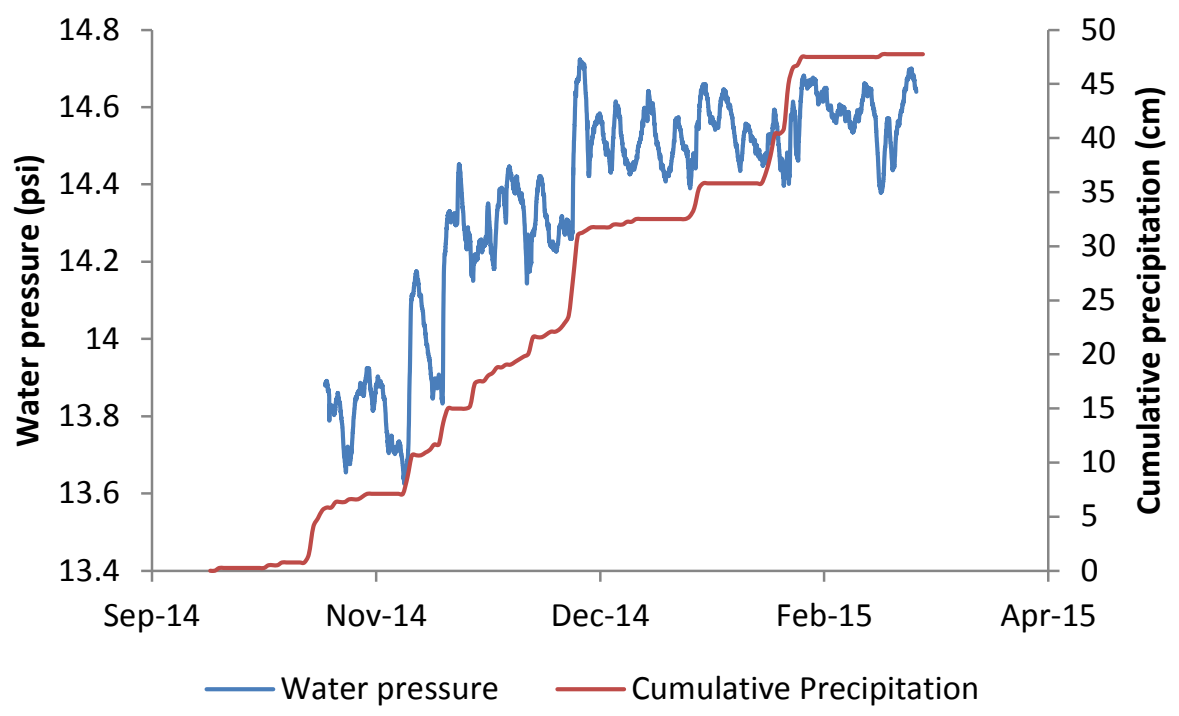

Figure 25: Water pressure in the vibracore piezometer and cumulative precipitation during winter of WY 2015. The period beginning in December 2014 when increased precipitation did not increase water level in the piezometer is inferred to be the time when storage in the meadow was overtopped and water could flow over the knickpoint.

Two additional features lend complexity to the confluence area. These are 1) the southward slope of the land surfaces to the east and west of Sellers Creek and 2) the channel and fan at the mouth of an intermittent stream that joins the meadow and creek in the confluence area.

The ground surface along the entire northern margin of Round Meadow slopes to the south and merges with the surface elevation of the meadow. In the confluence area this sloping surface is prominent (Figure 24) and is present on both sides of the Sellers Creek valley. Auger holes have been drilled in this surface to determine its 
composition. In nearly all holes a layer of glassy silt with rounded grains of pumice and crystal-rich sand overlie the coarse-grained upper pumice unit (Figure 26). Where this layer is absent the upper pumice unit is at the surface. The slope of this surface is similar to the dip of the welded tuff that underlies the north flank of the meadow. However, the slope is opposite the slope of the Sellers Creek valley which cuts through the pumice layer to the welded tuff. Core logs for 3 of the borings used to create this cross section can be found in Appendix E. 


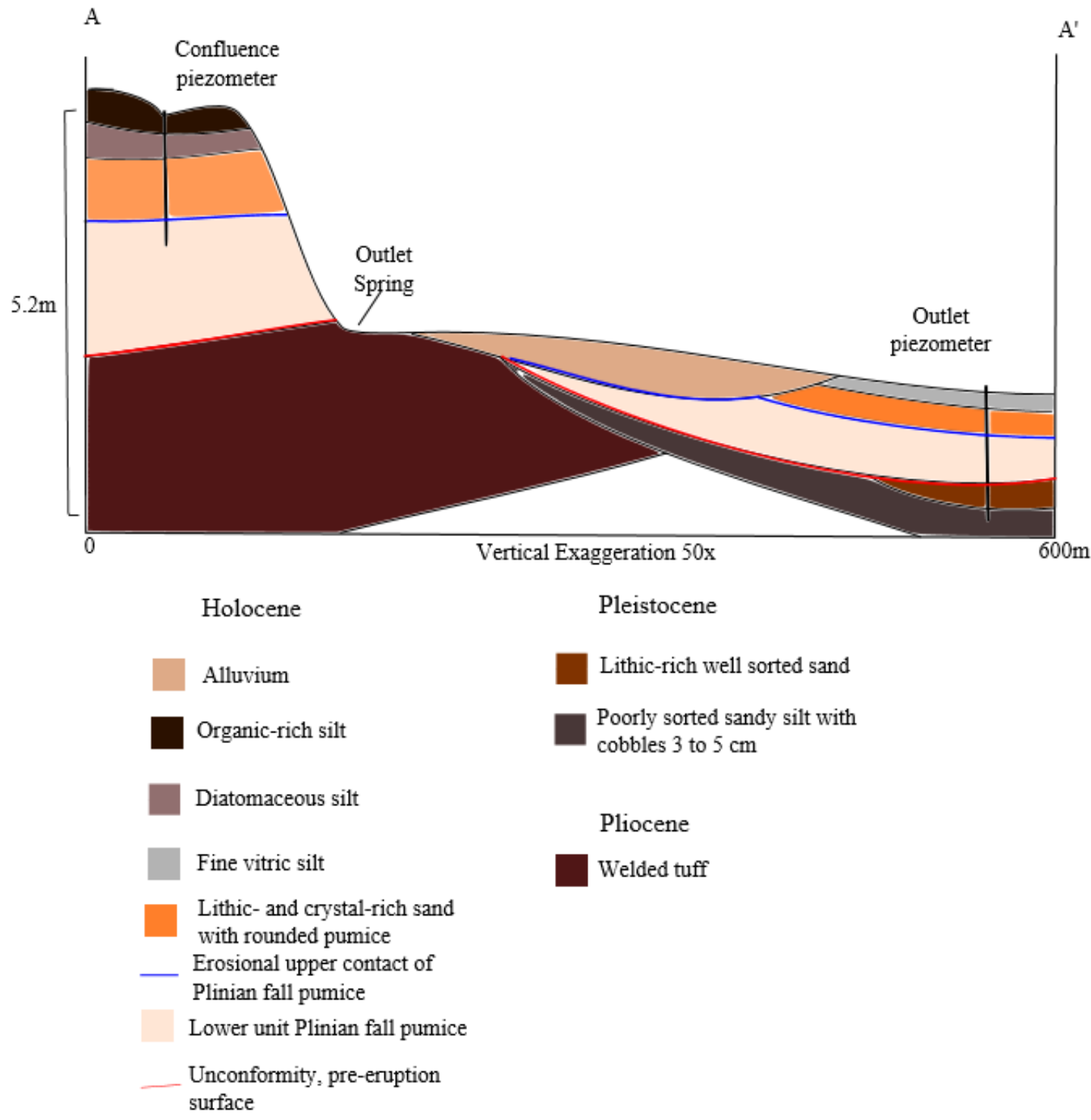

Figure 26: Cross section of the outflow area from the confluence piezometer to the outlet piezometer. Sellers Creek flows on the welded tuff bedrock near the outlet spring, but the subsurface sediments are alluvium overlying Plinian fall pumice to the north.

The second complexity is related to the channel that enters the confluence area

from the east, at point 4 on Figure 24 . The channel cuts into the south sloping surface described above and is underlain by alluvium over the lower pumice. The surface formed by the floor of the valley does not extend to the west side of Sellers Creek in the 
confluence area, but wraps around a remnant of the south sloping surface on the east side of the creek.

The geomorphology of the confluence area suggests the following geomorphic history. 1) After the eruption, Sellers Creek was blocked at the confluence and the south facing slope along the northern edge of Round Meadow developed by fluvial process eroding into the pumice and depositing a layer of glassy silt with rounded pumice and crystals across the south sloping surface. The slope on this surface was controlled by the dip on the underlying welded tuff. 2) The intermittent stream valley entering the confluence area from the east began to cut into this south sloping surface and in the area of the buried Sellers Creek valley began to cut through the blockage in the valley. 3 ) Rising water level in the meadow contributed to the overtopping allowing down cutting of the head of Sellers Creek to the elevation of the knickpoint.

Downstream from the confluence the channel is oriented NNE, but swings more northerly after the last outcrops of welded tuff in this part of the valley. In the NNE section and starting about $100 \mathrm{~m}$ south (611857 E, $4799104 \mathrm{~N}$ ) of the outlet spring, a steel rod pushed into the creek bed encountered bedrock at less than $1 \mathrm{~m}$. The creek is flowing on the welded tuff through this section, as shown on the cross section (Figure 26). Where the channel swings to a more northerly direction, topography flattens slightly and the creek takes on a meandering pattern just after it crosses the north-south trending bench formed by the welded tuff. Given the southerly dip of the welded tuff, it is inferred that the more northerly trending reach of Sellers Creek may be underlain by 
stratigraphic units that underlie the welded zone of the tuff. This could be the unwelded base of the tuff or units that predate the eruption of the welded tuff.

Discharge measured in Sellers Creek upstream from the outlet spring in late summer after discharge from the meadow had apparently ceased suggested one or more springs discharge to the creek between the outlet spring and the knickpoint. This is a gaining reach for Sellers Creek. However, discharge at the culvert at FSCR 9405 is lower than at the gaging point below the confluence with the outlet springs and Sellers Creek suggesting that reach is a losing reach for Sellers Creek (Figure 27).

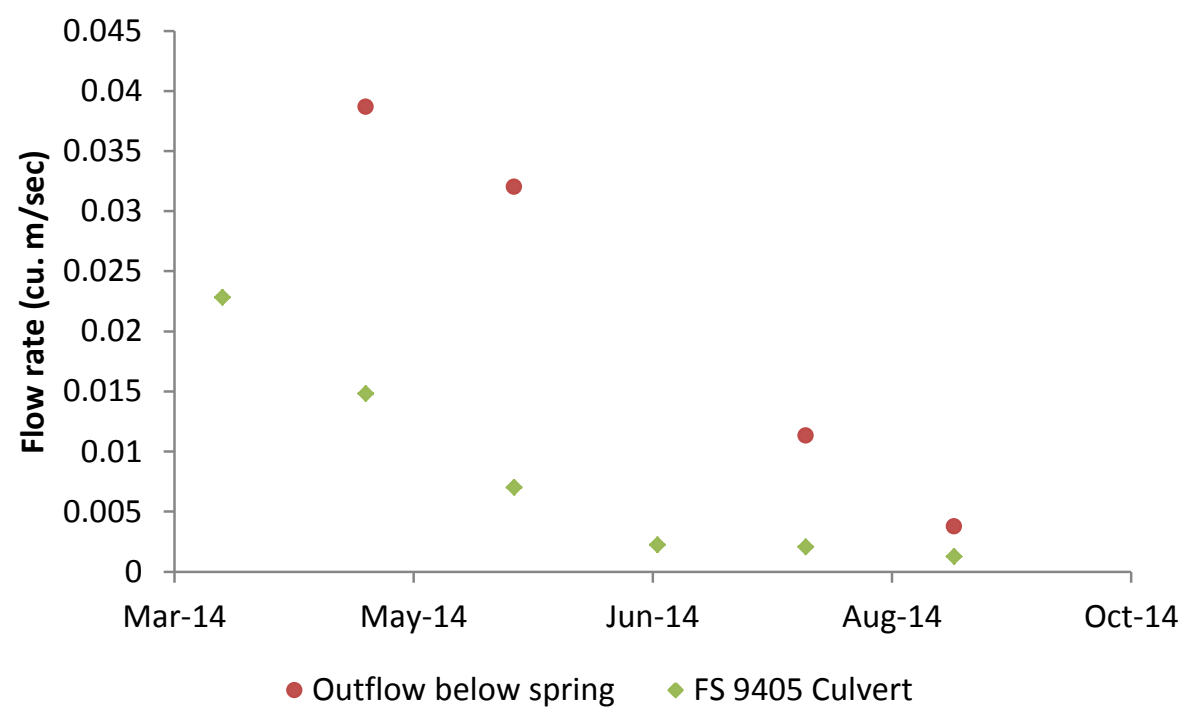

Figure 27: Flow rates for Sellers Creek north of the outlet spring and at the culvert show the reach downstream of the spring is a losing reach.

Hydrographs for the confluence and outlet piezometers indicate that water levels in the outflow area were less responsive to changes in yearly precipitation than in 
the fen or meadow (Figure 28). Although the water levels did decline over the study period, there was less variability between wet and dry years. The outlet had only a $29 \%$ difference between the low point in WY 2011 and the low point in the drought year of WY 2014. The outflow area is topographically lower than the other components and is drained by Sellers Creek. It was inferred that there is less potential for storage in the outflow area, but also less decline in drought years due to input from Sellers Creek. 

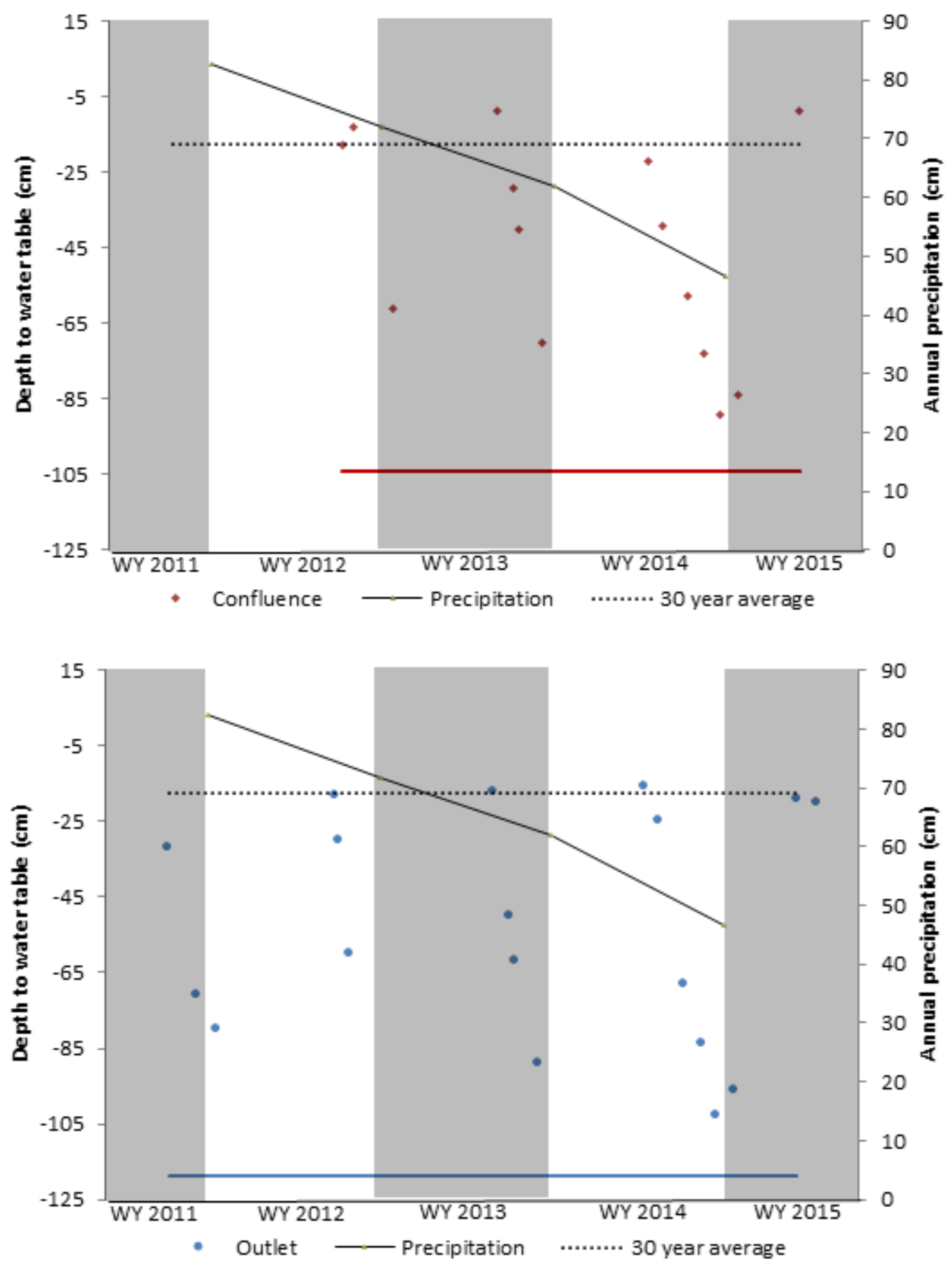

Figure 28: Hydrograph for the confluence and outlet piezometers. Water levels in the outflow area show less year to year variability than the other components of the meadow system. The red and blue solid lines near the bottom represent the depth of the bottom of the confluence and outlet piezometers respectively below local ground surface. 


\subsubsection{Stable Isotope Analysis}

Isotopic analysis of Sellers Creek at the FSAR 9405 road helps clarify the fluxes and storage in the system from spring to fall. In May the isotopic ratio at the culvert showed strong evaporative characteristics (Figure 28) indicating that surface water in the meadow was contributing significantly to flow to the stream. By July and September the evaporative trend had disappeared and the isotopic character for the creek was nearly the same as the outlet spring, indicating that the contribution from the meadow had dwindled or ceased. Despite the drop in contribution from the meadow, there is perennial flow in Sellers Creek above the outlet spring. In October the isotopic ratio had shifted below the GMWL again, although less so than before. There were two effects in the late summer and fall that probably contributed to this shift. First, although there was no visible flow from the meadow, the water that was left in the canal had a highly evaporative isotopic character (Figure 29) which mixed with the lighter spring water to give an intermediate sample at the culvert. Second, flow through the creek was at a low point in the late season (Figure 26) and longer transit time through the valley may have caused increased evaporation.

The data for the surface water samples, including the contribution from the cabin spring that likely evaporated in the spring basin were used to establish a local evaporative line for the basin (Figure 29). The slope is consistent with evaporative lines for evaporative irrigation water analyzed elsewhere in the Klamath basin (Palmer et al., 2006). 


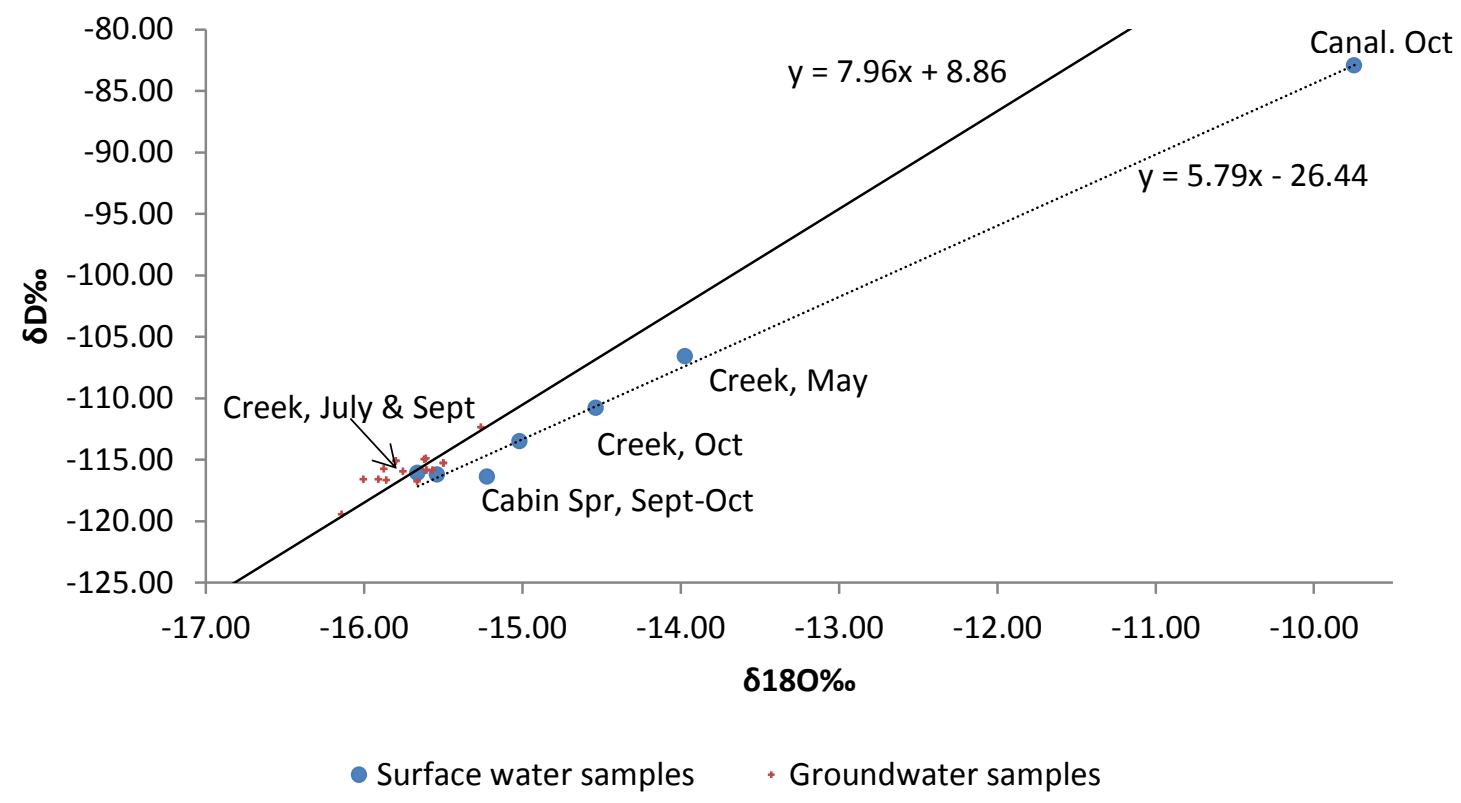

Figure 29: Isotopic ratios for groundwater and surface water samples showing the slope of the evaporative line at Round Meadow. The isotope data also tracks the trend of early season input to the creek from the meadow slowing through the summer as the isotopic ratio in the creek resembles that of the outlet spring.

\subsection{Water Budget}

\subsubsection{Precipitation}

The topographic setting of the Round Meadow system at the divide between the Deschutes and Klamath river basins reduces the input terms to those describing precipitation and groundwater. In WY2014 the largest source of water entering the Round Meadow system was from precipitation, the majority of which typically falls as 
snow, according to the 30-year averages. This was the case in WY2014, but in WY2015 about $90 \%$ of the precipitation was rain. Since the area is not readily accessible during the winter months, the actual input and output through the basin were not measured, so several methods were used to estimate storage and drainage. The precipitation estimate for Round Meadow was constructed from data provided by 1) Snotel Chemult Alternate site 395, and 2) PRISM Explorer.

Precipitation at the Snotel Chemult Alternate site 395 for WY2014 beginning 1October-2013 and shown in Figure 30 was the starting point for the precipitation estimate. The SNOTEL site is located approximately $18 \mathrm{~km}$ from Round Meadow and at 230 m lower elevation. Walker Rim, a 700 m fault escarpment, lies between these two sites and impacts precipitation by orographic lifting. Thus, the amount of precipitation received at Round Meadow is greater than the measured value at the Chemult Alternate site. During WY2014 the cumulative precipitation at the Chemult Alternate SNOTEL site was $467 \mathrm{~mm}$. 


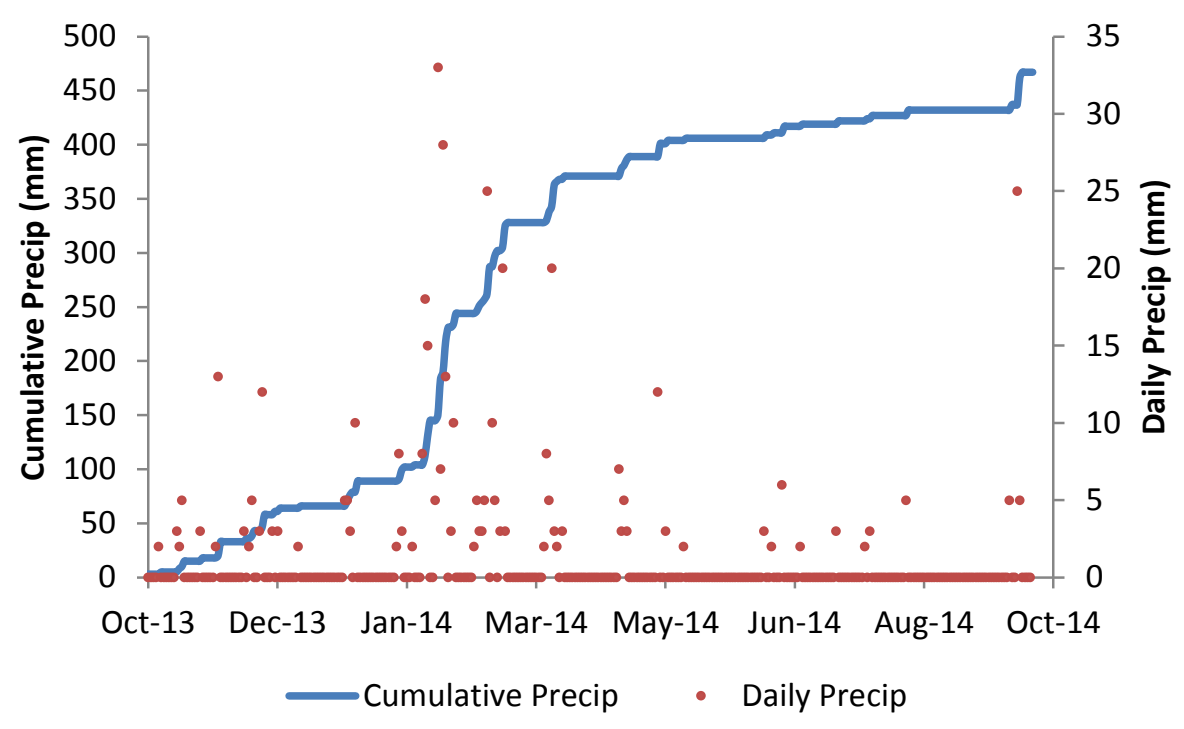

Figure 30: Cumulative and daily precipitation from WY 2014 measured at the Chemult Alternate Snotel station. Total precipitation was $\mathbf{3 0} \%$ less than the $\mathbf{3 0}$ year average for the site.

The Oregon State University PRISM data explorer was consulted. PRISM is a gridbased computer model which aggregates weather data from approximately 13,000 meteorological stations in the United States. The model interpolates onto a 30 arcsecond grid (approximately $800 \mathrm{~m}^{2}$ at $40^{\circ}$ latitude) using distance weighting from each station, moisture advection/diffusion, proximity to a coast, elevation, and orographic effect. The 30-year average estimate based on the assumptions used in the PRISM model was compared to actual values for Snotel Chemult Alternate site 395. The difference is $133 \mathrm{~mm}$ more precipitation at Round Meadow. Therefore, the precipitation input was assumed to be $600 \mathrm{~mm}$ at Round Meadow in WY2014. To test the sensitivity of the water budget to difference in the 30 year averages, the change in storage was also calculated using values within $10 \%$ of $133 \mathrm{~mm}$ difference. 
The watershed containing Round Meadow was defined by the point at which Sellers Creek crosses FS 9405. The area of this catchment is $8,572,262 \mathrm{~m}^{2}$. The precipitation input to Round Meadow assuming $600 \mathrm{~mm}$ in WY2014 was calculated at $5,143,357 \mathrm{~m}^{3}$. The calculated values assuming a lower value of $587 \mathrm{~mm}$ precipitation was $5,034,145 \mathrm{~m}^{3}$ and for the higher value of $613 \mathrm{~mm}$ was $5,252,570 \mathrm{~m}^{3}$.

\subsubsection{Spring Discharge}

\section{Groundwater In}

Consistent differences in water temperature, electrical conductivity (Figure 21 and 22), and isotopic composition (see below) between the pine tree, cabin, and outlet springs and the fen and piezometers supported the conclusion that the three springs represent a separate and distinct source of water. Therefore, the combined discharge from the three springs is treated as the $\mathrm{GW}_{\text {in }}$ term in the water budget equation. The measured discharge for the three springs is summarized in Table 7. Discharge for pine tree and cabin springs remained consistent through the season, while the outlet springs fluctuated more broadly (Figure 31). The greatest uncertainty in spring discharge was for the outlet spring because direct measurement in the outflow channel was not possible. Instead, discharge in Sellers Creek above and below the confluence with the outflow channel was measured and the discharge from the springs was taken as the difference in these values as presented in Figure 27. 


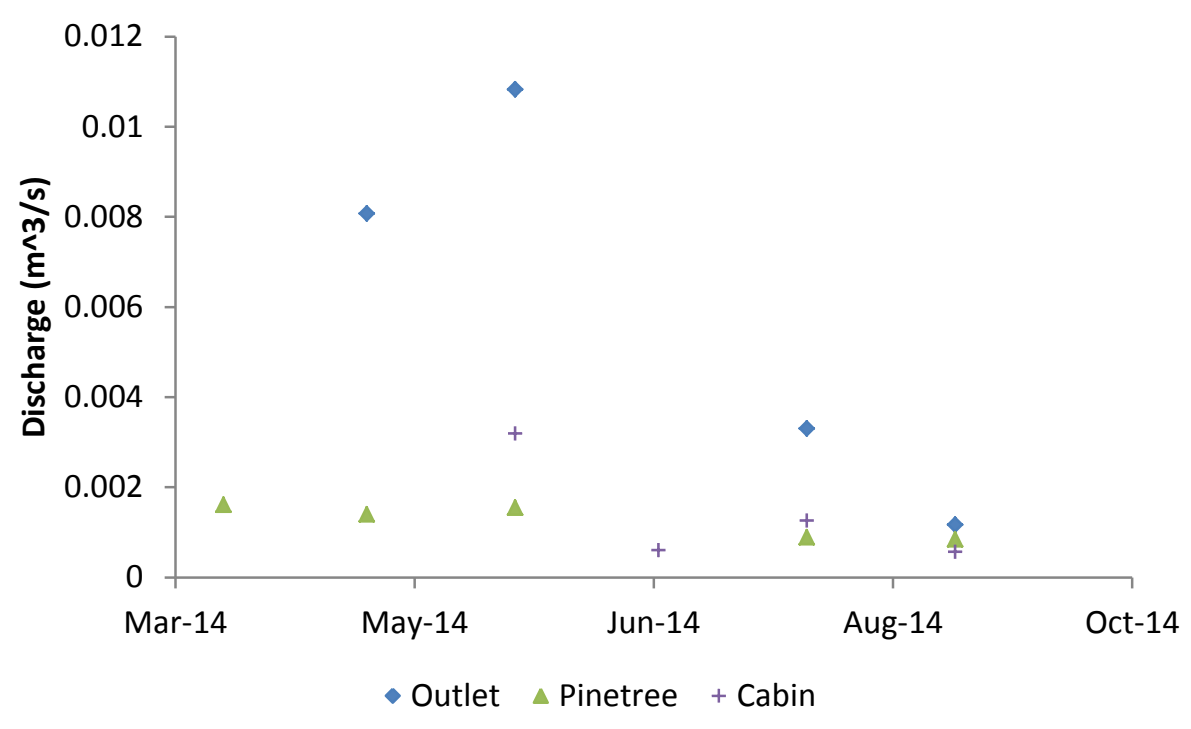

Figure 31: Discharge for 3 springs in Round Meadow. The outlet spring shows the highest variability, but at least some of this effect is inferred to come from the difficulty of gaging this spring relative to the other 2.

The discharge from pine tree and cabin springs flows into the meadow component of the Round Meadow system while the discharge from the outlet spring flows into the outlet component of the system. The average measured discharges for the three springs and the culvert used in the water budget calculation are presented in Table 7. Since the discharge measured at the culvert under FSCR 9405 was selected as $Q$ for the Round Meadow system the discharge from the three springs is combined as $\mathrm{GW}_{\text {in }}=263,500 \mathrm{~m}^{3}$ 
Table 7: Discharge for 3 springs flowing into Round Meadow, and output measured at the intersection of Sellers Creek and FSAR 9405.

\begin{tabular}{lcccc}
\hline Discharge & $\begin{array}{c}\text { Pinetree } \\
\text { (input) }\end{array}$ & $\begin{array}{c}\text { Cabin } \\
\text { (input) }\end{array}$ & $\begin{array}{c}\text { Outlet } \\
\text { (input) }\end{array}$ & $\begin{array}{c}\text { Sellers Creek } \\
\text { (outflow) }\end{array}$ \\
\hline $\mathrm{m}^{3} / \mathrm{s}$ & 0.001 & 0.001 & 0.006 & .008 \\
$\mathrm{~m}^{3} /$ day & 96 & 121 & 505 & 712 \\
$\mathrm{~m}^{3} /$ year & 35,000 & 44,300 & 184,200 & 374,100 \\
\hline
\end{tabular}

\subsubsection{Surface Flow (Q)}

The value for $Q$ was determined by gaging the culvert at FSCR 9405 . The greatest discharge was measure on 19-April-2014 at $0.023 \mathrm{~m}^{3} / \mathrm{s}$. The peak discharge had occurred sometime prior to this date and was not captured because access to the site was not possible. The inferences for changes in discharge were based on the temperature, precipitation, and snow depth data from the Chemult SNOTEL site shown in Figure 32. Based on these data the peak discharge likely occurred between 7February-2014 and 1-March-2014 when the snow water equivalent decreased rapidly. The hydrograph for the culvert between 20-October-2013 and 19-April-2014 was estimated from the following assumptions. Flow through the culvert is assumed to be constant through the winter months and to have a value similar to the discharge in late October. Between 20-October-2013 and February 2014 the discharge was assumed to be $.0042 \mathrm{~m}^{3} / \mathrm{s}$. As temperatures warmed and water was released from the snowpack the discharge would increase to a peak value. This was estimated at $0.05 \mathrm{~m}^{3} / \mathrm{s}$. From the peak, the discharge decreased to the value measured on 19-April-2014. At that time, 
isolated patches of snow were present in heavily shaded areas. Figure 30 indicates that precipitation falling as rain occurred on a few days after 19-April-2014 and was measured as a few mm at the SNOTEL site and between 19-April-2014 and 26-May-2014 at the weather station in Round Meadow. The value assigned to $Q$ for WY2014 was $374,074 \mathrm{~m}^{3}$.

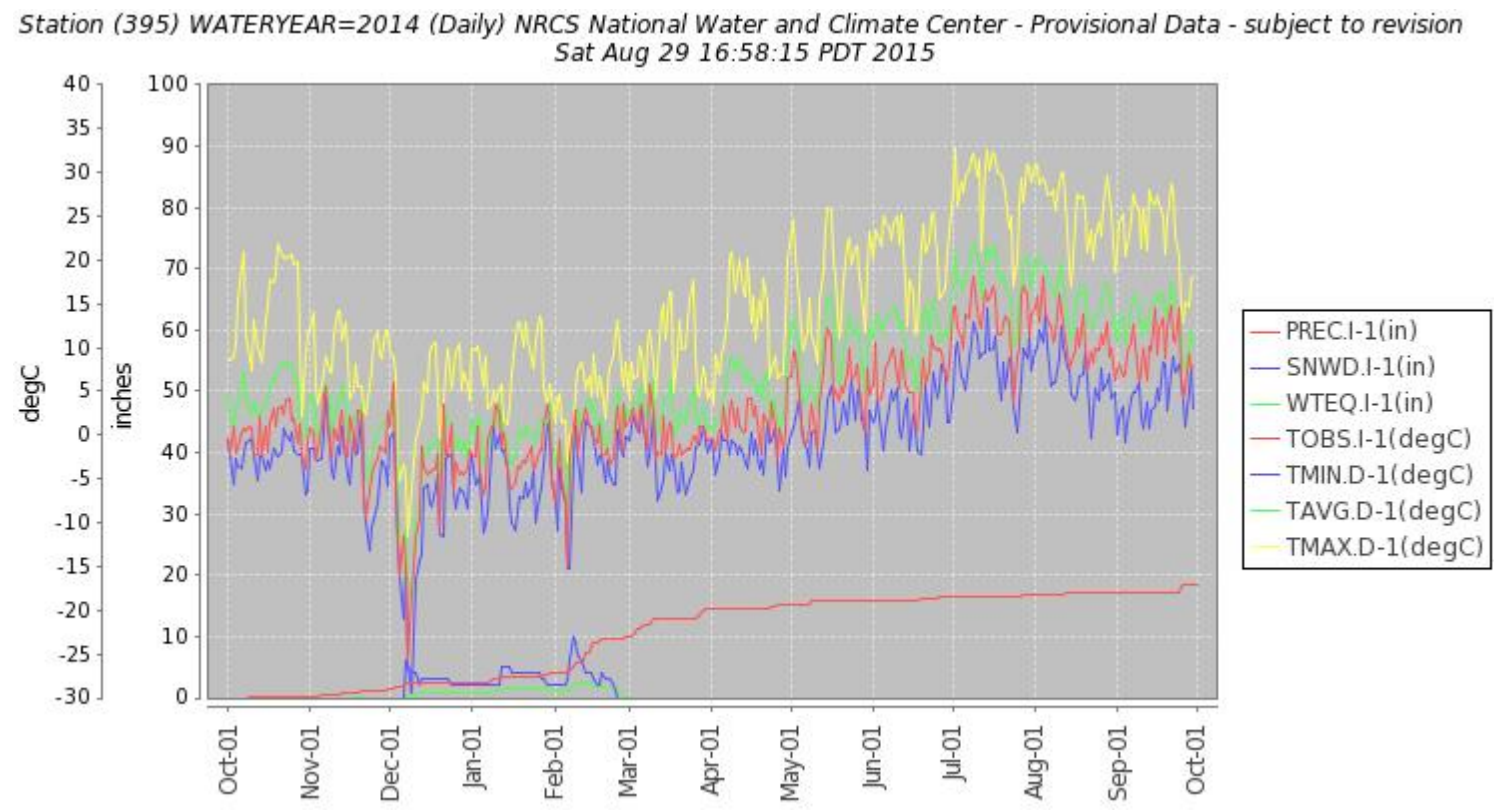

Figure 32 Plot of precipitation, temperature, and snow depth for the Chemult SNOTEL site in WY 2014. The peak discharge at the culvert was inferred to be during the period from early February to 1-March2014 when the snow depth dropped from 10 inches to 0 and did not re-accumulate.

Figure 33 presents the discharge measured at the FSCR 9405 culvert, pine tree, cabin, and outlet springs during WY2014. The discharge at FSCR 9405 is the combined discharge from the meadow and outlet spring. The decrease in discharge at FSCR 9405 culvert is consistent with decrease discharge from the meadow as water levels in the meadow dropped below the elevation of the knickpoint. As summer progressed the 
discharge measured at the culvert became dominated by the discharge from the outlet spring. This relation is further supported by isotopic data presented below.

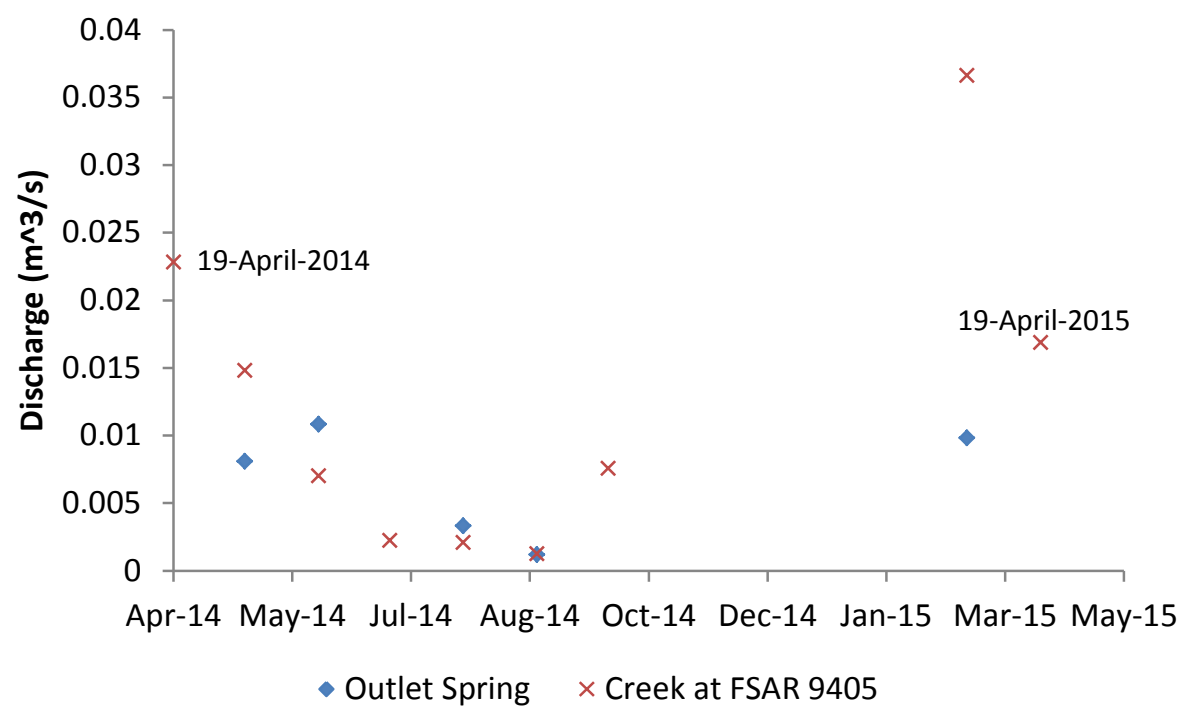

Figure 33: Discharge and flow rates for the outlet spring and Sellers Creek. Note that although WY 2015 was above average precipitation, flow in the creek was actually higher on same day (19-April) measurements in the drought WY 2014, demonstrating an effect of the rain-dominated conditions in WY 2015.

\subsubsection{Evapotranspiration}

Evapotranspiration at Round Meadow was calculated using the modified Penman method detailed in the Methods section and presented in Figure 34. Due to disabling of the pyranometer, the evapotranspiration values between 27-May to 12-July were extrapolated from trends preceding and following these dates as described in the Methods section. An important underlying assumption of this water balance is that evapotranspiration through the winter is minimal in comparison to the summer months.

This assumption is supported by Agrimet data for evapotranspiration for 3 sites near Walker Rim (http://www.usbr.gov/pn/agrimet/monthlyet.html, accessed May, 2015). 


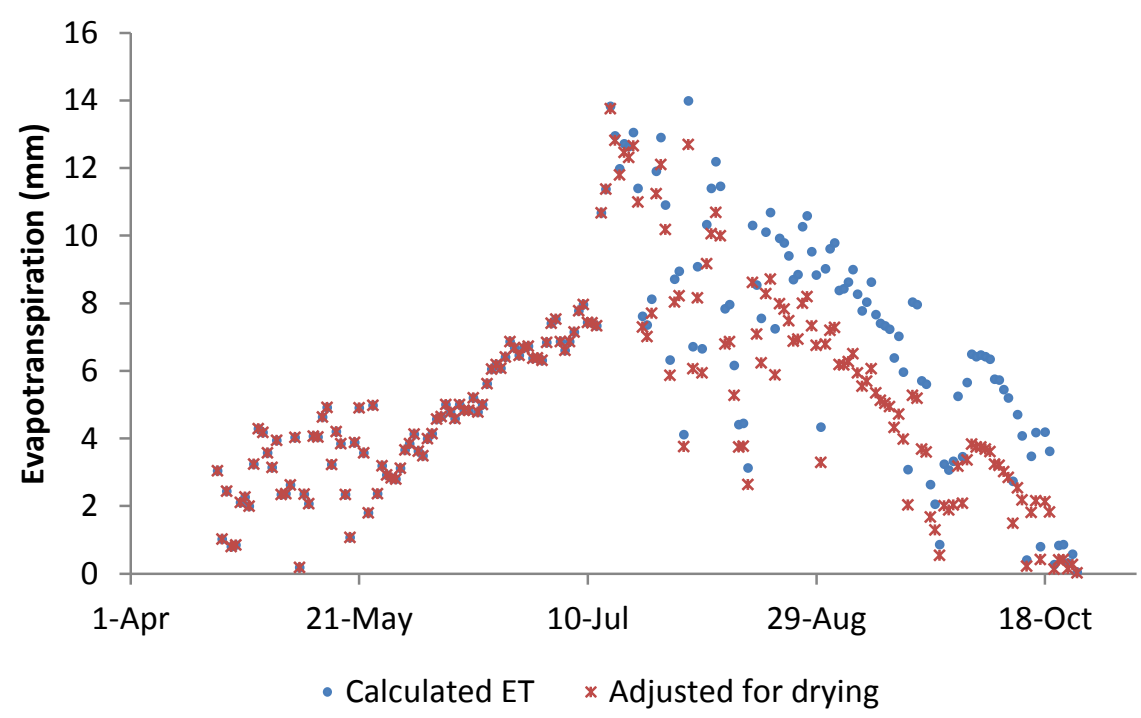

Figure 34: Daily evapotranspiration at Round Meadow calculated by the Penman method for a wellwatered surface, and shown with dampening of effective evapotranspiration for a drying surface.

The output due to evapotranspiration, $E$, for the Round Meadow system was $8,812,300 \mathrm{~m}^{3}$. This value assumes a well-watered surface throughout the growing season. These conditions were most nearly achieved throughout the growing season in the main meadow. Depth to water table measured at 12 tree-watering stakes installed on 19-April-2014 and 20-April-2014 in the main meadow and the vibracore piezometer indicate the water table was within $20 \mathrm{~cm}$ of the ground surface. Later in the season the water table dropped to $50 \mathrm{~cm}$ of the ground surface and water was present at the surface only in the central canal. A study comparing evapotranspiration from an irrigated and a non-irrigated field in the Wood River valley, Oregon found that by midsummer evapotranspiration at the drier field began to diminish until it was $40 \%$ lower 
than the well-watered surface by the end of the water year (Cuenca et al., 2005).

Another study on evapotranspiration rates at wetlands in Indiana with standing water at the surface compared to wetlands with lower water tables found that the Penman method approximated evapotranspiration well in both cases, but predicted that it might deviate with water tables below $30 \mathrm{~cm}$ (Souch et al., 1998). The effects of a drying surface were calculated using the process described in the Methods section.

Calculated average evapotranspiration at Round Meadow was compared to the three nearest Agrimet stations at Agency Lake, Christmas Valley and Beatty, Oregon (Table 8). The results are similar, but Round Meadow is higher in elevation than the other stations, and it shows greater seasonal variability, with lower rates during the cooler months, higher rates in the summer and slightly less evapotranspiration overall.

Table 8: Calculated evapotranspiration at Round Meadow and measured evapotranspiration at 3 nearby Agrimet locations

\begin{tabular}{lcccc}
\hline & Round Meadow & Agency Lake & Christmas Valley & Beatty \\
\hline \hline Daily Average ET (mm) & 5.9 & & & \\
Water Year 2014 (mm) & 1028.9 & 1086.1 & 1067.1 & 1104.6 \\
Adjusted for drying & 917.2 & & & \\
& & & & \\
April (partial) & 2.38 & 3.58 & 3.42 & 3.48 \\
May & 3.19 & 5.48 & 5.11 & 5.17 \\
June & 5.31 & 6.69 & 6.26 & 6.60 \\
July & 9.18 & 7.64 & 7.76 & 7.87 \\
August & 8.64 & 6.28 & 6.48 & 6.71 \\
September & 6.33 & 4.19 & 4.30 & 4.43 \\
October & 3.64 & 2.31 & 2.21 & 2.55 \\
\hline
\end{tabular}




\subsubsection{Groundwater Flow}

\section{Potentiometric Mapping}

The final element of the water budget is groundwater flow out of Round Meadow basin, and this is typically the most difficult flux to quantify. The piezometer network in the meadow coupled with surveyed elevations for each piezometer and spring were used to create potentiometric maps of hydraulic head in the subsurface relative a common datum (Figure 35). The contour maps are from April, August, and October, with little change in the overall trend of decreasing head from west to east. The main effect of evaporation was a drying of the southern end of the meadow as the summer progressed. 

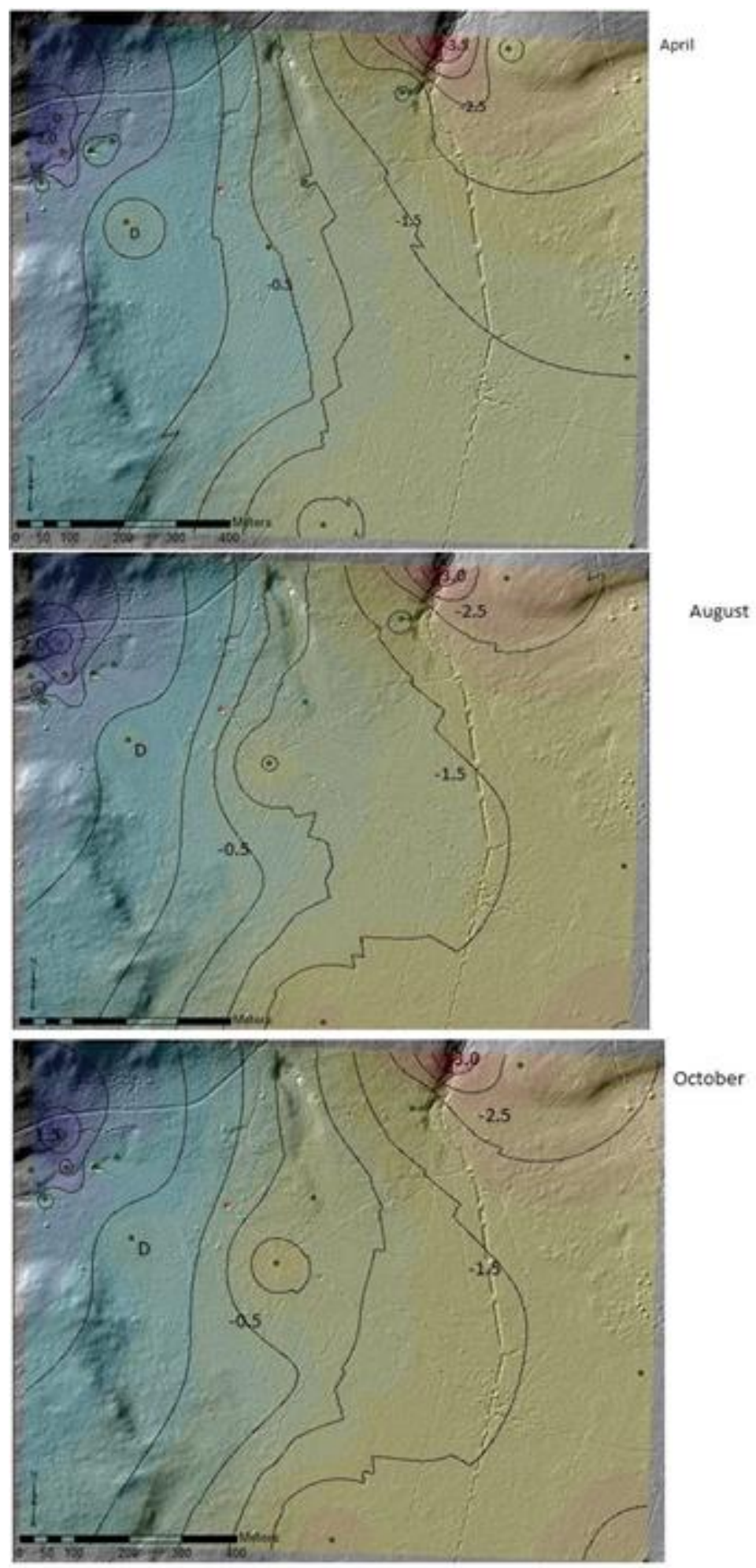

Figure 35: Potentiometic maps of groundwater head surveyed to common datum (labelled 0). Contour interval is $0.5 \mathrm{~m}$. Water table drops with ground level from west to east and much more gradually south to north through the summer. The datum survey point is marked 0 on the maps above 
The value for groundwater leaving the system, $\mathrm{GW}_{\text {out, }}$ is assumed to be negligible based on the hydraulic conductivity of the diatomaceous silt that underlies the meadow and the shape of the potentiometric surface (Figure 35). The estimate of hydraulic conductivity based on the Hazen method was $1.8^{*} 10^{-6} \mathrm{~cm} / \mathrm{s}$, indicating low vertical permeability beneath the meadow. The outflow area is lower in elevation than the base of the pumice aquifer. This is interpreted to mean that the geometry of the aquifer in the meadow is such that groundwater moving laterally in the pumice will join the surface flow in the gaining reach of Sellers Creek before it leaves the basin. The value of $\mathrm{GW}_{\text {out }}$ was therefore set as zero.

\subsubsection{Change in Storage}

The final budget for WY 2014 in the Round Meadow basin was calculated from the equation:

$$
P+G W_{\text {in }}-\left(E T+Q+G W_{\text {out }}\right)=\Delta S
$$

The values used in this calculation (all in $\mathrm{m}^{3}$ of water) were given in the previous section along with the calculations and underlying assumptions for each parameter. The water budget for WY2014 indicates a decrease in storage that is consistent with the drought conditions experienced in the basin. The change in storage in WY2014 is given with minimum, calculated and maximum water flux based on the estimation of error described in the methods section:

$$
\text { Minimum: } 5252500 m^{3}+286800 m^{3}-\left(5992300 m^{3}+347800 m^{3}+\sim 0\right)=-\mathbf{1 2 1 9 2 0 0 m ^ { 3 }}
$$


Calculated: $5143300 m^{3}+268100 m^{3}-\left(8812300 m^{3}+374000 m^{3}+\sim 0\right)=-\mathbf{3 7 7 4 8 0 0} \boldsymbol{m}^{3}$

Maximum: $5034100 m^{3}+249300 m^{3}-\left(11632200 m^{3}+400200 m^{3}+\sim 0\right)=-6330300 m^{3}$

The change in storage was between 14 to $73 \mathrm{~cm}$ of water depth lost over the area of the basin. The calculated change in storage is equal to $44 \mathrm{~cm}$ of water depth lost over the area of the basin. Note that the minima and maxima are switched - lowest water flux is calculated from greatest precipitation paired with least evapotranspiration and vice versa.

\subsection{Water Age Dating}

Groundwater samples were collected from 2 sites, the vibracore piezometer and the upper orifice of the outlet spring. These were analyzed to estimate a recharge age of most recent exposure to the atmosphere based on concentration of CFC-11, CFC-12,

CFC-113, and SF-6. The age dates are presented in Table 9. Uncertainty for each of the ages for all markers was \pm 2 years.

Table 9: Time elaspsed in years since water was exposed to atmosphere for 4 different trace chemicals

\begin{tabular}{ccccc}
\hline Location \& Sample \# & CFC-12 & CFC-11 & CFC-113 & SF $_{6}$ \\
\hline \hline Outlet Spring 1 & $\mathbf{2 7}$ & 34 & 25 & 11 \\
Outlet Spring 2 & $\mathbf{2 7}$ & 34 & 27 & 13 \\
Outlet Spring 3 & $\mathbf{2 7}$ & 34 & 27 & 8 \\
Vibracore 1 & $\mathbf{3 4}$ & 42 & 31 & 6 \\
Vibracore 2 & $\mathbf{3 7}$ & 51 & 34 & 0 \\
Vibracore 3 & $\mathbf{3 8}$ & 50 & 34 & 10 \\
\hline
\end{tabular}


CFC-12 concentration was deemed to be the best indicator for recharge age of the water for several reasons. First, CFC-11 and CFC-113 concentrations in the atmosphere stopped rising and began to decline in 1994, which creates a possibility of 2 different recharge ages at the same concentration on either side of this inflection point (Bullister et al., 2002). CFC-12 concentration in the atmosphere continued to increase slowly until 2003, an inflection point which is outside the range of derived ages for the Round Meadow waters. Secondly, CFC-11 concentration has been found to decrease in anoxic or sub-oxic conditions, which would return an artificially older apparent age for the water than from the other 3 markers (Happell et al., 2003). This may account for the older recharge ages derived from CFC-11 concentration for the vibracore samples shown above.

$\mathrm{SF}_{6}$ has recently been thought to be a more reliable indicator in many environments for age dating since it is accumulating rather than declining in the atmosphere like the 3 CFC markers. However, trace amounts of terrigenic $\mathrm{SF}_{6}$ have been found to occur in aquifers formed in basalt and in fractured silicic igneous rocks, rendering this marker less useful in volcanic terrains (Busenberg and Plummer, 2000; Koh et al., 2007). The presence of naturally occurring $\mathrm{SF}_{6}$ would skew the age date younger, and this may explain the inconsistent derived ages shown above.

This leaves an average age for the spring water of 27 years and an average age for the water in the pumice aquifer of 37 years. Recent studies have shown that water ages based on CFC concentration and other tracers are commonly inaccurate where 
dispersion or mixing of differently aged water skews the concentration (Weismann et al., 2002). The presence of very old, or (more commonly) very young water may produce a result in which the calculated average age does not represent the actual age of any of the water. The characteristics of pumice, $80 \%$ to $90 \%$ interconnected vesicles joined by narrow pore throats (Klug et al., 2002) suggests water of different ages may be in the pumice aquifer. Older water is likely present in the pumice grains. However, displacement of this older water by the younger water between grains is likely a slow process. It is not known how closely the water samples from the pumice aquifer matches well-mixed water. Likewise, the aquifer from which the spring discharges is not known. Therefore, the absolute ages produced by the CFC analysis may be meaningless. However, the relative ages of the waters and the approximate range of ages are still considered valid and will be used in assessing the hydrologic system at Round Meadow. 


\section{Chapter 4: Discussion}

The data from the water budget, isotope analysis, and water age dating reveal multiple hydrologic systems that while they are united by proximity, function independently. Observations during the drought of WY2014 allowed discrete sources, storage, and fluxes of water to be identified within the Round Meadow basin. The discussion will first examine the evolution of the Round Meadow basin from the blanketing by the pumice deposit to the stratigraphy of the modern meadow, focusing on processes that have disrupted the original lateral continuity of the Plinian pumice fall. The second section will discuss each of the 4 hydrologic components in the basin; the ways in which they are isolated and how they interact to form the hydrogeology of Round Meadow. The third topic of discussion relates to water resource management. The discrete hydrogeologic systems present in Round Meadow suggest that the independent functioning of these components is an important factor when considering management practices in this basin.

\subsection{Evolution of post-eruption Round Meadow}

At the end of the cataclysmic eruption of Mount Mazama, the Round Meadow area would have been covered by approximately three meters of pumice characterized by lateral continuity of physical properties. The differences in physical properties are expressed in vertical stratification caused by changes in the eruption (Klug et al., 2002). These include grain size differences between the lower and upper pumice units, the relative abundance of crystal and lithic clasts, and the degree of sorting. The 
hydrogeologic evolution of Round Meadow basin has resulted in disruptions to the lateral continuity of the Plinian pumice fall.

The history of these disruptions is reflected in the stratigraphy of the modern meadow. Following the eruption the full pumice section would have overlain the relatively far less permeable pre-eruption diatomaceous silt (Table 4). The knickpoint area where the meadow drains to Sellers Creek was dammed during this time. It is interpreted that the pre-eruption landscape would still have focused water to the knickpoint area and this dam may have failed with some energy, evidenced by the $50 \mathrm{~cm}$ terrace to the west of the inundated area that is the headwater for Sellers Creek. With enough cumulative precipitation the meadow would have filled to a level where it drained freely over the knickpoint, as it does in modern times (Figure 25). The poorly sorted upper pumice ( $1 \mathrm{~cm}-7 \mathrm{~cm}$ blocks) would have floated under these conditions. It has been shown that pumice can float for over a year, and the length of time needed to saturate blocks increases with size (Witham and Sparks, 1986; Manville et al., 1998).

When the upper pumice was removed by floating over the knickpoint, it created accommodation space in the meadow for sediment being transported from the higher parts of the basin. It is inferred that much of this new material would also have been floated and removed in the early evolution of the basin. The layer that is commonly at the contact with the Plinian pumice fall is $10-15 \mathrm{~cm}$ of well-sorted lithic- and crystal-rich lag sand. This represents the denser part of the pumice deposit that sank when the larger pumice floated. Overlying the lag sand is subangular pumice and it is inferred that 
weathering and transport would have opened the vesicles within the pumice making it more permeable and less buoyant. Above the subangular pumice are the diatomaceous silt layers that are a product of more recent erosion and deposition in the basin. Those processes formed the fans that are visible in the northwest, southwest, and eastern edges of the meadow. Flow from channels at the margins of the meadow has cut an erosional surface into the top of the Plinian fall pumice deposit. Onto that surface are deposited alluvial silt wedges that thin and pinch out as they approach the central meadow (Figure 6). Sediment in the central meadow is thickened organic silt. Iron cementation and staining has been found at the contact between both the alluvial and organic silt and the Plinian pumice fall. This may be another factor contributing to the isolation of the water near the surface and the water in the pumice aquifer.

Sedimentation at the margins of the modern meadow are dominated by alluvial erosion and deposition while the central meadow is dominated by paludal or lacustrine floatation and burial processes.

\subsection{Hydrogeologic components of the Round Meadow basin}

The drought conditions starting in WY2013 and reaching a climax in WY2014 allowed the identification of the independently functioning hydrogeologic components of the Round Meadow system. The rain-dominated winter precipitation pattern of WY2015 increased the definition of these hydrogeologic components. The order of discussion follows the importance of each component in the water budget. 


\subsubsection{The Central Meadow}

In WY2014, 95\% of the water entering the basin was from precipitation and $79 \%$ of that fell from October to April. In the same year, $98 \%$ of the water that left the basin was due to evapotranspiration from April through September. Storage in the meadow is the key component for tracking water fluxes in this basin. While the fen, springs, and outflow area are important for a more complete understanding of the hydrogeology, the water transferred in the meadow dwarfs them by volume.

The elevation data for water in the piezometers compared to water at the surface (Table 3) indicates that in WY 2014 water in the canals near the ground surface was disconnected from the water table in the pumice aquifer. This conclusion is supported by the following data: 1) The water levels in the nested piezometers and some auger holes indicate that there is positive head within the pumice aquifer where post-eruption diatomaceous silt is penetrated, indicating that the post-eruption diatomaceous silt is a low-permeability barrier to flow. 2) The groundwater velocity calculations (Table 4) indicate that travel time for precipitation falling on the meadow to move through the post-eruption diatomaceous silt to the aquifer below would be on the order of hundreds of days - a much longer time scale than either evaporative flux at the surface or seasonal precipitation which would raise water levels in the meadow above the knickpoint. 3) The isotopic analysis for the water in the main canal and the vibracore piezometer, both sampled on 26-October-2014 indicated that the canal water was highly evaporative in character (Figure 29), yet apparently none of this signal was mixed 
with the water at the vibracore about 25 m away. 4) The water in Sellers Creek on 17May-2015 was also evaporative (although much less so), indicating that early in the season most of the flow from the meadow is surface water.

The disconnection of surface and ground water probably occurs on a continuum during most water years. The water table remains closest to the surface near the main canal, the topographically lowest part of the meadow. In wet years the water in the pumice aquifer may remain in contact with the canals through the summer and maintain that connection over a greater area. In dry years like WY 2014 the piezometers and isotope ratios near the canal indicate that the waters may have completely separated.

A conceptual model of the meadow is developed in which precipitation falling in the basin on the relatively high-permeability pumice section above 1710 m elevation moves primarily laterally within the pumice to recharge the aquifer in the meadow (Figure 36). This model of recharge is a consequence of the observation that the surface water does not substantially reach the Plinian pumice fall: the aquifer is recharged, but not by surface flow. This is supported by 1 ) the seasonal stream that was found flowing into the basin on 7-March-2015 but disappeared into the pumice before reaching the central meadow. 2) Piezometers outside the central meadow - the $90 \mathrm{~m}$ (Figure 16) and the south fence piezometer (Appendix A) had elevated water levels in March 2015, but these have gone dry each summer since being installed. 
Precipitation that falls within the meadow at elevations below 1710 m remains near the ground surface and either flows over the knickpoint or is removed through evapotranspiration. Discharge from the pine tree and cabin springs dissipates on the surface of the meadow, and piezometer data discussed above indicates that the channels are disconnected from the pumice aquifer. This model suggests that the surface water is mostly replaced seasonally, while water in the pumice aquifer has a longer residence time (decades) and is not well-mixed with surface water. The CFC water age dates indicate that the water in the pumice (Table 9) may only be replaced through longer cycles of wet and dry years. Visual observations over 4 summers at Round Meadow were that by fall surface water is mainly present in the canals with ponding in the east central meadow during wet years. 


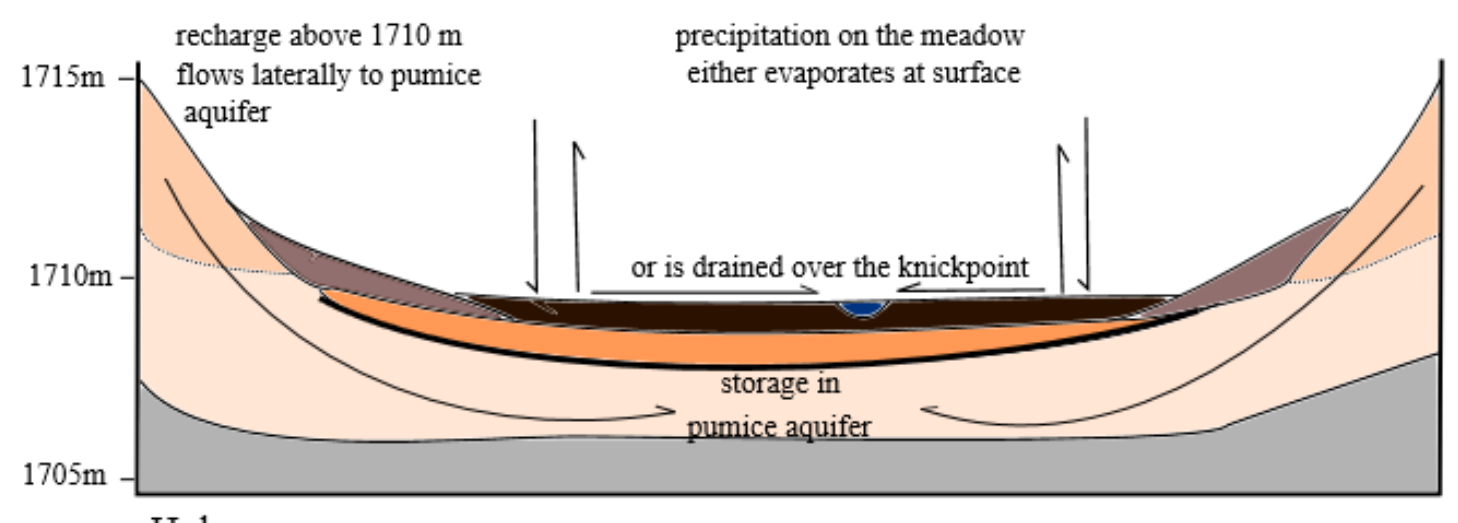

Holocene

Diatom-bearing dark brown silt to organic-rich silt

Silt bearing sub-rounded pumice granules to pebbles

Lithic- and crystal-rich sand, minor pumice
Upper unit Plinian pumice fall

Lower unit Plinian pumice fall

Diatomaceous silt

Figure 36: A conceptual model of recharge of storage in the pumice aquifer. Precipitation that falls on the upper pumice unit present above $\mathbf{1 7 1 5} \mathrm{m}$ elevation soaks into this relatively high permeability layer and recharges the aquifer laterally through the lower pumice. Precipitation that falls on the low permeability silt is either drained through the main canal during the freshet or evaporates at the surface of the meadow. For clarity, this figure omits the contribution from spring discharge at the northern margin of the meadow, which contributes only about $5 \%$ of the water input (Table 7).

The recharge of the pumice aquifer may also be dependent not just on the quantity of water falling in the basin but on the type of precipitation. A growing body of evidence suggests that an increased share of the precipitation falling as rain will recharge watersheds less deeply than snow-dominated precipitation. Recent studies in Oregon have compared the effect of shifting climate on the younger volcanic High Cascades to the older Western Cascades. In the High Cascades drainage is mainly through relatively high permeability sediment and jointed volcanic rocks to groundwater 
storage, and this is similar to conditions at Walker Rim including Round Meadow. The Western Cascades have older soils and better-established stream networks and drainage is mainly surface flow (Tague and Grant, 2004). Models suggest that groundwater dependent systems are more susceptible to loss of more of their longterm hydraulic storage in rain-dominated climates (Tague et al., 2007).

Although WY 2015 received more precipitation than the 30 year average, most of the precipitation came as rain, and the base storage in the meadow does not appear to have been restored to pre-2014 levels. Water levels in southeast, southwest, and cabin piezometers were lower in WY 2015 than they were on same day measurements in WY 2014, as was flow in Sellers Creek.

\subsubsection{The Fen}

Water year 2014 provided an opportunity to observe the Round Meadow hydrologic system under stress. The basin lost nearly half a meter of water from storage, and the impact at the fen was particularly notable. Previous work concluded that the fens at Johnson, Wilshire and Dry meadows are recharged by deep springs (Aldous and Gurrieri, 2011). More recent work suggested that the fens are supported by seasonal water being concentrated near the surface by pre-eruption topography (Cummings et al., 2014). Water levels in the fen at Round Meadow stayed within $10 \mathrm{~cm}$ of the local ground surface through the summer during WY2011 and WY2012, possibly indicting a deeper groundwater recharge source. However, during the drought year of 2014, the fen dried to nearly $1 \mathrm{~m}$ below local ground surface suggesting that water levels in the 
fen are sensitive to inter-annual variation in precipitation. The sedges, rushes, and bryophytes that thrived on the fen in WY2011-WY2013 were stressed and the ground in the fen area was hardened rather than soft and springy as in wetter years

Despite the drying at the fan, nearby pine tree spring continued to flow steadily, indicating that the spring was recharged by a different source than the fen. Based on the observations of the system under stressed conditions it was concluded that the fen at Round Meadow is wholly or mostly dependent on seasonal recharge, not a distant or deep-seated source. March and April WY2015 water levels in the fen indicated recovery of head levels in the pumice aquifer relative to the end of WY2014, however, the raindominated winter precipitation pattern of WY2015 did not fully recharge the system. Water in the mystery hole at the fen was lower in March and April 2015 than it was in July 2011, 2012, and 2013.

\subsubsection{The Springs}

The water discharged at the 3 known springs at Round Meadow is different from the groundwater in the pumice aquifer based on temperature, conductivity, water age, and isotopic ratios. The fact that all 3 springs had relatively undiminished flow despite the drought of WY 2014 indicates that they are sourced in a system that does not respond noticeably to seasonal variability. The persistent low temperatures suggest that the water is moving for longer periods at depths of $10 \mathrm{~m}$ or greater. However, the low electrical conductivity (32.4 to $48.4 \mu \mathrm{S} / \mathrm{cm}$ ) suggest these waters do not circulate to great depth or for long periods of time. 
The age of the water, lack of response to seasonal variation and the implied depth of the system suggest that the springs are recharged outside of the Round Meadow basin. This effect was found to be common in basins with frequent Quaternary volcanism (Jefferson et al., 2006). The lighter isotopic signature suggests a higher recharge elevation (Poage and Chamberlain, 2001). The proximity of Walker Rim, about $300 \mathrm{~m}$ higher and $6 \mathrm{~km}$ to the west offers a source which fits these data, but no evidence is known to directly link the areas.

\subsubsection{Outflow}

Water levels in the confluence and outlet piezometers showed the least variability from year to year compared to the meadow and the fen. In the area of Sellers Creek much of the Plinian pumice fall and the fine-grained sediments that overlie it in the meadow have been eroded. It is inferred that the outflow area does not have the storage or water holding capacity of the meadow and fen, so water levels drop even in wet years. However it also seems to receive hydraulic input from Sellers Creek, so these piezometers have never gone dry, even in drought years.

The geomorphic features in the outlet component indicate a complex geomorphic history. The key geomorphic features are the gently south sloping surface along the northern margin of Round Meadow that mimics the dip on the welded tuff, the intermittent stream valley that enters the confluence area from the east, and the subtle change in slope and direction of Sellers Creek from areas where it flows across the welded tuff to areas where it flows across materials that underlie the welded zone 
of the tuff. The south sloping surface formed by processes active shortly after the eruption as rill networks developed with flow direction to the south toward the meadow. At this time, the confluence area and knickpoint were buried beneath approximately $3 \mathrm{~m}$ of pumice blocking the outlet to Sellers Creek. The intermittent stream valley entering from the east partially removed this blockage. Apparently during this time, a lake was ponded within the meadow south of the confluence. Eventually the level in this lake exceeded the elevation of the blockage that was also being lowered by erosion associated with the intermittent stream. Once the barrier was breached the fan built at the mouth of the intermittent stream was cut through and the pumice deposit in the upper reaches of Sellers Creek was eroded and deposition occurred locally to establish the current configuration of Sellers Creek. The gaining reach of Sellers Creek corresponds to the area underlain by the welded zone of the tuff. The losing reach is where the creek flows across the stratigraphic units that underlie the welded zone.

The outflow area may represent a longer developed version of the evolution of channel networks after the $1980 \mathrm{Mt}$ St Helens eruption. Studies there found that the ground surface following the eruption was "armored", so initially surface flow dominated. In less than a year rill networks began to establish and when this occurred it was followed by rapid channel incision through unconsolidated volcaniclastic sediment. This persisted for 3 to 5 years until streams down cut to more resistant layers and more typical streamflow conditions began to be re-established, leaving many deeply incised 
channels with low or intermittent flow (Collins and Dunne, 1986; Major and Mark, 2006).

\subsection{Management Implications}

Inter-annual variation in the amount of precipitation and the dominant type of winter precipitation have implications for water resource management at Round Meadow. The water resources of the Round Meadow basin are dominated by the storage in the pumice aquifer and reworked pumice-rich deposits that underlie the posteruption diatomaceous silt. However, much of this storage is at elevations below the knickpoint at the head of Sellers Creek. The volume of the storage is primarily below $1710 \mathrm{~m}$. The volume of storage is greater in the spring as water moves toward the meadow from the surrounding uplands. Although some of this water moves as surface water such as was observed on 7-March-2015 in the southeast corner of the meadow, most likely moves in the subsurface within the pumice deposit. Groundwater below an elevation of $1710 \mathrm{~m}$ is characterized by residence times measured in decades. Minor recharge of the pumice aquifer during the summer takes place by discharge from pine tree and cabin springs. However, this is a small volume (Table 7).

The area of Round Meadow below $1710 \mathrm{~m}$ is likely the part of the hydrogeologic system most sensitive to management practices. This part of the meadow is underlain by organic-rich silt and post-eruption diatomaceous silt. The latter of these units forms the upper confining layer for the pumice aquifer. Here, the volume of water and the inundated area of the meadow depends on the amount of precipitation. It apparently 
does not matter whether precipitation falls as snow or rain during the winter season. The volume of water stored in this part of the system is ultimately controlled by the elevation of the knickpoint. Once the elevation of the knickpoint has been reached the water level fluctuates around a set value rising higher during large precipitation events or during rapid snow melt and falling during dry periods. Raising the elevation of the outlet could increase storage in the meadow, however, this would be limited to the area underlain by the post-eruption diatomaceous silt. Beyond the areal limits of the posteruption diatomaceous silt, surface water would infiltrate into space occupied by the pumice aquifer. The largest discharge from the Round Meadow system occurs from this part of the system due to evapotranspiration. The shift in isotopic composition of water from canals and the spring discharge in Sellers Creek confirmed this relation.

The three springs considered in this study are a separate and distinct hydrogeologic system. As indicated above, pine tree and cabin springs provide a minor contribution to the pumice aquifer where they discharge from canals that have been constructed to carry water away from the springs. At time scales observed in this study, the discharge from these springs is relatively constant and does not appear to fluctuate relative to inter-annual variation in precipitation. The outlet spring is one of what may be several areas of spring discharge to Sellers Creek in the outlet component of the Round Meadow system. The discharge from these springs may vary with season but produces perennial flow in the reach of Sellers Creek considered in this study. The 
springs were the dominant source of flow in Sellers Creek during the dry season when surface discharge from Round Meadow had ceased or was minimal.

The fen and wet meadow in the northwest part of Round Meadow are minor players in the hydrologic system. Although some recharge from groundwater rising through fractures in the welded tuff cannot be ruled out, the discharge through the fen face and the flanking wetlands appears to follow the inter-annual variations in precipitation, but does not appear to respond as effectively when most of the precipitation falls as winter rain. The fen and wet meadow areas need to be managed for the support of the groundwater-dependent ecosystems they contain. The recharge of the fen and flanking wetlands appears to rely on groundwater moving through the unconfined pumice aquifer. 


\section{Chapter 5: Conclusions}

Observation and investigation of the Round Meadow basin during the drought of WY 2014 allowed several insights into the functioning of the hydrologic system. Following the inundation of the basin by up to $3 \mathrm{~m}$ of Plinian pumice fall the system is comprised of four spatially related but independently functioning components. These were the meadow, which is the largest component in area, the fen where iron cementation and up to $1 \mathrm{~m}$ of peat holds water in a berm above the meadow, three springs which are sourced from deeper groundwater moving in the bedrock which underlies the pumice deposit, and the outflow area.

The central meadow is the dominant component for water storage. This is mainly held in the aquifer which is hosted within the lower pumice, lag sand, and reworked pumice layers. The change in storage in WY2014 ranges from $1219200 \mathrm{~m}^{3}$ to $6330300 \mathrm{~m}^{3}$ basin wide, with a calculated change in storage of $3,774,892 \mathrm{~m}^{3}$ or $44 \mathrm{~cm}$ of water depth. Precipitation was the dominant source of water input to the basin and evapotranspiration was by far the greatest sink of water removal. The inherent uncertainty in calculating this parameter was the main cause of the broad range in values for change in storage.

Although the fen at Round Meadow is an area of relatively high biodiversity, it was only a minor component of the water budget in the basin. Contrary to previous interpretation, the fen was not significantly recharged by groundwater. Water levels at the fen dropped up to $95 \mathrm{~cm}$ below local ground surface while discharge at the nearby 
pine tree spring was relatively unchanged. The stressed conditions of WY 2014 indicated that the fen is more sensitive to changes in interannual precipitation than other components in the system.

Water discharging from the 3 springs in Round Meadow was isotopically lighter than the surface and groundwater in the meadow. Temperature of the spring discharge was less responsive to seasonal heating through the summer than the surrounding water and unlike the groundwater did not increase in electrical conductivity through the season. These three factors combined to indicate a deeper source of recharge for the springs than for the ground and surface water. The springs were less responsive to the drought of WY 2014, than other components of the system, indicating that the source of recharge may be larger than the Round Meadow basin.

The rain-dominated winter precipitation in WY2015 was above the 30 year average. This produced an increase in storage compared to the end of WY 2014. However, water levels in April 2015 were lower than they were on the same date following the drought winter of WY2014. 


\section{References}

Aldous, A., and Gurrieri, J., 2011, Environmental Flows and Levels for GroundwaterDependent Fens of the Antelope Grazing Allotment, Fremont-Winema National Forest, Oregon, The Nature Conservancy/United States Forest Service, 93 p.

Bacon, C. R., and Lanphere, M. A., 2004, Eruptive history and geochronology of Mount Mazama and the Crater Lake region, Oregon: Geological Society of America Bulletin, v. 118, p. 1331-1359.

Bouwer, H., Rice, R.C., 1976, A slug test for determining hydraulic conductivity of unconfined aquifers with completely or partially penetrating wells: Water Resources Research, v. 12, p. 423-428.

Bullister, J., Wisegarver, D., Menzia, F., 2002, The solubility of sulfur hexafluoride in water and seawater: Deep Sea Research Part 1: Oceanographic Research Paper, v. 49, p. 175-187.

Cappa, C. D., Hendricks M. B., DePaolo, D. J., Cohen, R. C. , 2003, Isotopic fractionation of water during evaporation: Journal of Geophysical Research, v. 108, p. 13-1-13-10.

Collins, B. D., Dunne, T., Erosion of tephra from the 1980 eruption of Mount St. Helens: GSA Bulletin, v. 97, p. 896-905.

Cummings, M.L., 2007, Groundwater capture of surface drainage during post-eruption landscape evolution, Williamson River basin, Oregon: Hydrological Science and Technology, v. 23, p. 79-90.

Cummings, M. L., Conaway, J. S., 2009, Landscape and hydrologic response in the Williamson River basin following the Holocene eruption of Mount Mazama, Cascade volcanic arc: GSA Field Guides, v. 15, p. 271-294.

Cummings, M. L., Weatherford, J. M., Mowbray, L. A., 2014, Hydrogeology of pumicehosted fens in the Winema-Fremont National Forest, Oregon, USA: Journal of Water Resource and Protection, v. 6, 18 p.

Daly, C., Halbleib, M., Smith, J. I., Gibson, W. P., Doggett, M. K., Taylor, G. H., Curtis, J., Pasteris, P. P., 2008, Physiographically sensitive mapping of climatological temperature 
and precipitation across the conterminous United States: International Journal of Climatology, v. 28, p. 2031-2064.

Devore, J. L., 2012, Probability and Statistics for Engineering and the Sciences: Boston, MA, Brooks-Cole, 698 p.

Dingman, S. L., 2002, Physical Hydrology: Long Grove, IL, Waveland Press, 646 p.

Faure, G., and Mensing, T., 2005, Isotopes Principles and Applications: Hoboken, NJ, John Wiley \& Sons, 897 p.

Fetter, C. W., 2011, Applied Hydrogeology: Upper Saddle River, NJ, Prentice-Hall, 598 p.

Gannett, M. W., Lite, K. E., Morgan, D. S., Collins, C. A., 2001, Ground - water hydrology of the Upper Deschutes Basin, Oregon: United States Geological Survey, WaterResources Investigations Report 00-4162, 77 p.

Harbeck, G. E., 1972, A practical field technique for measuring reservoir evaporation utilizing mass-transfer theory: United States Geological Survey Professional Paper 272-E.

Janssen, K. D., and Cummings, M. L., 2007, Summer (2004) evaporation from Upper Klamath Lake, Klamath County, Oregon: U.S. Fish and Wildlife Service, Klamath Basin Ecosystem Restoration Office, 39 p.

Jefferson, A., Grant, G., Rose, T., 2006, Influence of volcanic history on groundwater patterns on the west slope of the Oregon High Cascades: Water Resources Research, v. 42, W12411.

Koh, D., Plummer, L., Busenberg, E., Kim, Y., 2007, Evidence for terrigenic $\mathrm{SF}_{6}$ in groundwater from basaltic aquifers, Jeju Island, Korea: Implications for groundwater dating: Journal of Hydrology, v. 339, p. 93-104.

Klug, C., Cashman, K. V., Bacon, C. R., 2002, Structure and physical characteristics of pumice from the climactic eruption of Mount Mazama (Crater Lake), Oregon: Bulletin of Volcanology, v. 64, p. 486-501.

Landon, M. K., Rus, D. L., Harvey, E. F., 2005, Comparison of instream methods for measuring hydraulic conductivity in sandy streambeds: Groundwater, v. 39, p. 870-885.

Major, J. J., Mark, L. E., Peak flow responses to landscape disturbances caused by the cataclysmic 1980 eruption of Mount St. Helens, Washington: GSA Bulletin, v. 118, p. 938-958. 
Manville, V., White, J.D.L., Houghton, B.F., Wilson, C.J.N., 1998, The saturation behavior of pumice and some sedimentological implications: Sedimentary Geology, v. 119, p. 516.

McGuire, K., McDonnell, J., Weiler, M., Kendall, C., McGlynn, B., Welker, J., Seibert, J., 2005, The role of topography on catchment-scale water residence time: Water Resources Research, v. 41, W05002.

Moffitt, F. H., Bouchard, H., 1992, Surveying: Harper Collins, Glenview, IL, 848 p.

Palmer, C. P., Gannett, M. W., Hinkle, S. R., 2006, Isotopic characterization of three groundwater recharge sources and inferences for selected aquifers in the upper Klamath Basin of Oregon and California, USA: Journal of Hydrology, v. 336, p. 17-29.

Plummer, L., and Busenberg, E., 2000, Dating young groundwater with sulfur hexafluoride: Natural and anthropogenic sources of sulfur hexafluoride: Water Resources Research, v. 36, p. 3011-3030

Poage, M., and Chamberlain, C., 2001, Empirical relationships between elevation and the stable isotope composition of precipitation and surface water: considerations for studies of paleoelevation change: American Journal of Science, v. 301, p. 1-15.

Schwartz, F. W., Zhang, H., 2003, Fundamentals of Groundwater: New York, NY, John Wiley \& Sons, 583 p.

Tague, C., Grant, G., Farrell, M., Choate, J., Jefferson, A., 2007, Deep groundwater mediates streamflow response to climate warming in the Oregon Cascades: Climate Change, v. 86, p. 189-210.

Vallet-Coulomb, C., Legesse, D., Gasse, F., Travi, Y., Chernet, T., 2001, Lake evaporation estimates in tropical Africa (Lake Ziway, Ethiopia): Journal of Hydrology, v. 245 p. 1-18.

Weissmann, G. S., Zhang, Y., LaBolle, E. M., Fogg, G. E, 2002, Dispersion of groundwater age in an alluvial aquifer system, Water Resources Research, v. 38, p. 16-1-16-13.

Winter, T. C., 1999, Relation of streams, lakes and wetlands to groundwater flow systems: Hydrogeology Journal, v. 7, p. 28-45.

Winter, T. C., Rosenberry, D. O., Sturrock, A. M., 1995, Evaluation of 11 equations for determining evaporation for a small lake in the North Central United States: Water Resources Research, v. 31, p. 983-993. 
Winter, T. C., 1981, Uncertainties in estimating the water balance of lakes: Water Resources Bulletin, v. 17, p. 82-115.

Young, S. R., 1990, Physical volcanology of Holocene airfall deposits from Mt. Mazama, Crater Lake, Oregon: Doctoral Thesis, University of Lancaster. 


\section{Appendix A: Water Level Measurements}

\begin{tabular}{|c|c|c|c|c|c|c|c|c|c|}
\hline \multirow[t]{2}{*}{ UTM E } & \multirow[t]{2}{*}{ UTM N } & \multirow[t]{2}{*}{ Place Name } & \multicolumn{7}{|c|}{ Sampling Date } \\
\hline & & & 19-Apr-14 & 17-May-14 & 21-Apr-14 & 12-Jul-14 & 16-Aug-14 & 19-Sep-14 & 27-Oct-14 \\
\hline 611132 & 4798972 & Fence & dry $(-188)$ & ns & dry(-188) & $\operatorname{dry}(-188)$ & $\operatorname{dry}(-188)$ & $\operatorname{dry}(-188)$ & $\operatorname{dry}(-188)$ \\
\hline 611080 & 4798903 & 30m Piez & -49 & -70 & dry(-86) & $\operatorname{dry}(-86)$ & $\operatorname{dry}(-86)$ & $\operatorname{dry}(-86)$ & $\operatorname{dry}(-86)$ \\
\hline 611095 & 4798877 & 60m Piez & -15 & -37 & -67 & -79 & -114 & -132 & -141 \\
\hline 611105 & 4798852 & 90m Piez & -151 & -171 & -130 & -184 & -182 & $\operatorname{dry}(-189)$ & -186 \\
\hline 611143 & 4798911 & Myst Hole & -10 & 0 & -30 & -52 & -75 & -95 & -91 \\
\hline 611236 & 4798933 & Pad Piez & -4 & -9 & -44 & -37 & -47 & -55 & -49 \\
\hline 611602 & 4798869 & Cabin Piez & -29 & -35 & -58 & -68 & -99 & -109 & -92 \\
\hline 611537 & 4798745 & N Chan Piez & ni & ni & ni & -51 & -78 & -87 & -51 \\
\hline 611656 & 4798232 & SW Piez & -42 & -57 & -87 & -98 & -118 & -133 & -120 \\
\hline 612239 & 4798209 & SE Piez & -12 & -28 & -50 & -81 & -129 & $\operatorname{dry}(-161)$ & -158 \\
\hline 612218 & 4798560 & Eastbank Piez & ni & ni & -28 & -50 & -92 & & -96 \\
\hline 612145 & 4798482 & Nest Shallow & ni & ni & -36 & $\operatorname{dry}(-43)$ & $\operatorname{dry}(-43)$ & $\operatorname{dry}(-43)$ & $\operatorname{dry}(-43)$ \\
\hline 612145 & 4798482 & $\begin{array}{l}\text { Nest Deep } \\
\text { Vibracore }\end{array}$ & ni & ni & -19 & -31 & $\operatorname{dry}(-66)$ & dry(-66) & -62 \\
\hline 611865 & 4798787 & Piez & ni & ni & ni & -47 & -79 & -84 & -54 \\
\hline 611978 & 4799127 & $\begin{array}{l}\text { Cheetos Piez } \\
\text { Confluence }\end{array}$ & -194 & -213 & dry(-238) & $\operatorname{dry}(-238)$ & dry(-238) & $\operatorname{dry}(-238)$ & dry(-238) \\
\hline 611781 & 4799039 & Piez & -22 & -39 & -51 & -58 & -73 & -89 & -84 \\
\hline 612015 & 4799506 & Outlet Piez & -16 & -14 & -57 & -68 & -84 & -103 & -96 \\
\hline 611620 & 4798010 & SW S. of Road & -133 & ns & dry(-168) & $\operatorname{dry}(-168)$ & $\operatorname{dry}(-168)$ & $\operatorname{dry}(-168)$ & $\operatorname{dry}(-168)$ \\
\hline
\end{tabular}

ns = piezometer not sampled

$\mathrm{ni}=$ piezometer not yet installed

$\stackrel{\mapsto}{\triangleright}$ 
Appendix B: Discharge measurements

\begin{tabular}{|c|c|c|c|c|c|c|c|}
\hline Month & $\mathrm{m} / \mathrm{s}$ & Culvert & Pine & Cabin & $\begin{array}{l}\text { Outlet } \\
\text { Up }\end{array}$ & Outlet Low & $\begin{array}{l}\text { Outlet } \\
\text { Spr }\end{array}$ \\
\hline \multirow[t]{4}{*}{ Apr-14 } & width & 0.13 & 0.35 & & & & \\
\hline & depth & & 0.07 & & & & \\
\hline & avg vel & 0.39 & 0.06 & & & & \\
\hline & flow & 0.023 & 0.0015 & & & & \\
\hline \multirow[t]{4}{*}{ May-14 } & width & 0.11 & 0.33 & & 0.58 & 1.1 & \\
\hline & depth & & 0.06 & & 0.18 & 0.2 & \\
\hline & avg vel & 0.32 & 0.07 & & 0.15 & 0.105 & \\
\hline & flow & 0.015 & 0.0014 & & 0.015 & 0.023 & 0.0081 \\
\hline \multirow[t]{4}{*}{ Jun-14 } & width & & 0.39 & 0.94 & 0.72 & 1.24 & \\
\hline & depth & 0.11 & 0.034 & 0.048 & 0.12 & 0.14 & \\
\hline & avg vel & 0.19 & 0.11 & 0.07 & 0.12 & 0.12 & \\
\hline & flow & 0.008 & 0.0015 & 0.0032 & 0.011 & 0.021 & 0.011 \\
\hline \multirow[t]{4}{*}{ Jul-14 } & width & & & 0.05 & & & \\
\hline & depth & 0.07 & & 0.03 & & & \\
\hline & avg vel & 0.12 & & 0.41 & & & \\
\hline & flow & 0.0024 & & 0.0006 & & & \\
\hline \multirow[t]{4}{*}{ Aug-14 } & width & & 0.39 & 0.11 & 0.52 & 0.9 & \\
\hline & depth & 0.05 & 0.04 & 0.04 & 0.13 & 0.13 & \\
\hline & avg vel & 0.145 & 0.056 & 0.25 & 0.06 & 0.06 & \\
\hline & flow & 0.0021 & 0.0008 & 0.001 & 0.004 & 0.001 & 0.0033 \\
\hline \multirow[t]{4}{*}{ Sep-14 } & width & & 0.35 & 0.1 & 0.51 & 0.9 & \\
\hline & depth & 0.05 & 0.036 & 0.04 & 0.11 & 0.12 & \\
\hline & avg vel & 0.1 & 0.07 & 0.14 & 0.023 & 0.023 & \\
\hline & flow & ज़०.0012 & 0.0009 & 0.001 & 0.001 & 0.002 & 0.001 \\
\hline \multirow[t]{4}{*}{ Oct-14 } & width & & & & & & \\
\hline & depth & 0.06 & & & & & \\
\hline & avg vel & 0.4 & & & & & \\
\hline & flow & 0.0075 & & & & & \\
\hline \multirow[t]{4}{*}{ Mar-15 } & width & & & & 0.59 & 0.9 & \\
\hline & depth & 0.22 & & & 0.22 & 0.24 & \\
\hline & avg vel & 0.31 & & & 0.16 & 0.14 & \\
\hline & flow & 0.0366 & & & 0.021 & 0.031 & 0.01 \\
\hline \multirow[t]{4}{*}{ Apr-15 } & width & & & & & & \\
\hline & depth & 0.19 & & & & & \\
\hline & avg vel & 0.17 & & & & & \\
\hline & flow & 0.0168 & & & & & \\
\hline
\end{tabular}




\section{Appendix C: Relative Elevations of piezometers and springs}

\begin{tabular}{|c|c|c|c|c|}
\hline Place Name & $\begin{array}{l}\Delta \text { Elev from Ctrl } 1 \\
(\mathrm{~m})\end{array}$ & $\begin{array}{l}\text { Error } \\
(\mathrm{cm})\end{array}$ & $\begin{array}{l}\Delta \text { Elev from Ctrl } 2 \\
(\mathrm{~m})\end{array}$ & $\begin{array}{l}\text { Error } \\
\text { (cm) }\end{array}$ \\
\hline Ctrl point 1 & 0.000 & 0 & & \\
\hline 90 m Piez & 2.312 & 4.3 & & \\
\hline $60 \mathrm{~m}$ Piez & 3.048 & 5.3 & & \\
\hline 30 m Piez & 3.134 & 1.5 & & \\
\hline Mystery Hole & 2.520 & 0.7 & & \\
\hline Pad Piez & 1.057 & 2.1 & & \\
\hline PT Spr outflow & 0.585 & 3.7 & & \\
\hline Cabin Piez & -0.791 & 3.5 & & \\
\hline N Channel Piez & -0.749 & 2.7 & & \\
\hline Ctrl point 2 (vibracore) & -1.650 & 1.4 & 0.000 & 0 \\
\hline Confluence Piez & & & 0.124 & 3.6 \\
\hline Cabin Piez & & & 0.885 & 1.9 \\
\hline N Channel Piez & & & 0.901 & 0.6 \\
\hline Outlet Spring & & & -1.713 & 8.2 \\
\hline Cheetos Piez & & & 1.644 & 1.2 \\
\hline Eastbank Piez & & & 0.493 & 7.5 \\
\hline Nested East Piez & & & 0.377 & 4.1 \\
\hline SE Piez & & & 0.712 & 2.5 \\
\hline SW Piez & & & 0.412 & 6 \\
\hline Outlet Spring & & & -1.749 & 8.2 \\
\hline N. Hilltop & & & 2.926 & 9.5 \\
\hline Ex. Fence & & & -3.058 & 10.2 \\
\hline Midpoint & & & -2.786 & 10.7 \\
\hline Outlet Piez & & & -3.321 & 12.7 \\
\hline
\end{tabular}




\section{Appendix D: Stable Isotope Data}

\begin{tabular}{|c|c|c|c|c|c|c|c|c|}
\hline Sample & & & & & & & & \\
\hline Date & 17-May-14 & & 12-Jul-14 & & 19-Sep-14 & & $26-$ Oct-14 & \\
\hline Sample Location & $\mathrm{dD}(\% 0)$ & d180 $(\% 0)$ & $\mathrm{dD}(\% 0)$ & $\mathrm{d} 180(\% 0)$ & $\mathrm{dD}(\% 0)$ & $\mathrm{d} 18 \mathrm{O}(\% 0)$ & $\mathrm{dD}(\%)$ & $\mathrm{d} 180(\%)$ \\
\hline Pine tree spring & -116.61 & -15.91 & -115.87 & -15.57 & -116.67 & -15.86 & -115.78 & -15.87 \\
\hline Cabin spring & -117.45 & -16.08 & -117.55 & -16.00 & -116.39 & -15.22 & -113.51 & -15.02 \\
\hline Outlet spring & -116.61 & -16.00 & -116.77 & -15.66 & -119.44 & -16.14 & -115.96 & -15.75 \\
\hline 460 fen spring & -115.30 & -15.50 & -115.87 & -15.61 & -115.13 & -15.80 & & \\
\hline Vibracore & & & & & -86.99 & -12.11 & -114.99 & -15.62 \\
\hline Southeast & & & -112.37 & -15.26 & & & & \\
\hline Southwest & & & & & & & -114.90 & -15.61 \\
\hline Sellers Creek & -106.61 & -13.97 & -116.24 & -15.54 & -116.09 & -15.66 & -110.80 & -14.54 \\
\hline Main canal & & & & & & & -82.94 & -9.74 \\
\hline
\end{tabular}

9-Mar-15

$\mathrm{dD}(\% 0) \quad \mathrm{d} 180(\%)$

\begin{tabular}{lll} 
Cabin spring & -117.22 & -15.68 \\
Vibracore & -111.03 & -14.96 \\
Southeast & -114.77 & -15.34 \\
Southwest & -110.78 & -14.93 \\
\hline
\end{tabular}




\section{Appendix E: Core Logs}

Meadow Borings

6118034798804
611803E, 4798804 N. Round Meadow first vibracore site. Site is located $8 \mathrm{~m}$ of a N-S dry drainage ditch. There is no moisture at the surface even when stepped upon. The site forms the apex of a triangle which includes the outlet piezometer at the head of Seller Creek and the weather station. Overall pipe length is $287 \mathrm{~cm}$ and it was vibrated 273 $\mathrm{cm}$ into the ground. Compaction during coring placed the first material at $91 \mathrm{~cm}$ from top of pipe or $77 \mathrm{~cm}$ below the local ground surface. Compaction is $77 / 273=28 \%$ of total length. Water table is at $50 \mathrm{~cm}$ below local ground surfae. On July 11 in the morning the depth to water table is $47 \mathrm{~cm}$ and $50 \mathrm{~cm}$. Photos taken from top of core downward. A mechanical pencil was placed at the contact of sand versus primary pumice. Photographs taken at 2:20 p.m. Lowest about 30 to $40 \mathrm{~cm}$ of the core show increased red tints, but is light gray above this zone. Sample V-1-14: About 90 to $100 \mathrm{~cm}$ on photo tape. Sand-rich layer at top of the primary pumice. Sample V-2-14 at about $25-35 \mathrm{~cm}$. Fine-grained light tan to brown silt overlying the floated pumice zone and below the main organic-bearing zone. Upper black zone grades down to V-214 sample which persists to the settled pumice portion.

Round Meadow vibracore 3 in rush-rich part of meadow. Tips of rushes are frosted. Inside pipe depth to plug is $136 \mathrm{~cm}$ with $30 \mathrm{~cm}$ of the pipe above ground. Approximately $106 \mathrm{~cm}$ of compaction. Percent compaction is about $23 \%$ of length. Depths estimated from measuring tape spread out along length of core. This is core length rather than depth below surface. 385-374 cm: Gray-green silty clay, burrows and concretions. 374-330 cm: Bedded, brown-gray, fire horizone with charcoal at $355 \mathrm{~cm}$. Charcoal layer is $1 \mathrm{~cm}$ thick. Laminated to crudely thin bedded. Kill horizon is organic rich and $2 \mathrm{~cm}$ thick. 330-322 cm: Crystal-lithic-rich sand at base of lower pumice. $322 \mathrm{~cm}$ - orange-red zone at base of pumice. $322-230 \mathrm{~cm}$ : Lower pumice with grain size from $0.3 \mathrm{~cm}$ to 0.7 $\mathrm{cm}$ upward for pumice. Lithics and crystals are common. 230$130 \mathrm{~cm}$ : Poorly sorted, pumice up to $4 \mathrm{~cm}$ with crystal and lithic clasts present. $130-120 \mathrm{~cm}$ : Lithic and crystal-rich sand at contact with underlying primary pumice. $120-100 \mathrm{~cm}$ : Pumice, but low to no crystals and lithics - this appears to be a float pumice. 100-90 cm: Dark gray, fibrous organics. 90-55 $\mathrm{cm}$ : Brown silt, organic rich slips are black and up to $1 \mathrm{~cm}$ long. 55-40 cm: Gray-brown silt with sharp lower contact. Capped by dark gray to black organic rich but diffuse upper contact over $1 \mathrm{~cm}$ zone. 40-27 cm: Organic-rich silt. 27-0 cm: Goopy, runny gray silt. No remolded strength. Sample V3-114: lower lithic-crystal tuff. V3-2-14: Lag sand at top of pumice deposit and base of sediment section. Water temperature of

$61183247985277.1^{\circ} \mathrm{C}$ at $95 \mathrm{~cm}$ below water table. Conductivity is 49.3 
$\mu \mathrm{S} / \mathrm{cm}$. ORP $=-316.6 \mathrm{mV} . \mathrm{pH}=5.95$. Water table is $29 \mathrm{~cm}$ below local ground surface. 
Round Meadow second vibracore site. Pipe length is $470 \mathrm{~cm}$. Core extended $60 \mathrm{~cm}$ into the paleosol with the contact of the paleosol with the sandy-rich base of the lower pumice at 290 $\mathrm{cm}$. Sandy base of the upper section is $10-12 \mathrm{~cm}$ thick at about $80 \mathrm{~cm}$ below top of core (compacted). Oxidized base of the pumice is evident to about $260 \mathrm{~cm}$. A pen is included in photographs at the contact between the primary pumice and base of sand is $210-195 \mathrm{~cm}$. Sand to about $180 \mathrm{~cm}$. Floated pumice $85 \mathrm{~cm}$ from the top. Goes into fine, silty, rounded pumice upward. An organic horizon at $68 \mathrm{~cm}$ is 4 to $6 \mathrm{~cm}$ thick. Silt increases upward to about $40 \mathrm{~cm}$. Brown silt from 40 to $15 \mathrm{~cm}$ with little organic material. modern rooted zone is about 2 to $3 \mathrm{~cm}$, but the uppermost part of the layer was cut out to start the hole. Sample V2-1.14: lag sand deposit. V2-214: floated pumice layer. V2-3-14: Lower pumice unit below the lag sand. V2-4-14: Sand layer at the base of the pumice and above the kill horizon. Water temperature is $5.4^{\circ} \mathrm{C}$ at 49 $\mathrm{cm}$ below water table. Water table is $116 \mathrm{~cm}$ below top of pipe, pipe height is $69 \mathrm{~cm}$ (notes are confusing here). ORP = $-496.6 \mathrm{mV}$.

Round Meadow auger hole located on south side of meadow in open area north of the road and exclusion fence. Auger hole: $0-5 \mathrm{~cm}$ : Roots common, rooted zone 10YR22. $5-16 \mathrm{~cm}$ : Brown to dark brown, lighter color deeper. Silt with some rounded pumice. $16-39 \mathrm{~cm}$ : Resistance to augering increases - makes moist. Yellow/brown pumice is size sorted, but no crystals or lithics 10YR68. Moderately cohesive. $39-73 \mathrm{~cm}$ : Sorted to coarser pumice with no cyrstals and lithics. 73-94 $\mathrm{cm}$ : Well sorted lithic, crystal-rich sand with sparse pumice. Contact is sharp (Photography by Al Mowbray). 94-130 cm: Entered primary coarse, poorly sorted pumice with reddish mottling. 130-167 cm Sorting improves and grain size decreases to $0.7 \mathrm{~cm}$ in diamter - lower pumice - lithics and crystals. Red orange filaments woven around pumic. Sample collected in last part of hole with E.O.H. $=167 \mathrm{~cm}$. Water temperature is $9.2^{\circ} \mathrm{C}$. Conductivity is $46.0 \mu \mathrm{S} / \mathrm{cm}$. ORP $=$ $25.8 \mathrm{mV} . \mathrm{pH}=5.87$ in very turbid water. Water table is direct measured at $64 \mathrm{~cm}$ below local ground surface. 


\section{Fen Area}

Pad. Round Meadow northwest fen area. Auger hole is east of the mystery hole fen area in a rush dominated, yarrow, sedges low area. Sedges surround this site as part of the low rampart that dips away from the pad-like area. Auger log: 0$22 \mathrm{~cm}$ : Organic rich mat of roots. 22-62 cm: Dark gray to brown silty organic-rich alternating silty-organic layers. Some of the layers are sandying to about $1 \mathrm{~cm}$ thick. Some pumice layers. At $62 \mathrm{~cm}$ rooted and pumice to $1 \mathrm{~cm}$ diameter form a layer. Once past this layer water rose in the hole to ground level - about $62 \mathrm{~cm}$. $62-132 \mathrm{~cm}$ : Pumice is mostly 0.5 to 0.8 $\mathrm{cm}$ diamter with a few up to $1 \mathrm{~cm}$. Well sorted. Lithics and crystal present. Gray. From 116-132 pumice is yellow and up to $0.8 \mathrm{~cm}$. Not as well sorted. This underlies about $10 \mathrm{~cm}$ of beautiful black and white sand with little pumice or ash.Inserted 4 foot piezometer. Water temperature is $6.9^{\circ} \mathrm{C}$. Conductivity is $55.3 \mu \mathrm{s} / \mathrm{cm}$. ORP $=273.4 \mathrm{mV}$. $\mathrm{pH}=6.18$.

$30 \mathrm{~m}$. Veg is $100 \%$ cover strawberry, yarrow, monkey flower. $0-5 \mathrm{~cm}$ roots common, moderately cohesive silt, $20 \mathrm{~cm}$ silt, roots many, minor charcoal, pumice sand, pebbles, $30 \mathrm{~cm}$ gray brown granular pumice in silt, roots few. $58 \mathrm{~cm}$ yellow brown pumice to $1 \mathrm{~cm}$, moderate sort with lithics. $111 \mathrm{~cm}$ end of hole. $63 \mathrm{~cm}$ to water from pipe top, $16 \mathrm{~cm}$ pipe height. Temp 9.3, Cond 60.7, ORP -22.7, pH 6.31 
$60 \mathrm{~m}$. Veg is $100 \%$ cover juncus, mallow, buttercup, sedges. $0-5 \mathrm{~cm}$ silty peat, roots common, charcoal. $15 \mathrm{~cm}$ pumice fragments, organic rich silt. $34 \mathrm{~cm}$ layers $(1-2 \mathrm{~cm})$ of rounded pumice to $0.5 \mathrm{~cm}$ with glassy silt. $70 \mathrm{~cm}$ primary pumice $\mathrm{w} /$ few lithics, coarsening with depth. $185 \mathrm{~cm}$ red brown sand, pumice $\mathrm{w} /$ phenocrysts plentiful, rounded lithics. $238 \mathrm{~cm}$ contact btw pumice and palesol. Resistant oxidized soil, end of hole. Water at $12 \mathrm{~cm}$ bgs, Temp 10.3, Cond 44.9, ORP

$611091 \quad 4798872 \quad 259.4, \mathrm{pH} 6.03$. 6111024798853 water, Temp 9.3, Cond 47.1, ORP 240.1, pH 6.03.

$90 \mathrm{~m}$. Veg is $70 \%$ cover, strawberry, pussytoes, penstemon. $0-8 \mathrm{~cm}$ Silt, roots many, rounded pumice to $0.5 \mathrm{~cm}$, mottles in pumice, increase pumice size $\&$ angularity with depth. $100 \mathrm{~cm}$ rounded pumice, sparse silt, few mottles. $112 \mathrm{~cm}$ Sand, lithics, crystal rich, sparse pumice. $120 \mathrm{~cm}$ well sorted pumice to $0.5 \mathrm{~cm}$, greyer, sparse lithics (lower pumice). $193 \mathrm{~cm}$ strong iron staining \& cementation in pumice $10 \mathrm{~cm}$ thick layer. $240 \mathrm{~cm}$ refusal and scraping of rock. $160 \mathrm{~cm}$ bgs to

\section{Outflow Area}


Terrace SW of outlet. Round Meadow auger hole east of the outlet creek and near a rootball with coarse pumice blocks described in entry 1013. Upper part of hole is described by Brian and Jon. Pumice pieces up to 3 to $4 \mathrm{~cm}$ probably broken from alrge blocks. Largest grains size decreased downward. $107-122 \mathrm{~cm}$ : Change to about $1 \mathrm{~cm}$ for largest pumice with $0.4 \mathrm{~cm}$ and larger dominant. Small lithics and crystals. $122-173 \mathrm{~cm}$ : Well sorted pumice grains about $0.7 \mathrm{~cm}$ in diameter. At $143 \mathrm{~cm}$ strong orange on and in? pumice which remains well sorted. Intensity of orange increases with depth as grain size decreases. 173-258 c: Lithic, crystal-rich sand that is orange stained. Minor pumice content, but this varies with depth. Abrupt color change to white/gray at 226 $\mathrm{cm}$ in pumice to $0.3 \mathrm{~cm}$ with crystals and lithics. Pumice directly overlies bedrock with refusal at $258 \mathrm{~cm}$ E.O.H. No paleosol detected. Water table at $217 \mathrm{~cm}$ below ground surface rises to $213 \mathrm{~cm}$ after about 30 minutes. Water column is about $45 \mathrm{~cm}$. Water temperature is $9.3^{\circ} \mathrm{C}$ at $2 \mathrm{~cm}$ below water table. Piezometer inserted.

Same as above. $50 \%$ veg coverage, grasses, pine. $4 \mathrm{~cm}$ yellow orange sand, lithics, roots rare. $29 \mathrm{~cm}$ coarse subangular pumice to $3-5 \mathrm{~cm}$ in sand. $38 \mathrm{~cm}$ upper pumice layer. $107 \mathrm{~cm}$ middle pumice, moderate sort to $1 \mathrm{~cm} .122 \mathrm{~cm}$ lower pumice moderate to well sort to $0.5 \mathrm{~cm}$ light grey. $145 \mathrm{~cm}$ oxidized pumice, intense red/orange "Cheetos" color. $173 \mathrm{~cm}$ sand matrix with pumice, red/orange color same. $226 \mathrm{~cm}$ grey sand and pumice. $258 \mathrm{~cm}$ end of hole, refusal scrape on rock. Water in hole $217 \mathrm{~cm}$ bgs, Temp 9.3 
Confluence. Round Meadow near outflow channel at north corner of the main marsh. Auger hole is located at the apex of a wet wedge that leads down to the level of the outlet channel - a drop of approximately $2.6 \mathrm{~m}$. Auger hole: $0-5 \mathrm{~cm}$ : root mat with musk flower, short haired moss, buttercup, grasses and sedges. 5-31 cm: organic-rich silt. Dark brown to black. 31-45 $\mathrm{cm}$ : lithic-rich sand with plagiolcase, olivine, and $~ 5 \%$ pumice. 45-53 cm: Mineral-rich layer or possilbe diatomite - silt. 53$120 \mathrm{~cm}$ : Lithic-rich, crystal-rich sand with rounded pumice with largest pumice at $2 \mathrm{~cm}$. Most pumice is less than $0.5 \mathrm{~cm}$ (sample collected $85-90 \mathrm{~cm}$ ). $120-171 \mathrm{~cm}$ : mostly pumice that is less than $0.7 \mathrm{~cm}$ in diameter and moderately well sorted. E.O.H. $=171 \mathrm{~cm}$. Piezometer inserted into hole. Measurements were taken approximately 15 minutes after hole completion. Water table is $18 \mathrm{~cm}$ below local ground surface (water table is $96 \mathrm{~cm}$ below top of pipe, pipe height is $78 \mathrm{~cm}$ ). Total depth is $106 \mathrm{~cm}$ (bottom is $184 \mathrm{~cm}$ below top of pipe $-78 \mathrm{~cm}$ pipe height). Air temperature is $19.7^{\circ} \mathrm{C}$. Water column is $88 \mathrm{~cm}$. Water temperature is $8.8^{\circ} \mathrm{C}$ at $30 \mathrm{~cm}$ below water table. Conductivity is $54.4 \mu \mathrm{S} / \mathrm{cm}$ at $8 \mathrm{~cm}$ below water table. ORP $=195.2 \mathrm{mV}$.

Outlet. Round Meadow outlet area. Auger hole placed east of channel and south of FSCR 9405 . Auger hole: $0-10 \mathrm{~cm}$, roots many, silt, organic-rich. At $10 \mathrm{~cm}$ is a dinstinct charcoal layer. $10-31 \mathrm{~cm}$ - light gray, extremely fine grained - sticks in pores of skin. becomes brown-tan with depth. Could be fine grained glassy silt changing upward into diatomite. $31-81 \mathrm{~cm}-0.2 \mathrm{~cm}$ diameter pumice lapilli, well sorted, fine grained lithics. A few 1 to $2 \mathrm{~cm}$ pieces appear to be present. This raises question on whether this deposit is primary volcanic or resedimented. $81-86 \mathrm{~cm}$ - moderately sorted, largest grains to $2 \mathrm{~cm}$, brown, minor lithics, red tinted. $86-120 \mathrm{~cm}$ - fine, well sorted pumice with lithics. Hard to auger. Red brown. At $120 \mathrm{~cm}$ encounter very salt and pepper texture with abundant small lithics and crystals. 120-176 cm - sand, lithic rich, crystals are rounded. Plagioclase is prismatic but rounded. Starting at about $145 \mathrm{~cm}$ have problems with the hole. Pumice is $0.3 \mathrm{~cm}$ diameter, but appears to be slough and the sand which is believed to be present is not being recovered in the auger. Interpreted at dune sand between 120 and $176 \mathrm{~cm}$ which is E.O.H. Inserted piezometer. Temperature of water is $8.7^{\circ} \mathrm{C}$, conductivity is $43.1 \mu \mathrm{S} / \mathrm{cm}$. Water table is $32 \mathrm{~cm}$ below the local ground surface $(104 \mathrm{~cm}$ to water table from top of pipe, pipe height is $72 \mathrm{~cm}$. Total depth is $118 \mathrm{~cm}(190 \mathrm{~cm}$ from top of pipe - pipe height of $72 \mathrm{~cm}$. Water depth is at least $86 \mathrm{~cm}$. 